\title{
Element Concentrations in Growth Rings of Trees near an Abandoned Wood-Preserving Plant Site at Jackson, Tennessee
}

\author{
By THOMAS M. YANOSKY and JOHN K. CARMICHAEL
}

U.S. GEOLOGICAL SURVEY

Water-Resources InvestigationsReport 93-4223

Prepared in cooperation with the U.S. Environmental Protection Agency, Region IV, Waste Management Division, North Superfund Remedial Branch 


\section{U.S. DEPARTMENT OF THE INTERIOR BRUCE BABBITT, Secretary}

U.S. GEOLOGICAL SURVEY

ROBERT M. HIRSCH, Acting Director

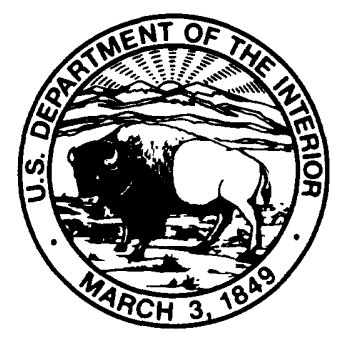

Any use of trade, product, or firm name in this report is for identification purposes only and does not constitute endorsement by the U.S. Geological Survey.

For additional information write to:

Chief, Eastern Region Branch of Regional Research 432 National Center 12201 Sunrise Valley Drive Reston, Virginia 22092
Copies of this report may be purchased from:

U.S. Geological Survey

Earth Science Information Center

Open-File Reports Section

Box 25286, MS 517

Denver Federal Center

Denver, Colorado 80225 
Abstract-1.

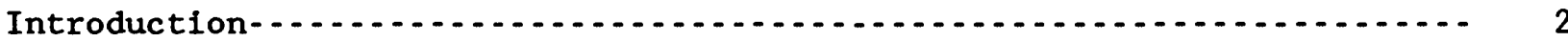

Purpose and scope

Previous tree-ring studies by the U.S. Geological Survey-......... 3

Description of study area................

Location and physical setting

Land use

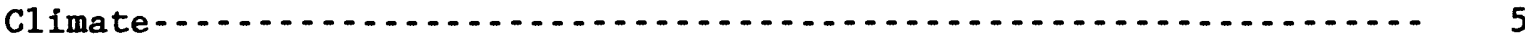

Hydrogeologic setting

History of the site and environmental conditions

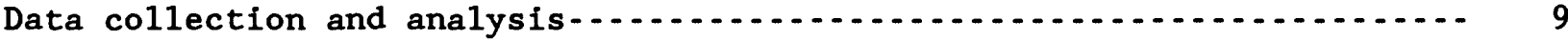

Distribution and sampling of woody vegetation................... 9

Collection and preparation of increment-core samples.............. 12

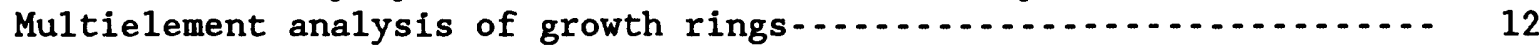

Element concentrations in growth rings of trees . . . . . .

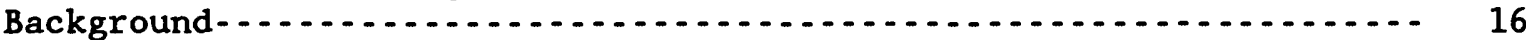

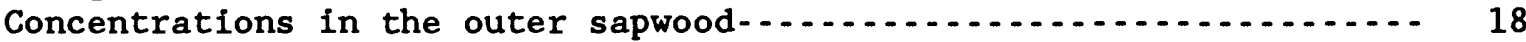

Concentrations and trends in entire growth-ring series........... 22

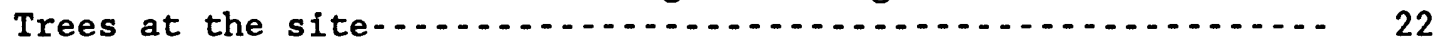

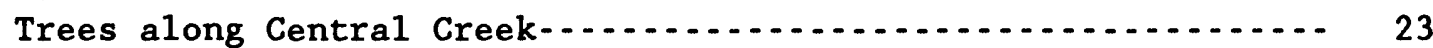

Trees along the railroad tracks

Correlations of element concentrations in tree rings

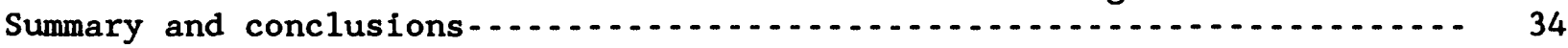

References cited- . .

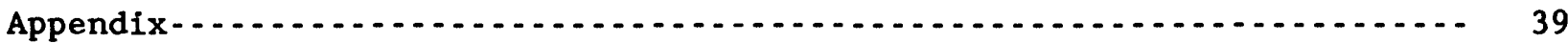

\section{FIGURES}

Figures 1-2. Maps showing:

1. location of the American Creosote Works abandoned plant site, former main process area, and estimated horizontal extent of the non-aqueous phase liquid (NAPL) plume-.......................... 4

2. study area and nine locations where tree-core samples were collected for element analysis.... 10

3. Graph showing effects of translocation on concentrations of calcium and potassium in rings of a cherrybark oak (tree CO-01 at location CC-02)-..

4-6. Graphs showing concentrations of selected elements in rings of:

4. cherrybark oaks at sampling locations CC-02 and CC-04 just east of Centra1 Creek-............ 24

5. sycamores at sampling locations CC-03 and CC-05 just west of Central Creek-................. 28

6. a willow growing just north of the railroad tracks at sampling location RR-06.......... 
7. Graph showing concentrations of potassium in selected trees sampled south of the railroad tracks at

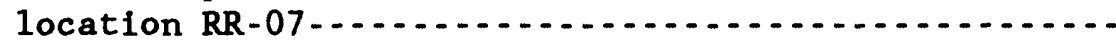

TABLES

Table 1. Post-Cretaceous geologic units underlying the American

Page

Creosote Works abandoned plant site-....................... 6

2. Sampling locations at the American Creosote Works (ACW) abandoned plant site and trees selected for element element analysis of growth rings....................... 13

3. Trees at the American Creosote Works abandoned plant site selected for element analysis ........................ 15

4. Ratios of element concentrations in trees on or near the American Creosote Works abandoned plant site compared to those of background trees of the same species.............

5. Ratios of elements (dissolved) in water sampled near the American Creosote Works abandoned plant site compared to those in background water samples . . . . . . . . . . . . .

6. Elements correlated (in brackets) within individual trees in which seven or more irradiations were performed.........

CONVERSION FACTORS AND ABBREVIATIONS

\begin{tabular}{lll}
\hline \multicolumn{1}{c}{ Multiply } & \multicolumn{1}{c}{ By } & To obtain \\
\hline liter (L) & 0.2642 & gallon \\
micrometer (um) & 0.00003937 & inch \\
millimeter (mm) & 0.03937 & inch \\
centimeter (cm) & 0.3937 & inch \\
meter (m) & 3.281 & foot \\
hectare (ha) & 2.471 & acre \\
microgram per gram (ug/g) & 1.0 & parts per million \\
milligram (mg) & 0.0000353 & ounce, avoirdupois \\
gram (g) & 0.0022 & pound \\
kilogram (kg) & 2.205 & pound \\
Degree Celsius ( $\left.{ }^{\circ} \mathrm{C}\right)$ may be converted to degree Fahrenheit ( & F) by using the \\
following equation: & &
\end{tabular}


ELEMENT CONCENTRATIONS IN GROWTH RINGS OF TREES NEAR AN ABANDONED WOOD-PRESERVING PLANT SITE AT JACKSON, TENNESSEE

By Thomas M. Yanosky and John K. Carmichael

\begin{abstract}
Multielement analysis was performed on individual annual rings of trees growing at and near an abandoned wood-preserving plant site in Jackson, Tennessee, that operated from the early 1930's until 1981. Numerous organic compounds associated with the wood-preserving process have been detected in soils, ground water, and surface water within much of the site. Tree-ring investigations were conducted prior to investigations of ground water downgradient from the site to determine if trees preserved an areal and temporal record of contaminant movement into offsite areas.
\end{abstract}

Increment cores were collected from trees on the abandoned plant site, in downgradient areas west and south of the site, and at two locations presumably unaffected by contamination from the site. Multielement analysis by protoninduced $\mathrm{X}$-ray emission was performed on 5 to 15 individual growth rings from each of 34 trees that ranged in age from about 5 to 50 years. Concentrations of 16 elements were evaluated by analyzing average concentrations within the 1987, 1989, and 1990 rings of all trees; analyzing element-concentration trends along entire core radii; and analyzing element correlations between and among trees.

Concentrations of some nutrients and trace metals were elevated in the outermost sapwood rings of some trees that grow south and southwest of the most contaminated part of the site; small trees on the main part of the site and larger trees to the west generally contained fewer rings with elevated concentrations, particularly of trace metals. Concentrations of several elements elevated in tree rings also were elevated in water samples collected from the reach of a stream that flows near the southwestern part of the site.

Multielement analysis of each ring of a willow growing along the southern boundary of the site detected extremely large concentrations of chromium, nickel, and iron in rings that formed in 1986 and thereafter. Relative increases in the concentrations of these elements also were detected in a silver maple growing next to the willow, but not in another silver maple growing 150 meters farther to the west. An oak growing in the southwestern part of the study area contained large concentrations of calcium and several trace elements, and some trees south of the abandoned site contained large concentrations of phosphorus or potassium.

Concentrations of trace metals and nutrients in some trees may be related to wood-preserving activities at the site and possibly to remedial efforts conducted during the early to mid 1980's. However, the possibility cannot be discounted that large concentrations of some elements are from sources other than the wood-preserving facility, or in part from flooding of the South Fork Forked Deer River. 


\section{INTRODUCTION}

American Creosote Works, Inc., (ACW) operated a wood-preserving facility in Jackson, Tennessee, from the early 1930's until December 1981. Creosote and pentachlorophenol (PCP) were used in the wood-preserving process. Contaminants associated with these compounds have been detected in soils, ground water, and surface water at the 27-ha facility (S\&ME, Inc., 1988). Organic contaminants include numerous polynuclear aromatic hydrocarbons (PAH); volatile organic compounds (VOC); phenolic compounds, including PCP; and nitrogen-containing heterocyclic compounds. Limited investigations of environmental conditions at the site were conducted by the State of Tennessee and the U.S. Environmental Protection Agency (USEPA) shortly after plant closure (S\&ME, Inc., 1988). The USEPA designated the abandoned plant site as a National Priorities List Superfund site in 1984, and a Remedial Investigation/Feasibility Study (RI/FS) was conducted at the site between 1986 and 1989. Because the RI/FS included only onsite areas, insufficient data were collected to assess the potential for contaminant migration to offsite areas.

In 1990, in cooperation with the North Superfund Remedial Branch, Waste Management Division, of the USEPA, Region IV, the U.S. Geological Survey (USGS) conducted an investigation to assess the presence and extent of contamination in areas beyond the site boundaries. The major emphasis of the investigation was to delineate and characterize ground-water contamination in downgradient offsite areas. A second component of the investigation included an assessment of water quality, sediment, and biological conditions of streams near the site. As part of the overall investigation, the USGS conducted multielement analysis of the annual rings of trees growing within, along, and just outside site boundaries. Because of limited access to the offsite areas, this work was conducted to determine if trees growing in areas downgradient from the ACW site could provide data on the extent of ground-water contamination prior to installation of wells in offsite areas. The tree-ring studies were conducted after completion of the surface-water component, but before completion of the ground-water component of the investigation.

\section{Purpose and Scope}

This report describes the collection and multielement analysis of core samples collected from trees growing at and adjacent to the ACW abandoned plant site and summarizes the concentrations of selected elements in individual growth rings. Element concentrations were compared within and among trees growing in known and suspected areas of contamination and in nearby areas presumably unaffected by contaminants. Concentrations of elements in tree rings also were compared to those in surface-water and stream-sediment samples collected by the USGS. The objectives of this report are to describe the methods used for the tree-ring investigation, to present results of the investigation as related to determining the extent of contamination in areas downgradient from the ACW site, and to investigate the history of contamination by examining element concentrations in successively older rings. 
The USGS has employed the multielement analysis of tree rings in conjunction with several routine investigations of contaminated ground water and surficial sediments. Vroblesky and Yanosky (1990) found that tulip trees (Liriodendron tulipifera L.) at the Aberdeen Proving Ground (APG), Maryland, preserved a chemical record of the movement of iron and chloride in groundwater plumes. They were able to estimate the velocity of these elements by determining their concentrations in a series of trees along the ground-water flow path. Similarly, Vroblesky and others (1992) found that trees at APG growing over a potassium-contaminated aquifer contained large concentrations of potassium in heartwood rings, unlike nearby trees outside the contaminated

zone. Yanosky and Vroblesky (1992) detected large concentrations of nickel in trees overgrowing nickel-contaminated aquifers in eastern Maryland, and at one site estimated the onset and rate of contaminant movement. Hupp and others (1993) examined element concentrations in trees growing in metal-contaminated sediments along the Chickahominy River near Richmond, Virginia, and found a general correlation between concentrations of nickel, zinc, and copper in rings and those in sediments. Furthermore, large concentrations of zinc in the innermost rings of some trees in this area suggest that bioavailable $z$ inc in sediments may have been substantially greater before than after 1950 .

\section{DESCRIPTION OF THE STUDY AREA}

\section{Location and Physical Setting}

The ACW abandoned plant site is located within the city of Jackson, Madison County, western Tennessee (fig. 1), and within the Gulf Coastal Plain physiographic province (Fenneman, 1938). The study area, consisting of the ACW site and offsite areas to the west and south, is located on the alluvial plains of the South Fork Forked Deer River and Central Creek (fig. 1). The South Fork Forked Deer River is the major stream draining the Jackson area, flowing generally from southeast to northwest and passing close to the southwestern corner of the site. Central Creek, a minor tributary of the river, flows generally westward from an urban area in west Jackson through a commercial and industrial area, and along part of the northern border of the site. Just west of the northwestern corner of the site, the creek turns to the southeast, flowing along the western border of the site and entering the South Fork Forked Deer River near the southwestern corner of the site.

The terrain in the study area generally is flat, except for relief provided by the stream channels and the embankment of the Seaboard Railroad along the southern boundary of the site (fig. 1). The offsite parts of the study area are swampy wooded lowlands generally unprotected by levees. The site, however, is partly protected from flooding by levees on the west and south. Land-surface altitudes range from about $103.6 \mathrm{~m}$ above sea level along the South Fork Forked Deer River to about $106.7 \mathrm{~m}$ near the northeast corner of the site. Including relief provided by the stream channels, maximum relief in the study area is about $4.6 \mathrm{~m}$. The altitude of the 100 -year flood on the South Fork Forked Deer River in the study area is about $106 \mathrm{~m}$ above sea leve1 (S\&ME, Inc., 1988). 
TENNESSEE

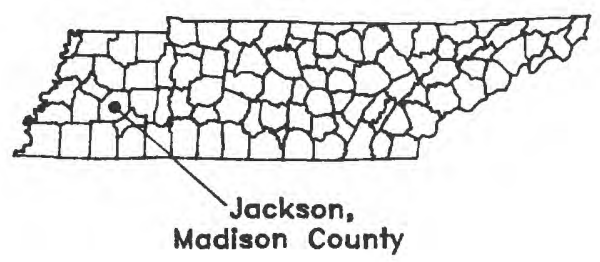

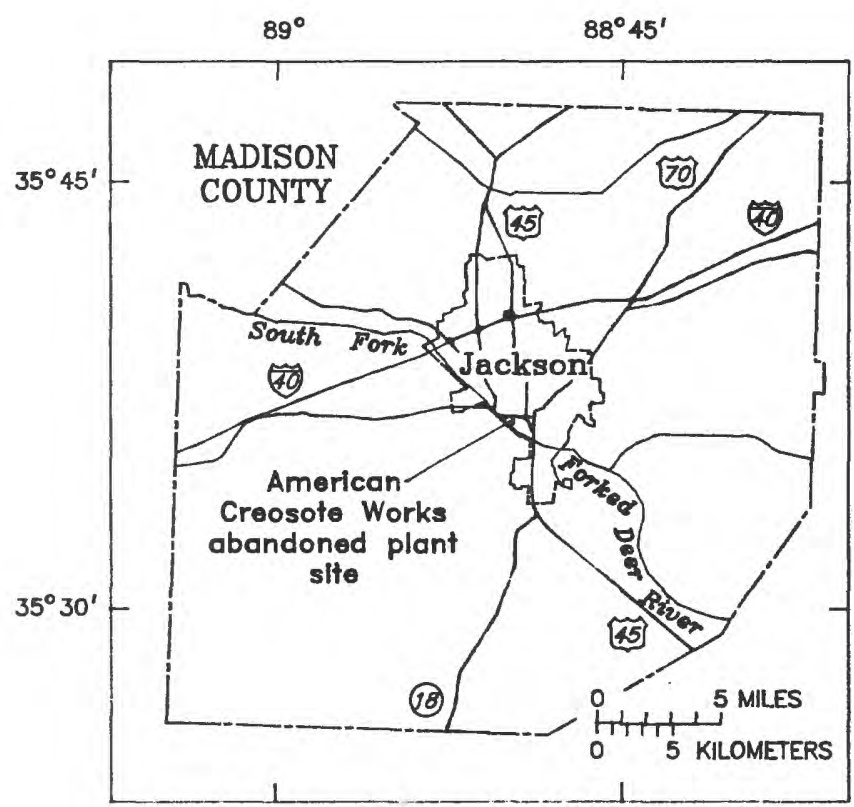

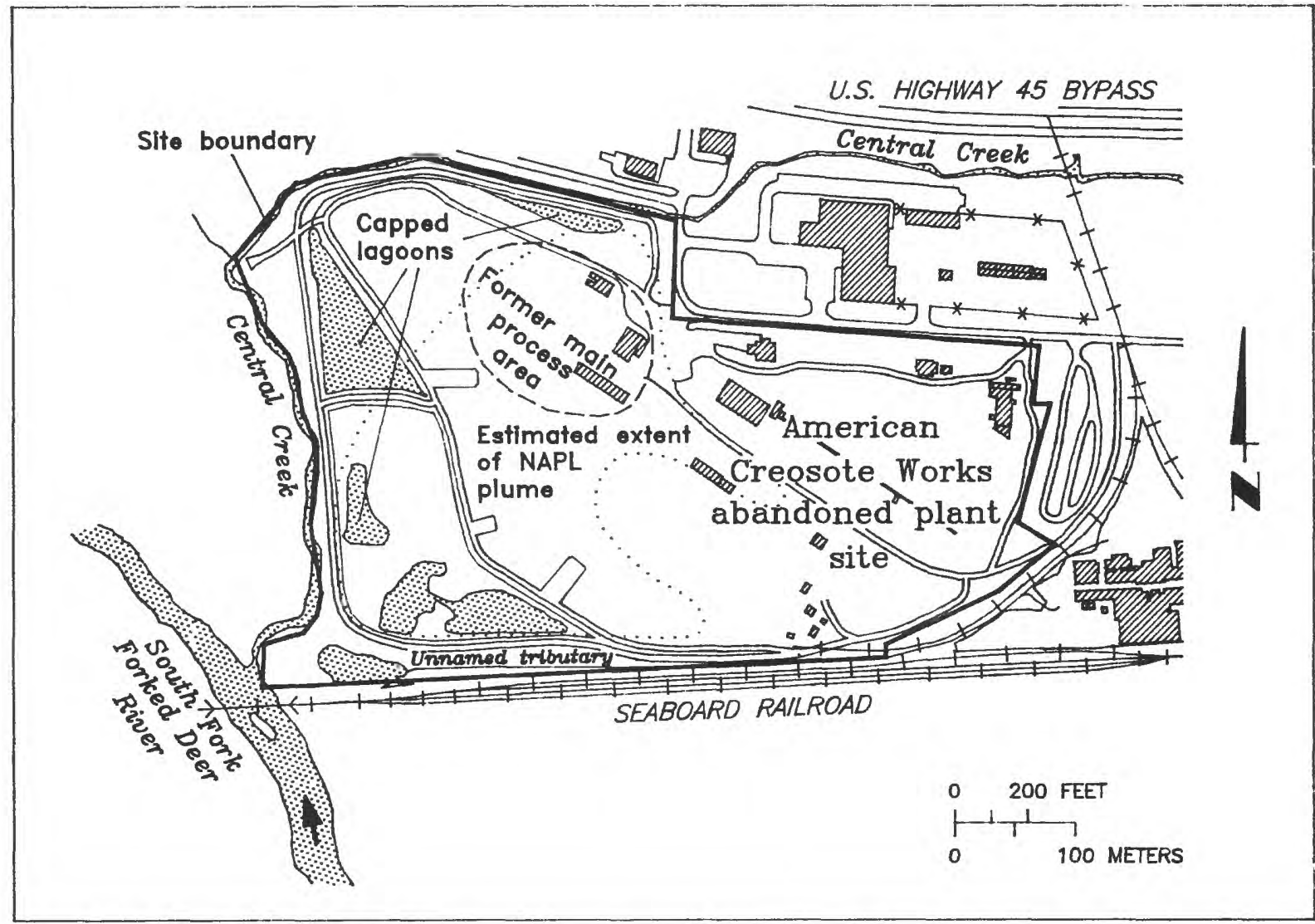

Base modified from S\&ME, Inc., 1988

Figure 1. Location of the American Creosote Works abandoned wood-preserving plant site, former main process area, and estimated horizontal extent of the non-aqueous phase liquid (NAPL) plume. 
Land use in the study area consists primarily of the ACW abandoned plant site and forested lowlands to the west and south. Areas to the north and east of the study area are used primarily for industrial/commercial purposes. Although the ACW property was cleared and maintained during its operational history, the grounds are now overgrown with grasses, scrub vegetation and young deciduous trees; only the former main process area of the facility still remains relatively free of vegetation. The offsite areas south and west of the site support hardwood forests in bottomlands of the South Fork Forked Deer River valley and presently are used as a source of lumber. The only other activity in the offsite part of the study area is maintenance of a city of Jackson utilities right-of-way that traverses the area from east to west, north of the South Fork Forked Deer River, providing vehicular access to this part of the study area.

\section{Climate}

Climate in the study area is temperate with moderately cold winters and warm humid summers. Climatic data collected at the University of Tennessee Agricultural Experiment Station about $1.5 \mathrm{~km}$ northwest of the site show that average monthly temperatures for the period of record (1961-90) ranged from $2.8^{\circ} \mathrm{C}$ in January to about $26.1^{\circ} \mathrm{C}$ in July and August (National Oceanographic and Atmospheric Administration, 1991). Precipitation averaged about $19.7 \mathrm{~cm}$ annually, with April and October being the wettest and driest months, respectively.

\section{Hydrogeologic Setting}

Soils and shallow subsurface geologic materials in the study area are derived from Quaternary-age alluvial deposits of the South Fork Forked Deer River and Central Creek, ranging in thickness from about 9 to $12 \mathrm{~m}$. Soils to depths of $2 \mathrm{~m}$ in undisturbed areas adjacent to the site are silt-loam complexes with gentle slopes, poor to moderate drainage, and high available water capacities. These soils are strongly to very strongly acidic and contain medium to low concentrations of phosphorus and potassium (Brown and others, 1978). Near-surface soils within most of the abandoned plant site are an urban land complex (S\&ME, Inc., 1988) overlain to depths of about $5 \mathrm{~m}$ by alluvial silts and clays. Because of relatively low permeability, these materials, together with the upper soils, locally serve as an upper confining or semiconfining unit for the water table. The lower 3 to $5 \mathrm{~m}$ of the alluvial deposits consist of fine to coarse sand with some gravel lenses. The base of the alluvial deposits is difficult to delineate because sand in the lower part unconformably overlies sand in the upper part of the Fort Pillow Sand of Tertiary age (Parks and others, 1993). Although the focus of the tree-ring investigation is primarily on conditions in the shallow (1-3 m) subsurface, a stratigraphic column of the alluvium and deeper geologic units is presented in table 1 . 
Table 1. Post-Cretaceous geologic units underlying the American Creosote Works abandoned plant site at Jackson, Tennessee

[Compiled from lithologic and geophysical logs of test holes drilled at the site and at the University of Tennessee Agricultural Experiment Station 1 1/2 miles northwest, and reports by Schneider and Blankenship (1950), Milhous (1959), Parks (1968), Russell and Parks (1975), and Parks and Carmichael (1989)]

\begin{tabular}{|c|c|c|c|c|c|}
\hline System & Series & Group & Stratigraphic unit & $\begin{array}{l}\text { Thickness } \\
\text { (in meters) }\end{array}$ & Lithology \\
\hline Quaternary & $\begin{array}{l}\text { Holocene } \\
\text { and } \\
\text { Pleistocene }\end{array}$ & & $\begin{array}{c}\text { Alluvium } \\
\text { (Alluvial aquifer) }\end{array}$ & $9-12$ & $\begin{array}{l}\text { Sand, silt, clay, and minor gravel. } \\
\text { Underlies the alluvial plain of } \\
\text { the South Fork Forked Deer } \\
\text { River. Upper part consists of } \\
\text { clay, silt, and fine sand; lower } \\
\text { part consists of fine to coarse } \\
\text { sand containing some gravel. }\end{array}$ \\
\hline \multirow{4}{*}{ Tertiary } & 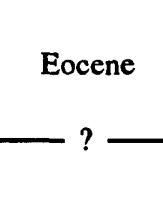 & \multirow{2}{*}{ Wilcox } & $\begin{array}{l}\text { Fort Pillow Sand } \\
\text { (Fort Pillow aquifer) }\end{array}$ & $27-41$ & $\begin{array}{l}\text { Sand, silt, clay, and minor lignite. } \\
\text { Consists of lenses of medium to } \\
\text { coarse, and fine to medium sand } \\
\text { and lenses of silt and clay at } \\
\text { various horizons. }\end{array}$ \\
\hline & \multirow{3}{*}{ Paleocene } & & $\begin{array}{l}\text { Old Breastworks } \\
\text { Formation }\end{array}$ & $0-11$ & $\begin{array}{l}\text { Sand, silt, clay, and lignite. } \\
\text { Consists of fine to medium, and } \\
\text { very fine to fine sand with } \\
\text { lenses of silt, clay, and lignite. }\end{array}$ \\
\hline & & \multirow[t]{2}{*}{ Midway } & Porters Creek Clay & 53 & $\begin{array}{l}\text { Clay and minor sand. Consists of } \\
\text { a widespread and thick body of } \\
\text { clay with some interbeds of fine } \\
\text { sand. Locally contains thin beds } \\
\text { of claystone in upper part. } \\
\text { Serves as the principal confining } \\
\text { layer separating the Fort Pillow } \\
\text { aquifer from the McNairy aquifer. }\end{array}$ \\
\hline & & & Clayton Formation & 12 & $\begin{array}{l}\text { Clay, silt, and sand. Overlies the } \\
\text { Owl Creek Formation and the } \\
\text { McNairy Sand of Cretaceous age. }\end{array}$ \\
\hline
\end{tabular}


Shallow ground water in the study area occurs under water-table or confined to semiconfined conditions, depending on the local amount of silt and clay in upper parts of the alluvium. Where unconfined, the water table generally occurs at depths of less than $3 \mathrm{~m}$ below land surface throughout the year, but may rise nearly to land surface in areas of lower elevation during wet periods. Where the upper parts of the alluvium locally act as a confining unit, ground water may be encountered at depths of 4.5 to $6 \mathrm{~m}$ below land surface, but will rise to within $1 \mathrm{~m}$ of ground surface in an open borehole or we11. Except in the northern and northeastern parts of the study area, slight increases in head occur with increasing depth beneath the alluvium, indicating an upward gradient and discharge of ground water to the alluvium and South Fork Forked Deer River from deeper zones. In the north and northeastern sections of the study area, a slight reversal in heads between shallow and deeper zones exists, suggesting downward movement of water from the alluvium. Generally, however, ground water in the alluvium moves horizontally from northeast to southwest under a low gradient to discharge to the South Fork Forked Deer River and Central Creek. Ground-water velocity in the alluvium beneath the ACW site was estimated to be about $13.5 \mathrm{~m} / \mathrm{yr}$ from work conducted during the RI/FS (S\&ME, Inc., 1988). Except for one well at an industrial facility immediately east of the site, ground water in the alluvium is unused in the study area.

\section{HISTORY OF THE SITE AND ENVIRONMENTAL CONDITIONS}

Prior to 1973, untreated process wastewater from the ACW facility was discharged directly into Central Creek (S\&ME, Inc., 1988). Up until this time, Central Creek and the South Fork Forked Deer River also received potentially contaminated runoff from the site, and flood waters from the river occasionally inundated parts of the facility. In 1973, a levee was constructed along Central Creek and the southern boundary of the property to reduce potential flooding and to prevent site runoff from discharging into the South Fork Forked Deer River and Central Creek. During levee construction, soil borrow pits were converted to storage lagoons for contaminated waste liquids. In 1974-75, a wastewater treatment system was installed and remained in operation until the facility closed in December 1981. In November 1981, four shallow wells were installed along and inside the site boundary to monitor potential ground-water contamination.

An RI/FS report prepared for the USEPA summarizes the history of response actions after the facility closed in 1981 (S\&ME, Inc., 1988). Between June 1982 and May 1983, several site inspections and sampling programs confirmed that sludge, surface solls, lagoon waters, and shallow ground water south and west of the lagoons were contaminated with organic compounds associated with creosote and PCP. In May 1983, emergency remedial actions were implemented to store approximately 190,000 L of impounded untreatable liquids in onsite tanks. Additionally, at least $30,000 \mathrm{~m}^{3}$ of sludges were placed in onsite lagoons in northern, northwestern and southwestern parts of the site, stabilized with lime kiln dust, and capped with clay.

The site was designated a National Priority List Superfund site in April 1984. In February 1985, leaking onsite tanks containing an estimated 38,000-57,000 L of PCP-contaminated water were repaired. During the summer of 1986, an estimated $340,000 \mathrm{~L}$ of contaminated liquids were lost from storage 
tanks as a result of vandalism. The RI/FS was initiated in 1986, with the final phase completed in early 1989. Also in April 1986, additional work was conducted to treat remaining liquids stored in onsite tanks. In July 1989, the USEPA initiated further surface cleanup action, including collection and treatment of remaining contaminated soil, liquids, and sludges stored onsite in tanks and removal for offsite incineration; treatment and discharge of wastewater generated during remedial activities to the South Fork Forked Deer River and Central Creek; demolition and disposal of most buildings, tanks, and other onsite structures; and restriction of access to the site. In January 1990 , the USGS investigation of offsite ground- and surface-water contamination was initiated.

Results from the RI/FS show that soil, ground water, surface water, and stream sediments at the site are degraded by organic compounds associated with wood-preserving wastes (S\&ME, Inc., 1988). Contaminated soils extend over approximately 90 percent of the facility, particularly near the former main process area and lagoons (fig. 1). Depth of soil contamination in most areas generally is less than $2 \mathrm{~m}$, but exceeds $5 \mathrm{~m}$ in some areas. Onsite organic ground-water contamination consists of a dense, non-aqueous phase liquid (NAPL) plume of PCP and creosote and an aqueous-phase plume of more soluble waste constituents. The vertical and horizontal extent of onsite ground-water contamination is not known precisely owing to an insufficient number of monitoring wells. However, data from the RI/FS and subsurface sampling conducted as part of the USGS investigation indicate that ground water contamination by the NAPL plume occurs beneath most of the western part of the site (fig. 1) and to depths of about $11 \mathrm{~m}$. Vertically, constituents associated with the aqueous-phase plume may be present to depths of $41 \mathrm{~m}$ in the northwest and southwest corners of the site (S\&ME, Inc., 1988; Parks and others, 1993). The aqueous plume may extend horizontally beyond the denser NAPL and may have migrated beyond the western and southern boundaries of the facility.

Although sampling programs conducted to date primarily have concentrated on organic contaminants, several trace inorganic constituents also have been identified in soils and water at the site (S\&ME, Inc., 1988). Arsenic, barium, cadmium, chromium, lead, and mercury were detected during the RI/FS in onsite soils in somewhat elevated concentrations; however, only cadmium and chromium were detected in ground water samples from several shallow onsite wells in concentrations slightly in excess of Primary Maximum Contaminant Levels for drinking water. Iron concentrations in soil also are sufficiently large to cause concentrations in ground water in several onsite areas to greatly exceed Secondary Maximum Contaminant Levels for drinking water. Concentrations of iron in soil and ground water seem to be influenced by the presence of organic contaminants because soil samples that contained the largest concentrations of iron also contained the largest concentrations of organic contaminants (S\&ME, Inc., 1988). Geochemical and microbial transformations of organic contaminants along the ground-water flowpath would be expected to mobilize redox-reactive constituents (Mattraw and Franks, 1986). Investigations at an abandoned wood-preserving plant site in Pensacola, Florida, found that anaerobic leachate in ground water increased the concentrations of iron, sulfate, and manganese, and, further, that concentrations of calcium, magnesium, and potassium increased in the contaminated aquifer possibly as a result of ion exchange or weathering of clays (Baedecker and Lindsay, 1986). 
Only a few samples of surface waters and stream sediments were analyzed during the RI/FS; thus, interpretation of these data is limited. In general, concentrations of contaminants in these samples were much smaller than those in soils and ground water and seem to be related to contaminants sorbed to sediment rather than the dissolved phase (S\&ME, Inc., 1988). As part of the current investigation, the USGS performed chemical analyses of surface-water and stream-sediment samples collected from Central Creek and the South Fork Forked Deer River, and from background locations on two nearby streams upgradient of the onsite area of contamination (Bradfield and others, 1993). Results of these samples confirm that Central Creek and the adjoining reach of the South Fork Forked Deer River downgradient from the site have been affected adversely by accumulation of wood-preserving waste constituents. In addition, dissolved concentrations of sulfate, magnesium, chloride, potassium, calcium, manganese, iron, zinc, barium and strontium were greater in water samples from Central Creek and water ponded on top of the clay-capped lagoon in the southwestern corner of the site than in those from the two background streams and the South Fork Forked Deer River. Furthermore, concentrations of calcium, chloride, barium, iron, manganese, and zinc were greater near the mouth of Central Creek than in sampling locations upstream, suggesting that a source for these constituents may be discharge from the site into Central Creek. Additionally, concentrations of calcium, magnesium, potassium, chloride, sulfate, iron, strontium, and aluminum were greater in water samples from the top of the large lagoon than in those from the two background streams.

\section{DATA COLLECTION AND ANALYSIS}

Collection and analysis of tree cores were conducted in two phases. Field work for phase I was conducted in November 1990; cores were collected from trees at four locations downgradient from the site, at one location near the former main processing area of the site, and at one background location presumably unaffected by contamination from the site. Proton-induced X-ray emission (PIXE) was used to perform multielement analysis of 108 individual rings from 15 trees. The second phase was initiated in October 1991 to collect core samples from trees at two additional downgradient locations and at an additional background location; additional trees also were sampled from some of the original phase-I locations. Analysis of 213 individual rings from 19 trees was performed during phase II. A more detailed description of the sampling, preparation, and analytical methods is presented in the following sections.

\section{Distribution and Sampling of Woody Vegetation}

Trees growing near the former main process area of the plant (sampling location AS-01; fig. 2) are primarily sycamore (Platanus occidentalis L.), willow (Salix L.), and cottonwood (Populus deltoides Bartr.) that began growth in the middle $1980^{\prime} \mathrm{s}$. A sparse woods grow along much of the western boundary of the site between Central Creek and the levee constructed in 1973, with the oldest trees growing along the stream. The species composition is similar to that at location AS-01, although silver maple (Acer saccharinum L.), black locust (Robinia pseudoacacia L.), and cherrybark oak (Quercus falcata var. pagodaefolia E11.) also are common. Two sampling locations (CC-02 and CC-03) 


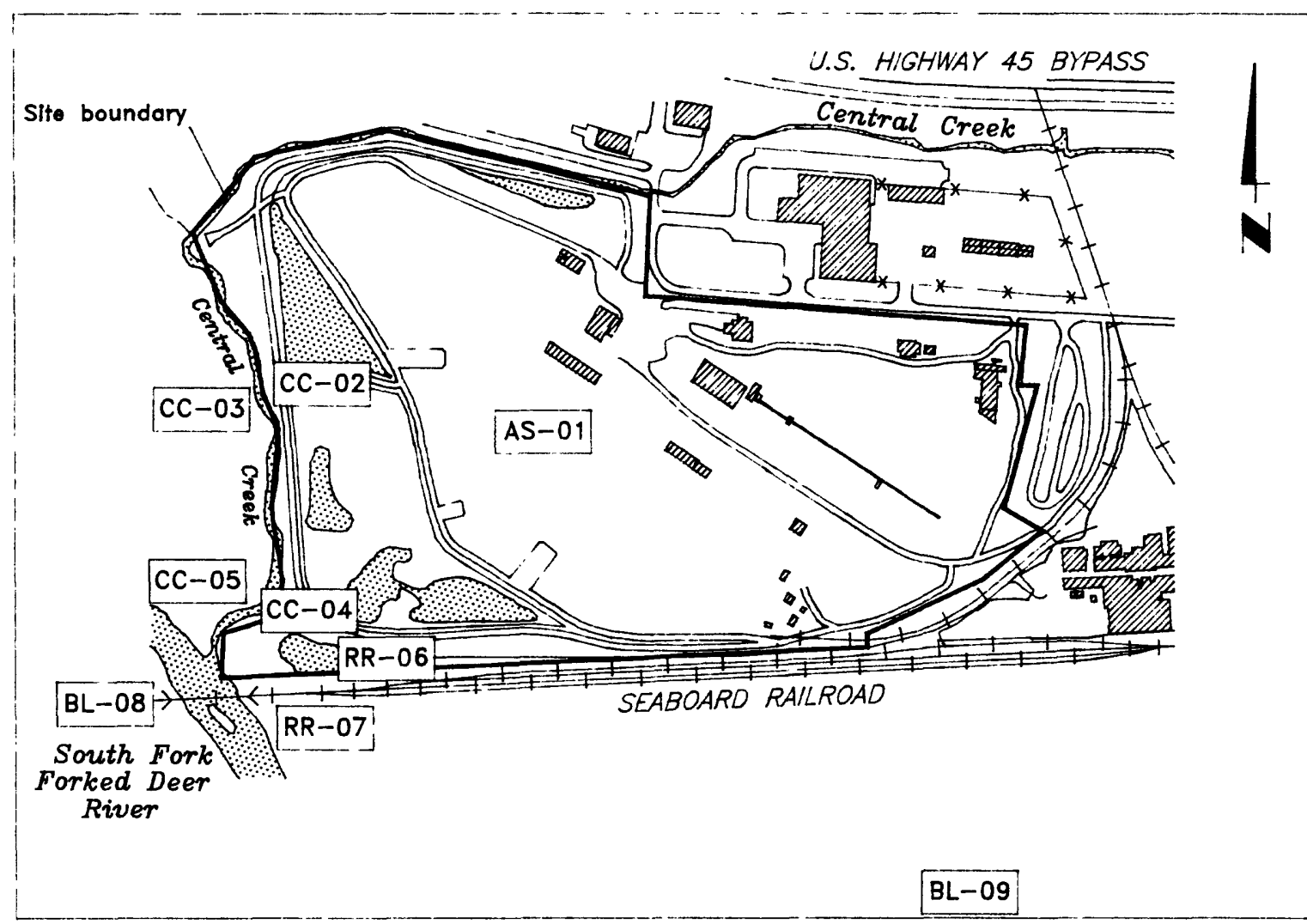

Bose modified from S\&ME, Inc., 1988

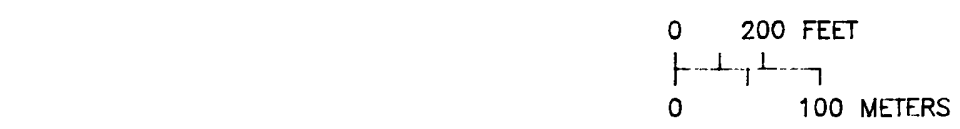

EXPLANATTON

RR-07 TREE-CORE SAMPLING LOCATION

Figure 2. Study area and nine locations where tree-core samples were collected for element analysis. 
in the northwestern part of the study area are just east and west, respectively, of Central Creek (fig. 2). Location CC-03 is just outside the site boundary and supports a forest of green ash (Fraxinus pennsylcanica Marsh.), sycamore, and silver maple; the largest trees have trunk diameters at breast height that range from 30 to $60 \mathrm{~cm}$ and ages that range from 20 to 50 years.

Two sampling locations (CC-04 and CC-05) are in the southwestern corner of the study area just east and west, respectively, of Central Creek near its confluence with the South Fork Forked Deer River (fig. 2). Location CC-04 marks the southernmost extent of vegetation along the eastern edge of Central Creek, and is bordered to the south by an open area about $40 \mathrm{~m}$ in width. It appears that woody vegetation at one time extended across the open area to the railroad tracks; a few silver maples remain just north of the tracks and within about $75 \mathrm{~m}$ from the river. Some trees in this general vicinity exhibit trunk scars apparently caused by heavy machinery used to construct a drainage ditch that carries runoff ponded on top of the southwestern-most lagoon (fig. 1) through the open area and into the South Fork Forked Deer River. Similarly, the roots of some large trees bordering the open area are exposed to depths of about $1.5 \mathrm{~m}$. A cluster of monitoring wells installed for the RI/FS is located in the open area just southwest of the levee. Trees at location CC-04 near the open area apparently are directly along the flowpath of ground and surface waters moving from the western part of the site. Trees at this sampling location are in a known area of ground-water contamination (Parks and others, 1993) and also are near the reach of Central Creek where elevated concentrations of organic and inorganic constituents were detected in surface-water and stream-sediment samples (Bradfield and others, 1993). Cherrybark oak and silver maple predominate.

Trees at location CC-05 (fig. 2) are similar in size, age, and species composition to those at location $\mathrm{CC}-03$. Willow is generally uncommon. Unlike at location CC-03, however, the surface at location CC-05 is inundated periodically by floodwaters of the South Fork Forked Deer River.

At sampling location RR-06 (fig. 2), a narrow swath of willow, sycamore, red maple (Acer rubrum L.), and silver maple extends from the South Fork Forked Deer River along and just north of the railroad tracks. This area receives drainage from eastern parts of the site along a small unnamed tributary that flows westward parallel to the railroad tracks (fig. 1). Except for an occasional older silver maple near the South Fork Forked Deer River, all trees at this location apparently have become established since the middle 1970 's.

Sampling location RR-07 is south of the railroad tracks and just east of the South Fork Forked Deer River (fig. 2). The forest here is similar to that west of Central Creek but supports willow oak (Quercus phellos L.) rather than cherrybark oak. The age of trees sampled from this area ranged from 20 to 50 years. This was the most intensively sampled location because it is outside the site boundary and along the flowpath of ground water from the site. Accordingly, samples were collected from nine trees that grow within about 50 to $150 \mathrm{~m}$ south of the railroad tracks. No trees of comparable size or age grow at location RR-06 directly opposite this transect on the northern side of the railroad tracks. 
Trees were sampled at two background locations believed to be unaffected by onsite contamination. Location BL-08 is about $300 \mathrm{~m}$ south of the railroad tracks and $100 \mathrm{~m}$ west of the South Fork Forked Deer River; location BL-09 is about $500 \mathrm{~m}$ southeast of RR-07 (fig. 2). Trees are generally older and larger at location BL-08 than at location BL-09. Sycamore, silver maple, and willow oak were sampled at each location; an ash was sampled at location BL-08 and a willow was sampled at location BL-09.

No single species grows at all sampling locations and all sampled trees began growth after operations at the facility began. The size and age of trees presumably are related to local disturbance. The kinds and number of trees from which increment cores were collected during both phases of the study are summarized in table 2 .

\section{Collection and Preparation of Increment-Core Samples}

Increment corings were collected from tree trunks at breast height with a teflon-coated borer and placed to air dry in paper drinking straws. Two cores were collected from each tree. The first core was stored for multielement analysis and the second was sanded and polished. Rings were measured to the nearest $0.01 \mathrm{~mm}$ and crossdated (Phipps, 1985) to ensure that the correct year was assigned to each ring. Sanded cores were used to confirm the location of ring boundaries in cores prepared for multielement analysis. This method was particularly useful for detecting the false and discontinuous rings sometimes encountered in diffuse-porous species such as cottonwood, silver maple, sycamore, and willow.

\section{Multielement Analysis of Growth Rings}

Cores were mounted in Lucite holders and shaved to a flat surface with a stainless-steel scalpel. Multielement analysis of selected individual rings was performed by PIXE according to the methods of Legge and others (1984). Each ring subjected to proton bombardment emits characteristic $X$-rays from which constituent-element concentrations can be measured with 95 percent confidence. The width of the beam was adjusted to the width of individual rings; for each core, a set of four different beams was chosen that ranged in width from 1.0 to $5.5 \mathrm{~mm}$, although the tilting of ring boundaries sometimes precluded a precise fitting. The length of the beam was 1.5 or $2.0 \mathrm{~mm}$ along the short axis of the core and penetrated its surface to a depth of approximately $100 \mathrm{um}$. Efforts were taken to prevent overlap of the beam onto adjacent rings, although in a few cases two or more very narrow rings were analyzed simultaneously by one irradiation.

In total, 321 irradiations were performed on 34 trees representing seven species. The 1987, 1989, and 1990 rings were analyzed in all trees. The 1988 ring was not analyzed because its width in some trees was less than 1.0 $\mathrm{mm}$. The 1972, 1976, 1978 and 1982 rings also were analyzed in most samples, as were other even-numbered rings in some older trees. Irradiations were performed on each ring of the willow from location RR-06 and on each ring of trees sampled at location AS-01. A summary by site of the species, number, and yearly range of irradiated rings is given in table 3 . 
Table 2. Sampling locations at the American Creosote Works (ACW) abandoned plant site and trees selected for element analysis of growth rings

\begin{tabular}{|c|c|c|c|}
\hline $\begin{array}{l}\text { Sampling } \\
\text { location }\end{array}$ & $\begin{array}{l}\text { Code and } \\
\text { number }\end{array}$ & $\begin{array}{l}\text { Trees } \\
\text { sampled }\end{array}$ & Comments \\
\hline Active site & AS -01 & $\begin{array}{l}\text { Cottonwood } \\
\text { Sycamore } \\
\text { Willow (2) }\end{array}$ & $\begin{array}{l}\text { Near former main process } \\
\text { area of ACW site; trees } \\
\text { began growth after } 1981 \text {. }\end{array}$ \\
\hline Central Creek & $\mathrm{CC}-02$ & $\begin{array}{l}\text { Cherrybark oak } \\
\text { Sycamore } \\
\text { Willow }\end{array}$ & $\begin{array}{l}\text { Just east of Central Creek } \\
\text { along northwestern } \\
\text { boundary of ACW site. }\end{array}$ \\
\hline Central Creek & CC-03 & $\begin{array}{l}\text { Green ash } \\
\text { Sycamore }\end{array}$ & $\begin{array}{l}\text { Just west of Central Creek } \\
\text { along northwestern } \\
\text { boundary of ACW site. }\end{array}$ \\
\hline Central Creek & CC- 04 & $\begin{array}{l}\text { Cherrybark oak } \\
\text { Silver maple } \\
\text { Willow }\end{array}$ & $\begin{array}{l}\text { Just east of Central Creek } \\
\text { along southwestern } \\
\text { boundary of ACW site. }\end{array}$ \\
\hline Central Creek & CC -05 & $\begin{array}{l}\text { Green ash } \\
\text { Sycamore }\end{array}$ & $\begin{array}{l}\text { Just west of Central Creek } \\
\text { along southwestern } \\
\text { boundary of ACW site. }\end{array}$ \\
\hline Railroad tracks & $R R-06$ & $\begin{array}{l}\text { Silver maple (2) } \\
\text { Willow }\end{array}$ & $\begin{array}{l}\text { Just north of railroad } \\
\text { tracks along southern } \\
\text { boundary of ACW site. }\end{array}$ \\
\hline Railroad tracks & RR -07 & $\begin{array}{l}\text { Green ash (3) } \\
\text { Sycamore (3) } \\
\text { Silver maple (2) } \\
\text { Willow oak }\end{array}$ & $\begin{array}{l}\text { Just south of railroad } \\
\text { tracks along southern } \\
\text { boundary of ACW site. }\end{array}$ \\
\hline $\begin{array}{l}\text { South Fork } \\
\text { Forked Deer } \\
\text { River }\end{array}$ & BL-08 & $\begin{array}{l}\text { Green ash } \\
\text { Sycamore } \\
\text { Silver maple } \\
\text { Willow oak }\end{array}$ & $\begin{array}{l}\text { Background location along } \\
\text { South Fork Forked Deer } \\
\text { River southwest of ACW } \\
\text { site. }\end{array}$ \\
\hline Adjacent woods & BL-09 & $\begin{array}{l}\text { Sycamore } \\
\text { Silver maple } \\
\text { Willow } \\
\text { Willow oak }\end{array}$ & $\begin{array}{l}\text { Background location } \\
\text { southeast of ACW site. }\end{array}$ \\
\hline
\end{tabular}


Table 3. Trees at the American Creosote Works abandoned plant site selected for element analysis

LA, ash; Co, cherrybark oak; CH, cottonwood; S, sycamore; SM, silver maple; H, willow;

wo, willow oak. See table 2 for explanation of abbreviations of sampling locations.]

\begin{tabular}{|c|c|c|c|c|}
\hline $\begin{array}{l}\text { Sampling } \\
\text { location }\end{array}$ & $\begin{array}{l}\text { Tree } \\
\text { sampled }\end{array}$ & $\begin{array}{l}\text { Trunk diameter, } \\
\text { in centimeters }\end{array}$ & $\begin{array}{c}\text { Number of } \\
\text { Irradiations }\end{array}$ & $\begin{array}{l}\text { Yearly range of } \\
\text { rings Irradiated }\end{array}$ \\
\hline AS -01 & $\begin{array}{r}C W-01 \\
S-01 \\
W-01 \\
W-02\end{array}$ & $\begin{array}{l}12.8 \\
10.4 \\
19.1 \\
16.5\end{array}$ & $\begin{array}{l}5 \\
4 \\
5 \\
4\end{array}$ & $\begin{array}{l}1986-90 \\
1987-90 \\
1986-90 \\
1987-90\end{array}$ \\
\hline $\mathrm{CC}-02$ & $\begin{array}{r}C 0-01 \\
\text { SM-01 } \\
W-01\end{array}$ & $\begin{array}{l}50.8 \\
43.2 \\
16.2\end{array}$ & $\begin{array}{l}9 \\
4 \\
5\end{array}$ & $\begin{array}{l}1942-90 \\
1985-90 \\
1983-90\end{array}$ \\
\hline CC -03 & $\begin{array}{l}A-01 \\
S-01\end{array}$ & $\begin{array}{l}63.1 \\
33.3\end{array}$ & $\begin{array}{l}9 \\
9\end{array}$ & $\begin{array}{l}1972-90 \\
1972-90\end{array}$ \\
\hline CC-04 & $\begin{array}{r}C 0-01 \\
\text { SM-01 } \\
W-01\end{array}$ & $\begin{array}{l}84.5 \\
78.7 \\
33.0\end{array}$ & $\begin{array}{r}14 \\
13 \\
7\end{array}$ & $\begin{array}{l}1965-90 \\
1952-90 \\
1972-90\end{array}$ \\
\hline CC-05 & $\begin{array}{l}A-01 \\
S-01\end{array}$ & $\begin{array}{l}39.1 \\
49.0\end{array}$ & $\begin{array}{l}15 \\
15\end{array}$ & $\begin{array}{l}1948-90 \\
1948-90\end{array}$ \\
\hline RR-06 & $\begin{array}{r}\text { SM-01 } \\
\text { SM-02 } \\
W-01\end{array}$ & $\begin{array}{l}22.9 \\
64.3 \\
25.6\end{array}$ & $\begin{array}{r}7 \\
13 \\
15\end{array}$ & $\begin{array}{l}1978-90 \\
1956-90 \\
1976-90\end{array}$ \\
\hline RR-07 & $\begin{array}{r}\text { A-01 } \\
\text { A-02 } \\
\text { A-03 } \\
\text { S-01 } \\
\text { S-02 } \\
\text { S-03 } \\
\text { SM-01 } \\
\text { SM-02 } \\
\text { WO-01 }\end{array}$ & $\begin{array}{l}50.8 \\
21.6 \\
31.5 \\
29.2 \\
47.5 \\
29.5 \\
42.5 \\
53.6 \\
76.2\end{array}$ & $\begin{array}{r}15 \\
11 \\
10 \\
5 \\
7 \\
10 \\
11 \\
12 \\
6\end{array}$ & $\begin{array}{l}1948-90 \\
1964-90 \\
1948-90 \\
1976-90 \\
1968-90 \\
1968-90 \\
1964-90 \\
1952-90 \\
1972-90\end{array}$ \\
\hline BL-08 & $\begin{array}{r}A-01 \\
\text { S-01 } \\
\text { SM-01 } \\
\text { WO-01 }\end{array}$ & $\begin{array}{l}47.0 \\
41.9 \\
67.3 \\
35.1\end{array}$ & $\begin{array}{l}15 \\
15 \\
10 \\
12\end{array}$ & $\begin{array}{l}1948-90 \\
1948-90 \\
1968-90 \\
1960-90\end{array}$ \\
\hline BL-09 & $\begin{array}{r}S-01 \\
S M-01 \\
W-01 \\
W 0-01\end{array}$ & $\begin{array}{l}48.3 \\
40.6 \\
20.3 \\
61.2\end{array}$ & $\begin{array}{r}5 \\
11 \\
6 \\
7\end{array}$ & $\begin{array}{l}1976-90 \\
1964-90 \\
1976-90 \\
1972-90\end{array}$ \\
\hline
\end{tabular}


Pearson correlation coefficients were constructed to determine correlations between and among element concentrations within each tree. Correlations with Bonferroni-adjusted probabilities (Wilkinson, 1990) equal to or less than 0.05 were accepted as significant. Coefficients were not constructed if less than seven irradiations were performed on a tree, or if the concentration of an element was less than the detection limit in one-third or more of the total irradiations; if fewer than one-third of the irradiations were below the detection limit, a concentration one-half that of the detection limit was used as an estimated concentration.

Element concentrations in each tree were compared to those in other trees of the same species at that sampling location (if available), to those in different species at that location, and to those in all remaining trees, including those from background locations. Analyses were performed of (1) the average concentration of each element within rings that formed in 1987, 1989, and 1990 to infer the present extent of element availability among sampling locations; (2) element-concentration trends within all irradiated rings to investigate temporal changes in element availability; and (3) element correlations among trees to evaluate further the availability of elements at sampling locations.

Although each irradiation of wood by PIXE determined the concentrations of 15-20 elements, the following elements were considered the most 1ikely indicators of environmental alteration in this investigation:

1. Iron: Concentrations of iron in areas of known soil and ground-water contamination at the site were greater than those in nearby uncontaminated areas, and are believed to delineate the approximate spatial extent of surficial contamination (S\&ME, Inc., 1988). Additionally, dissolved concentrations of iron were elevated in water samples from the lowest reaches of Central Creek relative to nearby background streams (Bradfield and others, 1993). Iron was detected in all growth rings analyzed in this study and seemingly was not translocated across ring boundarles.

2. Silicon: Although concentrations of silicates are no greater in Central Creek than in background streams, silicon can be mobilized at near neutral $\mathrm{pH}$ levels in the presence of organic acids (Bennet and Siege1, 1987). In studies to date, ring concentrations of silicon generally vary only minimally within and among trees.

3. Chloride: The degradation of chlorinated organic compounds present in waste materials at the site may furnish chloride for uptake by trees. Concentrations of chloride were greater in water samples from Central Creek and from discharge of water ponded on top of the large lagoon than in background streams (Bradfield and others, 1993). Chloride may act as a conservative indicator of ground-water flow velocity (Vroblesky and Yanosky, 1990) but may be translocated across ring boundaries of some tree species.

4. Phosphorus and potassium: These important nutrients occur in belowaverage to average concentrations within local soil formations in the study area (Brown and others, 1978). Increased availability of potassium sometimes results in increased uptake and subsequent translocation of potassium from outer to inner rings (Vroblesky and others, 1992). Concentrations of 
phosphorus in most trees generally increase from inner to outer sapwood rings. Relative to background streams, concentrations of potassium were greater in water samples from Central Creek, the lagoon, and the unnamed tributary (Bradfield and others, 1993). Phosphorus concentrations in surface water were not determined.

5. Calcium and sulfate: Concentrations of both elements are substantially greater in water samples collected from Central Creek and the ponded water on top of the lagoon than in those from the South Fork Forked Deer River and the background streams. A possible source for calcium is lime kiln dust used during remedial efforts at the site.

The application and interpretation of ring-element studies in the present investigation are complicated by a poor understanding of the relative extent to which contaminants were transported in ground water, overland runoff, and mass movement during the construction of onsite levees and lagoons. Additionally, some of the sample locations are flooded periodically by the South Fork Forked Deer River. Trees growing on the former main process area of the site (location AS-01) are much younger and smaller than others sampled elsewhere, and it is unknown how these factors affect the uptake, transport, and subsequent storage of elements in their rings. Two background sampling locations, although probably unaffected by contamination from the site, may have received contaminants from other sources. Because trees from areas of suspected contamination were compared to background trees, contamination of background sampling locations would be expected to result in underestimates of the chemical "signal" in the other study trees.

Similarly, the enhanced concentration of elements in trees from certain locations could have resulted from increased element availability caused by railroad activities or by flooding of the South Fork Forked Deer River rather than from past wood-preserving operations at the site.

\section{ELEMENT CONCENTRATIONS IN GROWTH RINGS OF TREES}

\section{Background}

The wood of trees is composed primarily of carbon, hydrogen, oxygen, and nitrogen. Elements typically detected by PIXE include sodium, magnesium, aluminum, silicon, phosphorus, sulfur, chloride, potassium, calcium, titanium, chromium, manganese, iron, nickel, copper, zinc, barium, rubidium, strontium, and lead. Many of these elements are present as cations bound exchangeably to negative residues of mature, nonliving conducting and strengthening cells. Additionally, elements are stored within a system of vascular rays that runs lateral to the main axis of the tree. Rays remain living within a zone of rings ("sapwood") just inside the bark but are nonliving within rings to the inside of the sapwood ("heartwood"). In many trees the heartwood appears darker than the sapwood. With time, each sapwood ring is converted to heartwood as the tree continues to add new outer rings. The width of the sapwood and the number of growth rings comprising it vary among individual trees of the same species and among species (Sargent, 1926).

The element concentrations in rings presumably are related to the availability of elements during ring formation, although additional endogenous 
and exogenous factors apparently also are important (McClenahen and others, 1989; Yanosky and Vroblesky, 1992). For example, little is known about the species-dependent uptake of elements; the effects of tree size, age and yearly growth rate upon element concentrations in rings; and the degree to which elements are homogeneously distributed within localized parts of individual rings .

An important factor in the evaluation of ring-element concentrations is the potential lateral movement of elements across ring boundaries (translocation). During the conversion of innermost sapwood rings to heartwood, some elements stored in the rays are transported laterally into rays of the remaining sapwood (fig. 3). Conversely, larger concentrations of an element in heartwood than in sapwood can result from element deposition into innermost sapwood rings during their conversion to heartwood (Vroblesky and others, 1992). The heartwood/sapwood boundary seemingly is a barrier to further exchange of elements between rays of the two zones. Bondietti and others (1989) found that potassium and phosphorus were translocated from older to younger rings in a number of tree species. Completed and ongoing studies conducted by the USGS have found evidence for the translocation of potassium, phosphorus, calcium, strontium, chloride, and bromide; however, translocation of these elements seems to be species specific and, possibly, site specific. Trace metals seemingly are translocated minimally, if at all, although further investigation is suggested.

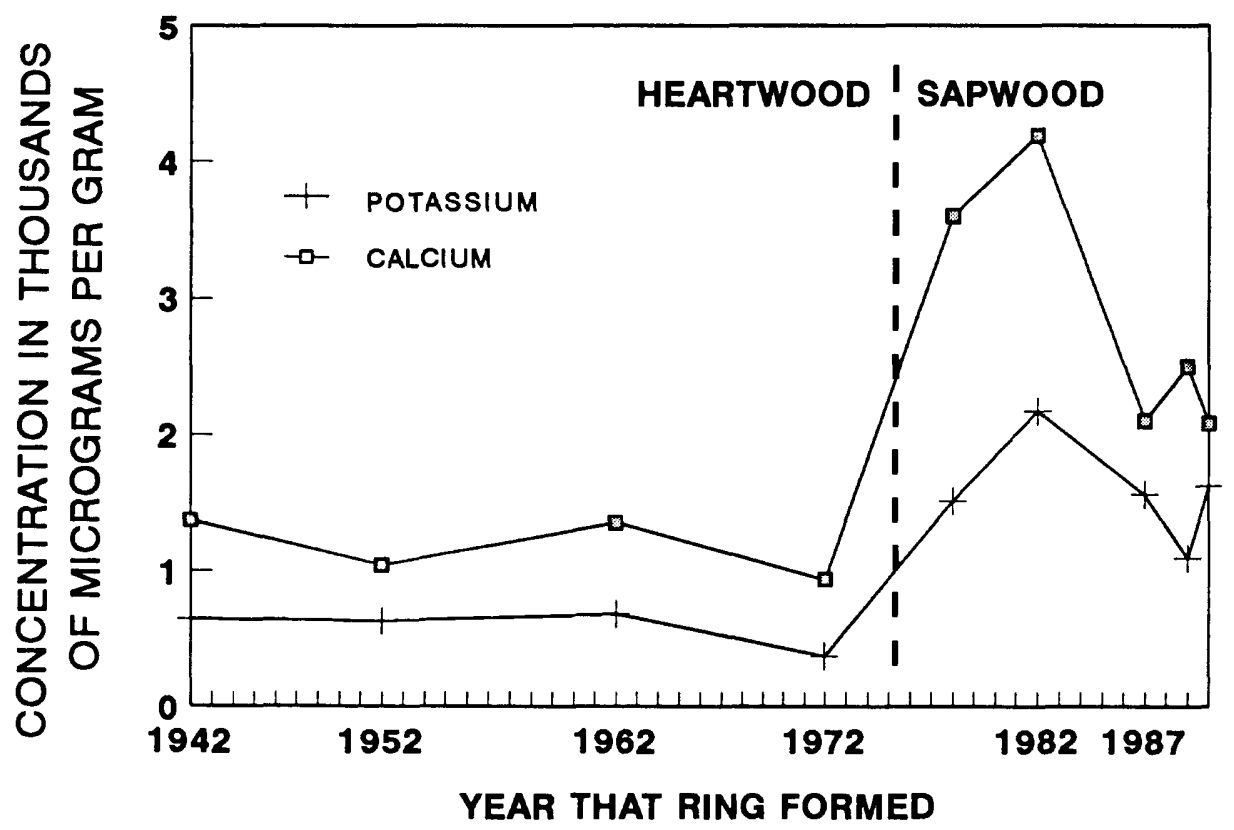

Figure 3. Effects of translocation upon concentrations of calcium and potassium in rings of a cherrybark oak (tree $\mathrm{CO}-01$ at location CC-02). Both elements are more highly concentrated in sapwood rings (1978-90) than in heartwood rings (1942-72) because of their translocation from inner to outer sapwood rings during the formation of heartwood, rather than to increased availability of these elements during the interval of sapwood growth. 
Thus, in order to conclude that concentrations of elements in rings reflect their yearly environmental availability, it must be shown that element concentrations were not the primary result of translocation (Yanosky and Vroblesky, 1992). Although this is sometimes difficult, the extent of translocational effects generally can be determined by careful inspection of element concentrations near the heartwood/sapwood boundary in all specimens of a given species. Additionally, the concentrations of some divalent cations in some trees typically decrease (Momoshima and Bondietti, 1990)) or increase gradually from inner to outer sapwood rings.

A final interpretive problem is the designation of element concentrations within an individual ring or group of consecutive rings as "elevated" relative to other rings sampled from a tree. Although element-concentration differences between and among trees of the same species can be determined by standard statistical treatments, the number of rings irradiated in this study differed greatly among trees, as did the years of ring formation and the location of the heartwood/sapwood boundary. On the basis of data gathered in all USGS studies to date, within-tree concentrations of most nutrients (calcium, phosphorus, potassium, sulfur) are less variable than those of trace elements and chloride. In some instances, large differences in nutrient concentrations result from translocation (Vroblesky and others, 1992), but a two-fold variation in ring-element concentrations was seldom detected when irradiations were performed exclusively within the heartwood or the sapwood. Accordingly, the concentration of a nutrient within a ring was considered elevated if it was twice that of other rings within or among trees. Similarly, concentrations of trace metals and chloride were considered elevated if they exceeded by 2 to 5 times those of adjacent rings, depending on the homogeneity of concentrations along the core radius.

Even though designations of elevated concentrations were not based on a precise statistical definition, most elevated concentrations clearly were outliers compared to those of remaining rings. A trend of elevated element concentrations among several adjacent rings may be a more reliable indicator of a growth response to increased element availability than is a single outlier among a uniform set of concentration data (Vroblesky and Yanosky, 1990). The only exception to this evaluation method was the comparison study of the average element concentrations within the 1987, 1989, and 1990 rings of each tree relative to its corresponding background tree(s). In this one case, an average concentration exceeding its respective background concentration by only 50 percent was considered elevated because ring number, years of formation, and designations as sapwood were constant among all trees.

\section{Concentrations in the Outer Sapwood}

The initial comparison among trees was of the average concentration of each element in rings that formed in 1987, 1989, and 1990. These three rings were analyzed in all sampled trees and $\mathbf{1 l l}$ are within the sapwood. The average concentration of each element in each tree was divided by its respective average concentration in a background tree of the same species; if two background trees were sampled, the tree with the higher concentration was selected. This provided a conservative comparison. A concentration ratio 
equaling or exceeding 1.5 was considered to reflect an environmental difference possibly related to the effects of site-specific contamination. This hypothesis was strengthened when an element greatly concentrated in tree rings also was elevated in surface waters from sampling locations along Central Creek and (or) ponded water from the lagoon.

The ratios determined by dividing the concentration of each element (excluding lead) in study trees by its respective concentration in background trees, as explained above, are listed in table 4. Element ratios equaling or exceeding 1.5 were less frequent within trees from northwestern sampling locations (AS-01, CC-02, and CC-03; fig. 2) than within trees from southwestern sampling locations (CC-04, CC-05, RR-06, RR-07; fig. 2). Without regard to specific elements, only 12 percent of element ratios in northwestern trees exceeded those in background trees by 50 percent; eight trees had two or fewer elevated concentrations, and one tree had four. The maximum ratio was 3.2. In the southwestern group, however, 26 percent of the element ratios exceeded background trees by 50 percent, including 10 trees each with four or more elevated ratios. Fourteen ratios exceeded 3.0 , and the maximum ratio was 10.9. If only species growing in northwestern- and southwestern-sample locations are compared (thus removing cottonwood and silver maple), ratios were elevated in 12 and 33 percent, respectively.

Elevated ratios of phosphorus, potassium, barium, and titanium were more frequent in southwestern than in northwestern trees. Concentration ratios exceeded 3.0 in some southwestern trees for silicon, phosphorus, potassium, chromium, iron, nickel, zinc, barium, and strontium (table 4). Elevated ratios of manganese were found exclusively in northwestern trees. The proportion of northwestern and southwestern trees with elevated ratios of sulfur, silicon, chloride, and zinc was approximately equal, although the range of ratios was greater (except for chloride) within southwestern trees (table 4).

Ratios of calcium, chromium, iron, nickel, copper, and strontium were elevated exclusively in trees sampled from southwestern parts of the study area (table 4). Each tree with elevated iron also contained elevated ratios of nickel and chromium. The willow sampled from location RR-06 contained the greatest sapwood concentrations of iron and chromium detected in this or any study conducted by the USGS; element ratios were 10.9 and 9.8 , respectively (table 4).

Although the inorganic analyses of offsite ground water were not available for use in this report, concentrations of sulfate, chloride, potassium, calcium, manganese, iron, zinc, barium, and strontium were elevated in surface-water samples from Central Creek and (or) from the ponded water on the lagoon (Bradfield and others, 1993) (table 5). The element concentrations in water samples from the reach of Central Creek that flows along the western boundary of the site generally increased toward its confluence with the South Fork Forked Deer River, suggesting that ground-water discharge from the site may be impacting lower reaches of the stream. The positive association between elevated concentrations of many elements in surface waters from this reach of Central Creek and in trees in the southwestern sampling locations strengthens the contention that trees may preserve a record of element availability at these sampling locations. 
Table 4. Ratios of element concentrations in trees on or near the American Creosote Works abandoned plant site compared to those of background trees of the same species

CRatios were calculated from the average concentrations in the 1987, 1989, and 1990 growth rings. Only ratios that equal or exceed 1.5 are included. -., ratio less than 1.5; $<$, less than; see table 2 for explanation of abbreviations of sampling locations and tree nomenclature.J

\begin{tabular}{|c|c|c|c|c|c|c|c|c|c|}
\hline $\begin{array}{l}\text { Sampling } \\
\text { location }\end{array}$ & $\begin{array}{l}\text { Tree } \\
\text { sampled }\end{array}$ & $\mathbf{s i}$ & $\mathbf{P}$ & $\mathbf{s}$ & C1 & $\mathbf{K}$ & $\mathbf{C a}$ & $\mathbf{T I}$ & $\mathrm{Cr}$ \\
\hline \multirow{4}{*}{ AS - 01} & CW-01 & - . & - - & $\star$ & - - & - - & - - & - & - \\
\hline & S-01 & - & $\cdots$ & -- & 3.2 & 1.5 & - & - & -. \\
\hline & W-01 & - & $\ldots$ & - & $\ldots$ & -. & $\ldots$ & $\cdots$ & -. \\
\hline & W-02 & 1.9 & $\cdots$ & -- & - & $\cdots$ & - & $\cdots$ & $\cdots$ \\
\hline \multirow[t]{3}{*}{ CC- 02} & $\mathrm{CO}-01^{\#}$ & - & - & -- & - & $\cdots$ & - & $\ldots$ & $\ldots$ \\
\hline & S-01 & - & $\ldots$ & -- & - & - & - & 2.7 & -. \\
\hline & W-01 & 1.7 & $\cdots$ & - & - & $\cdots$ & - & - & $\cdots$ \\
\hline \multirow[t]{2}{*}{$\mathrm{CC}-03$} & $A-01$ & - & 2.3 & 1.5 & $\ldots$ & 2.3 & $\ldots$ & $\ldots$ & $\ldots$ \\
\hline & $S-01$ & $\cdots$ & - & -- & 1.5 & -. & - & $\cdots$ & - \\
\hline \multirow[t]{3}{*}{ CC -04} & $\mathrm{CO}-01^{\#}$ & -- & - & $\cdots$ & $\ldots$ & $\cdots$ & - & $\ldots$ & $\ldots$ \\
\hline & SM-01 & - & - & -- & - & - & 1.8 & $\ldots$ & -. \\
\hline & $\mathrm{W}-01$ & 2.6 & $\cdots$ & -- & - & $\cdots$ & - & - & 3.0 \\
\hline \multirow[t]{2}{*}{ CC -05} & $A-01$ & - & 2.9 & $\cdots$ & $\cdots$ & 2.0 & -- & -- & $\cdots$ \\
\hline & S-01 & -- & - & $\cdots$ & -- & - & 1.6 & 1.7 & 2.8 \\
\hline \multirow[t]{3}{*}{$R R-06$} & SM-01 & $\ldots$ & $\ldots$ & -- & $\ldots$ & $\ldots$ & $\ldots$ & $\ldots$ & -. \\
\hline & SM-02 & - & - & -- & $\ldots$ & - & $\ldots$ & - - & -. \\
\hline & W-01 & 5.3 & $\cdots$ & $\cdots$ & 1.5 & $\cdots$ & $\cdots$ & 1.5 & 9.8 \\
\hline \multirow[t]{9}{*}{ RR-07 } & A- 01 & $\ldots$ & $\ldots$ & $\cdots$ & -- & 2.2 & - & $\ldots$ & -. \\
\hline & A- 02 & 5.8 & 2.9 & 2.3 & - & 5.0 & -- & - & $\cdots$ \\
\hline & $A-03$ & - & 4.2 & 2.1 & - & 2.7 & 2.7 & - & $\cdots$ \\
\hline & S-01 & - & 2.3 & -. & - & 1.9 & - & 2.3 & -. \\
\hline & S- 02 & - & 2.4 & 1.8 & - - & 1.8 & 1.5 & 2.1 & 1.8 \\
\hline & s-03 & 1.6 & 1.5 & $\cdots$ & 2.3 & - & -- & 1.5 & -. \\
\hline & SM-01 & - - & - & - & - - & - & - & - & - \\
\hline & SM-02 & - & 1.8 & $\cdots$ & - & $\ldots$ & 1.5 & $\ldots$ & .. \\
\hline & wo-01 & $\ldots$ & - & 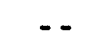 & - - & -- & -. & - & -. \\
\hline
\end{tabular}


Table 4. Ratios of element concentrations in trees--Continued

\begin{tabular}{|c|c|c|c|c|c|c|c|c|c|}
\hline $\begin{array}{l}\text { Sampling } \\
\text { location }\end{array}$ & $\begin{array}{c}\text { Tree } \\
\text { sampled }\end{array}$ & Mn & $\mathrm{Fe}$ & $\mathbf{N} \mathbf{1}$ & $\mathrm{Cu}$ & $\mathrm{Zn}$ & Sr & $\mathrm{Ba}$ & $\mathrm{Pb}^{\# \#}$ \\
\hline AS - 01 & $\begin{array}{r}\text { CW-01 } \\
\text { S-01 } \\
W-01 \\
W-02\end{array}$ & $\begin{array}{r}* \\
-. \\
2.5 \\
-.\end{array}$ & $\begin{array}{l}-- \\
- \\
- \\
-\end{array}$ & $\begin{array}{l}-- \\
-- \\
-- \\
--\end{array}$ & $\begin{array}{l}-- \\
-- \\
-- \\
--\end{array}$ & $\begin{array}{l}-- \\
-- \\
--\end{array}$ & $\begin{array}{l}-- \\
-- \\
--\end{array}$ & $\begin{array}{l}- \\
-- \\
-\end{array}$ & $\begin{array}{r}<1.0 \\
<1.0 \\
1.6 \\
<1.0\end{array}$ \\
\hline CC -02 & $\begin{array}{c}\mathrm{C} 0-01^{\#} \\
\mathrm{~S}-01 \\
\mathrm{~W}-01\end{array}$ & $\begin{array}{l}-- \\
\cdots\end{array}$ & $\begin{array}{l}-- \\
--\end{array}$ & $\begin{array}{l}-- \\
--\end{array}$ & $\begin{array}{l}-- \\
--\end{array}$ & $\begin{array}{r}-- \\
1.7 \\
-.\end{array}$ & $\begin{array}{l}-- \\
--\end{array}$ & $\begin{array}{l}\cdots \\
1.6\end{array}$ & $\begin{array}{r}1.0 \\
<1.0 \\
2.9\end{array}$ \\
\hline $\mathrm{CC}-03$ & $\begin{array}{l}\text { A-01 } \\
\text { S-01 }\end{array}$ & $\begin{array}{r}-- \\
1.9\end{array}$ & $\begin{array}{l}-- \\
--\end{array}$ & -- & -- & $\begin{array}{r}2.3 \\
-.\end{array}$ & $\begin{array}{l}-- \\
--\end{array}$ & - & $\begin{array}{l}<1.0 \\
<1.0\end{array}$ \\
\hline CC- 04 & $\begin{array}{c}\mathrm{CO}-01^{\#} \\
\mathrm{SM}-01 \\
\mathrm{~W}-01\end{array}$ & $\begin{array}{l}-- \\
--\end{array}$ & $\begin{array}{c}-- \\
-- \\
3.4\end{array}$ & $\begin{array}{c}-- \\
-- \\
1.8\end{array}$ & $\begin{array}{l}-- \\
-- \\
--\end{array}$ & $\begin{array}{l}-- \\
--\end{array}$ & $\begin{array}{r}-. \\
1.5 \\
-.\end{array}$ & $\begin{array}{l}-. \\
2.1 \\
1.6\end{array}$ & $\begin{array}{r}1.6 \\
<1.0 \\
<1.0\end{array}$ \\
\hline CC -05 & $\begin{array}{l}\text { A- } 01 \\
\text { S }-01\end{array}$ & -- & 3.8 & 4.1 & $\begin{array}{l}-- \\
--\end{array}$ & 1.7 & $\begin{array}{l}1.6 \\
1.9\end{array}$ & $\begin{array}{r}1.8 \\
.-\end{array}$ & $\begin{array}{r}<1.0 \\
3.9\end{array}$ \\
\hline RR-06 & $\begin{array}{r}S M-01 \\
\text { SM-02 } \\
W-01\end{array}$ & $\begin{array}{l}\cdots \\
\cdots \\
--\end{array}$ & $\begin{array}{r}-. \\
-- \\
10.9\end{array}$ & $\begin{array}{l}-- \\
- \\
3.0\end{array}$ & $\begin{array}{l}-- \\
--\end{array}$ & $\begin{array}{l}-- \\
-- \\
--\end{array}$ & $\begin{array}{l}-- \\
--\end{array}$ & $\begin{array}{l}- \\
\cdots\end{array}$ & $\begin{array}{r}<1.0 \\
<1.0 \\
3.7\end{array}$ \\
\hline RR-07 & $\begin{array}{r}\text { A-01 } \\
\text { A-02 } \\
\text { A-03 } \\
\text { S-01 } \\
\text { S-02 } \\
\text { S-03 } \\
\text { SM-01 } \\
\text { SM-02 } \\
\text { WO-01 }\end{array}$ & $\begin{array}{l}- \\
-- \\
-- \\
-- \\
-- \\
-- \\
-- \\
--\end{array}$ & $\begin{array}{c}-- \\
-- \\
-- \\
-- \\
2.1 \\
-- \\
-- \\
-- \\
-\end{array}$ & $\begin{array}{r}- \\
- \\
1.8 \\
- \\
2.1 \\
-- \\
- \\
-- \\
-\end{array}$ & $\begin{array}{r}2.9 \\
2.8 \\
1.8 \\
-- \\
-. \\
-- \\
- \\
- \\
-\end{array}$ & $\begin{array}{c}-. \\
-- \\
-- \\
- \\
4.2 \\
- \\
- \\
-- \\
-\end{array}$ & $\begin{array}{r}1.6 \\
1.5 \\
3.6 \\
- \\
1.5 \\
1.5 \\
-. \\
1.6 \\
.-\end{array}$ & $\begin{array}{r}1.6 \\
2.2 \\
2.4 \\
-. \\
1.8 \\
1.9 \\
-. \\
4.3 \\
.-\end{array}$ & $\begin{array}{l}<1.0 \\
<1.0 \\
<1.0 \\
<1.0 \\
<1.0 \\
<1.0 \\
<1.0 \\
<1.0 \\
<1.0\end{array}$ \\
\hline
\end{tabular}

"A background tree was unavailable for cottonwood. Concentrations of some elements (*) seem elevated relative to those of other trees at location AS-01.

* Willow oak was used for calculation of element ratios in cherrybark oak.

\#\# Average concentrations, in micrograms/gram, of 1987, 1989, and 1990 growth rings. Ratios were not used because concentrations of lead in some rings of background trees were less than the detection limit. 
Table 5. Ratios of elements (dissolved) in water sampled near the American Creosote Works abandoned plant site compared to those in background water samples

ISamples from Central Creek and the unnamed tributary were collected just upstream from the confluence with the South Fork Forked Deer River. Two background streams were sampled, and the higher concentration of each element was used to construct ratios. See Bradfield and others (1993) for sampling locations and concentration data. --, ratio less than 1.5 ; n.d., no data]

\begin{tabular}{|c|c|c|c|c|c|c|c|c|}
\hline site & Si & $\mathbf{P}$ & $\mathbf{s}$ & C1 & $\mathbf{K}$ & $\mathrm{Ca}$ & Ti & Cr \\
\hline \multicolumn{9}{|l|}{ Central } \\
\hline Creek & -- & n.d. & 11.3 & 3.3 & 3.6 & 14.9 & n.d. & - \\
\hline \multicolumn{9}{|l|}{ Unnamed } \\
\hline Tributary & $\cdots$ & n.d. & 18.4 & 1.5 & 5.7 & 7.6 & n.d. & - \\
\hline Site & Mn & $\mathbf{F e}$ & $\mathbf{N i}$ & $\mathbf{C u}$ & $\mathrm{Zn}$ & Sr & $\mathrm{Ba}$ & $\mathbf{P b}$ \\
\hline \multicolumn{9}{|l|}{ Central } \\
\hline Creek & 4.7 & 24.7 & -- & $\cdots$ & 4.0 & 5.7 & 3.1 & $\cdots$ \\
\hline \multicolumn{9}{|l|}{ Unnamed } \\
\hline Tributary & -- & -- & -- & -- & -- & 3.8 & -- & $\cdots$ \\
\hline
\end{tabular}

\section{Concentrations and Trends in Entire Growth-Ring Series}

A11 sampled trees were established after the ACW facility became operational. Even so, most compounds associated with contamination at the site would be expected to move slowly in ground water, and thus it is possible that their arrival and presence at some sampling locations could be inferred from the tree-ring results. In addition, two important events---the construction of the levee in 1973 and events requiring emergency responses or

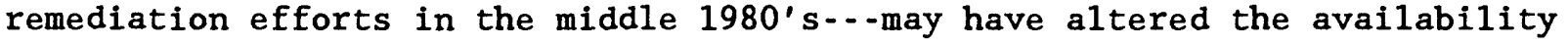
and (or) transport of contaminants. The construction of the levee altered the flow of surface runoff from the main process area of the facility and led to the formation of additional lagoons for storage of waste liquids.

\section{Trees at the Site}

Cores were collected from four small trees that grow within the areas of darkened soil between the lagoons and the former main processing area of the facility (location AS-01; fig. 2). Each ring of each tree was irradiated. Analyses performed for the RI/FS (S\&ME, Inc., 1988) indicated considerable spatial heterogeneity in the concentrations of organic compounds and iron in onsite soils and ground water; areas of darkened soil generally were consistent with the highest contaminant concentrations in ground water. 
Two willows about $100 \mathrm{~m}$ apart were sampled near the main processing area. Rings of the tree farther to the north ( $W-01$ ) contained greater concentrations of manganese, calcium, strontium, zinc, and lead than those of the more southern tree (W-02). The concentrations of lead in tree W-01 ranged from 1.6 to $7.3 \mathrm{ug} / \mathrm{g}$, but lead was detected in only two of four rings of tree W-02 (maximum concentration, $0.5 \mathrm{ug} / \mathrm{g}$ ). The concentration of iron abruptly increased relative to adjacent rings in the 1988 rings of both willows.

A sycamore (S-01) growing near tree W-01 contained elevated concentrations of potassium and chloride relative to sycamores at background locations. Concentrations of lead in rings of tree S-01 were less than in those of tree W-01 but greater than in rings of tree W-02. A1though a background cottonwood was not sampled, a cottonwood (CW-01) near tree W-02 contained seemingly elevated concentrations of sulfur and manganese and, like tree W-02, contained low concentrations of lead $(0.2-0.6 \mathrm{ug} / \mathrm{g})$.

Trees near the former main processing area generally did not contain elevated concentrations of potassium, phosphorus, calcium, iron, nickel, and chromium, as did some trees sampled at locations CC-04, CC-05, RR-06, and RR-07 (table 4). These differences in part may be due to the young age and small roots of onsite trees. However, trees at the other locations are downgradient from the levee and lagoons, where contaminant alterations along ground- and surface-water flowpaths may increase the availability of some elements for uptake by trees.

\section{Trees along Central Creek}

Multielement analysis was performed on a cherrybark oak growing at location CC-02 and on another growing at location CC-04. The oak at location CC-02 grows in an area between Central Creek and part of the levee constructed in 1973 that prevents the area from receiving overland-flow drainage from the most contaminated parts of the site. The tree does not seem to grow within the zone of contaminated soils or within the estimated extent of the NAPL ground-water contamination ( $\$ \& M E$, Inc., 1988). Although unconfirmed, it is likely that the aqueous-phase plume has reached this location because of the proximity of the lagoons. The other sampled cherrybark oak grows at location CC-04 near the southwestern corner of the site, downgradient from the levee and lagoons. Contamination in ground-water was detected in this area (Parks and others, 1993).

A comparison of selected element concentrations in the rings of both oaks is shown in figure 4. Concentrations of most elements generally are comparable within the outermost three irradiations $(1987,1989,1990)$ of both trees. However, the concentrations of numerous elements in the oak at location CC-04 were greater in rings that formed during 1966-86 than in the three outermost sapwood rings, particularly concentrations of calcium, manganese, iron, copper, nickel, zinc, strontium, and lead. Furthermore, concentrations of trace metals increased abruptly in the 1976 ring and remained elevated in the 1978 ring. Although the 1976 ring was not irradiated in the oak at location CC-02, increased concentrations of trace metals were not detected in the 1978 ring. Differences between the concentrations of some elements in the two oaks may be due to differences in element availability at the two sampling locations. 

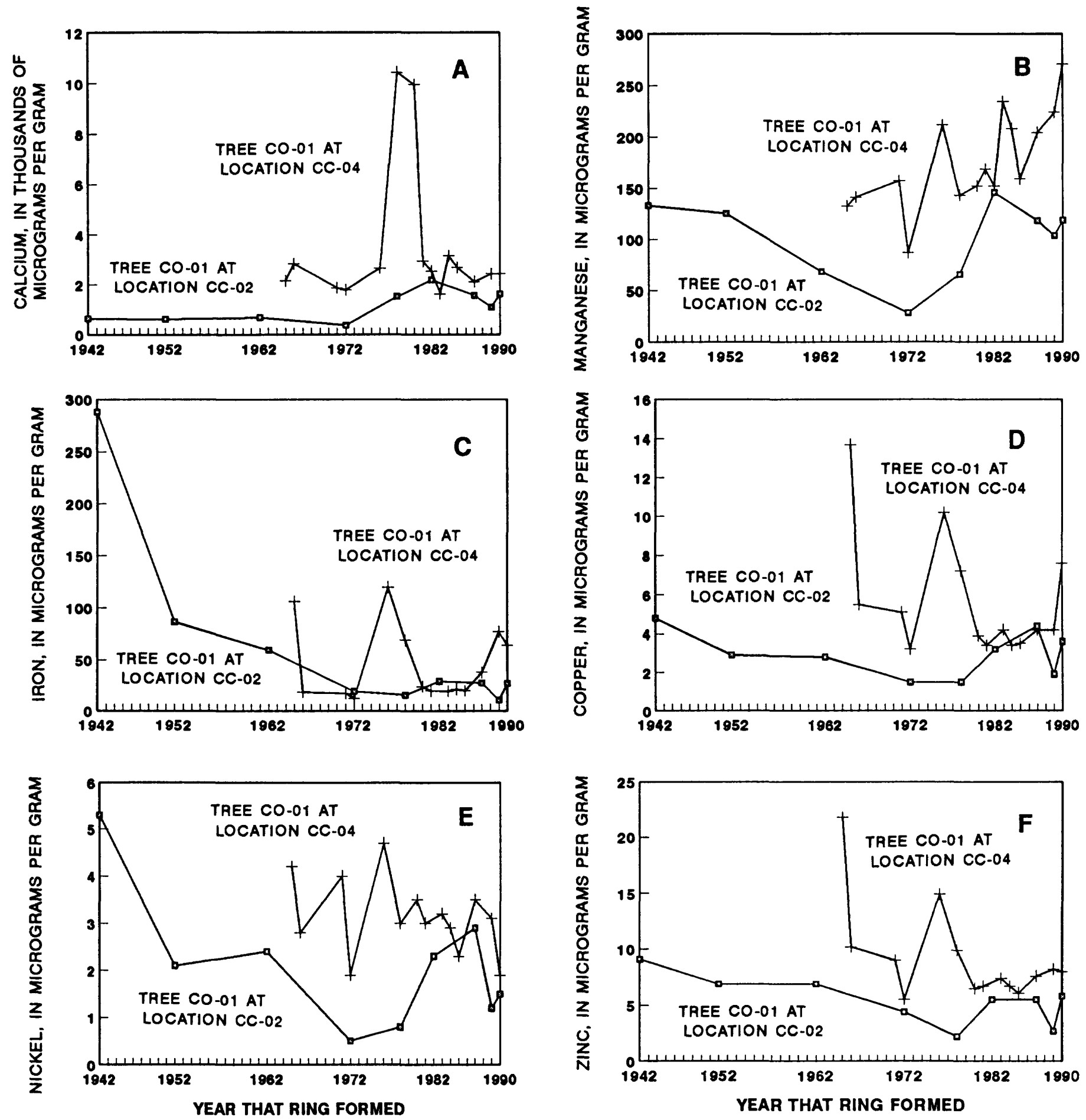

Figure 4. Concentrations of selected elements in rings of cherrybark oaks at sampling locations CC-02 and CC-04 just east of Central Creek. (A) calcium; (B) manganese; (C) iron; (D) copper; (E) nickel; (F) zinc. 
Ring-calcium concentrations and concentration trends differed between the two cherrybark oaks (fig. 4A). The oak at location CC-02 contained lower concentrations of calcium in heartwood $(370-681 \mathrm{ug} / \mathrm{g}$ ) than in sapwood $(1,090-2,170 \mathrm{ug} / \mathrm{g})$; the sapwood ring (1978) nearest the heartwood contained more than four times the calcium concentration of the outermost heartwood irradiation (1972). Thus, it seems highly likely that the overall concentration trend of calcium in this tree resulted from the translocation of calcium from older to younger rings during the conversion of inner sapwood to outer heartwood (fig. 3, fig. 4A). Additional supporting evidence is that the concentration trend of calcium was similar to that of potassium $(R=0.88$, but not significant at $\mathrm{p}=0.05)$, an element strongly translocated in most oaks studied to date by the USGS.

In heartwood rings (1965-1972) of the oak from location CC-04, however, calcium concentrations ranged from 1,770 to $2,810 \mathrm{ug} / \mathrm{g}$ but did not differ from the range of concentrations in seven sapwood rings that formed between 1981 and 1990, or from the sapwood ring (1976) closest to the heartwood (fig. 4A). Additionally, the correlation was low ( $\mathrm{R}=0.37$, not significant) between the concentrations of calcium and potassium. Thus, the ranges and relative concentrations of calcium along the core radii differed between the two oaks. This cannot be explained by differences in the yearly range of irradiated rings between the trees, but possibly may be due to greater calcium availability at location CC-04 than at location CC-02. The 1978 and 1980 sapwood rings of the oak at location CC-04 contained calcium concentrations of 10,440 and $9,970 \mathrm{ug} / \mathrm{g}$ (fig. 4A), respectively, the highest concentrations of ring calcium that have been detected in all USGS element-analysis studies to date. Microscopic examination of these two rings did not reveal alterations by fungi or other wood pathogens that might have caused the increased calcium concentrations.

Although it could be argued that calcium availability for uptake by trees has always been greater at location CC-04 than at location CC-02, the anomalous translocation pattern and extremely high concentrations in two sapwood rings suggest the possibility that calcium availability increased at some time during the life of the oak at location CC-04. This tree may have responded to increased calcium availability by translocating amounts in excess of physiological requirements into previously formed rings, some of which are presently in the heartwood and some of which are sapwood rings near the heartwood/sapwood boundary. Calcium translocated into the earliest irradiated heartwood ring (1965) could have occurred only when the ring was part of the sapwood. Based on an inspection of the relative proportions of heartwood to sapwood among oaks collected for this study, conversion of the 1965 ring to heartwood probably occurred in the early to middle $1980^{\prime} s$, a time during which site remediation was attempted. However, owing to a poor understanding of the dynamics of element translocation, it is also possible that excess concentrations of calcium were translocated only minimally from outer to inner rings, and that the 1978 and 1980 rings reflect actual increases in calcium availability in those years. Vroblesky and others (1992) detected potassium translocation from outer to inner rings in tulip trees growing over a potassium-contaminated aquifer, but they did not study oaks.

Irradiations were performed on the 1942, 1952, 1962, and 1972 rings of the oak at location CC-02. All were heartwood rings that formed before the construction of the levee; the 1942 ring contained the greatest concentrations 
of silicon, chromium, iron, nickel, copper, and zinc. Concentrations of iron in the 1942, 1952, and 1962 rings exceeded that of the fourth highest concentration detected $(29.1 \mathrm{ug} / \mathrm{g}$ in the $1982 \mathrm{ring}$ ) by factors of about 10,3 , and 2, respectively (fig. 4C). Iron and nickel apparently were not readily subject to translocation in trees sampled during previous studies (Vroblesky and Yanosky, 1990; Yanosky and Vroblesky, 1992). There was a significant positive correlation between concentrations of chromium and silicon, and a moderately high correlation between iron and nickel ( $R=0.88$, not significant at $\mathrm{p}=0.05)$. It seems unlikely that the elevated concentrations of some trace metals in pre-1973 rings resulted from their translocation from outer to inner rings. Rather, it seems more reasonable that the oak at location CC-02 grows where element concentrations and availability differed before and after the construction of the levee in 1973. Prior to construction of the levee, wastewater from the facility was routinely discharged into Central Creek (S\&ME, 1988) and overland runoff from the site was not prevented from reaching the sampling location.

A willow sampled at location CC-02 grows on the levee face sloping toward Central Creek and germinated about 10 years after the levee was built. A willow sampled at location CC-04 germinated about 1970 and grows closer to Central Creek and at a slightly higher elevation than the cherrybark oak, and, thus is apparently on the periphery of the drainage flowpath from the main part of the facility. The range of concentrations of iron, nickel, and chromium is greater in rings of the willow from location CC-04 than in those of the willow from location CC-02; however, the concentrations of calcium did not differ between the two willows, or among the two willows and the background willow. Concentrations of iron, nickel, and chromium did not increase in the willow, as they did in the 1976 ring of the oak sampled from location CC-04. However, concentrations of these metals in the 1978 ring of the willow generally exceeded those in the 1976 and 1980 rings.

A silver maple (SM-01) was sampled at location CC-04 about $50 \mathrm{~m}$ downgradient from tree C0-01. Concentrations of trace elements in tree SM-01 generally were less than those detected in trees $C 0-01$ and $W-01$, but the average concentration of calcium $(1,313 \mathrm{ug} / \mathrm{g})$ in six irradiated rings that formed during the $1980^{\prime} s$ exceeded that of the same number of irradiated rings in two background maples ( 805 and $921 \mathrm{ug} / \mathrm{g}$ respectively), and in trees SM-01 and SM-02 at location RR-06 ( 869 and $842 \mathrm{ug} / \mathrm{g}$, respectively). Calcium concentrations in both background silver maples were markedly less in heartwood than in sapwood rings near the heartwood/sapwood boundary, and further declined from inner to outer sapwood rings. Although only one heartwood ring was irradiated in tree SM-01, sapwood concentrations of calcium near the heartwood/sapwood boundary were comparable to those of background trees; however, calcium concentrations did not decline from inner to outer heartwood rings, which might be expected if calcium availability increased during the interval of sapwood growth. Thus, with regard to the amount and radial distribution of calcium along the core, tree SM-01 seems more similar to tree C0-01 than to the silver maples at location RR-06 and at the background sampling locations.

An ash and a sycamore were sampled at locations CC-03 and CC-05. Both sites are just west of Central Creek (fig. 2), and the ash and sycamore sampled at each site were comparable in size and age. The sycamore at location CC-05 contained greater concentrations of iron, nickel, and chromium 
than did the sycamore at location CC-03 (fig. 5); furthermore, concentrations began to increase steadily throughout the middle 1970's and were particularly elevated in the outermost three rings analyzed. Concentrations of iron, nicke1, and chromium in the 1987 ring were $1,190,7.9$, and $16.0 \mathrm{ug} / \mathrm{g}$, respectively--among the greatest detected in this study. The concentrations and concentration trends of these elements differ from those in the sycamore at location $\mathrm{CC}-03$ and in both trees from background locations. Concentrations of calcium increased in the outermost sapwood rings of the sycamore at location CC-05, unlike in the sycamore at location CC-03. The enrichment of calcium in the outer sapwood relative to background trees also was detected in the silver maple sampled at location $\mathrm{CC}-04$ and in an ash, a sycamore, and a silver maple sampled at location RR-07.

The ash trees sampled at locations CC-03 and CC-05 contained comparable concentration ranges of most elements, although the range of barium in the former tree (up to $59.8 \mathrm{ug} / \mathrm{g}$ ) is less than that in the latter tree (up to $113.1 \mathrm{ug} / \mathrm{g}$ ). Concentrations of phosphorus and potassium were generally greater in both ash trees than in the background ash tree; however, greater concentrations of chromium and iron were detected in the background tree. Compared to the respective sycamore at each site, ash trees selectively accumulated barium but not manganese and chromium.

\section{Trees along the Railroad Track}

Element analysis was performed on each ring of a willow (W-01) that became established at location RR-06 (fig. 2) in 1976. Concentrations of iron and chromium increased abruptly in the 1986 ring and remained elevated thereafter relative to rings formed in 1985 and before (fig. 6). The concentrations of iron in the 1988 and 1989 rings $(2,090$ and $1,610 \mathrm{ug} / \mathrm{g}$, respectively) were the greatest detected in this or any previous USGS study. Concentrations of chromium in these two rings were 32.7 and $21.6 \mathrm{ug} / \mathrm{g}$, respectively, the former concentration being greater than that of any ring in any previous USGS study. Concentrations of silicon, chloride, and nickel also were elevated in rings that formed from 1986 through 1990. The willow also contained elevated concentrations of chloride in the 1979, 1980, and 1981 rings (fig. 6).

A silver maple (SM-01) approximately the same age as the willow grows along the north side of the railroad tracks and about $10 \mathrm{~m}$ closer to the South Fork Forked Deer River. Fewer rings of the silver maple were analyzed than of the willow. The concentrations of silicon, chloride, iron, chromium, and nickel increased abruptly in the 1987 ring; the 1986 ring was not irradiated. Although concentrations of these elements in the silver maple were less than those in the willow, possibly owing to physiological differences between the species, the timing and magnitude of increased concentrations were approximately comparable. As in the willow, ring-chloride concentrations in the silver maple were moderately elevated during the late 1970's and early 1980 's.

Synchronous elevations of the same elements in the outer rings of trees W-01 and SM-01 suggest that rings of both trees developed during periods of similar element availability, as might be expected if roots were irrigated with contaminated water resulting from past activities at the site. Both 

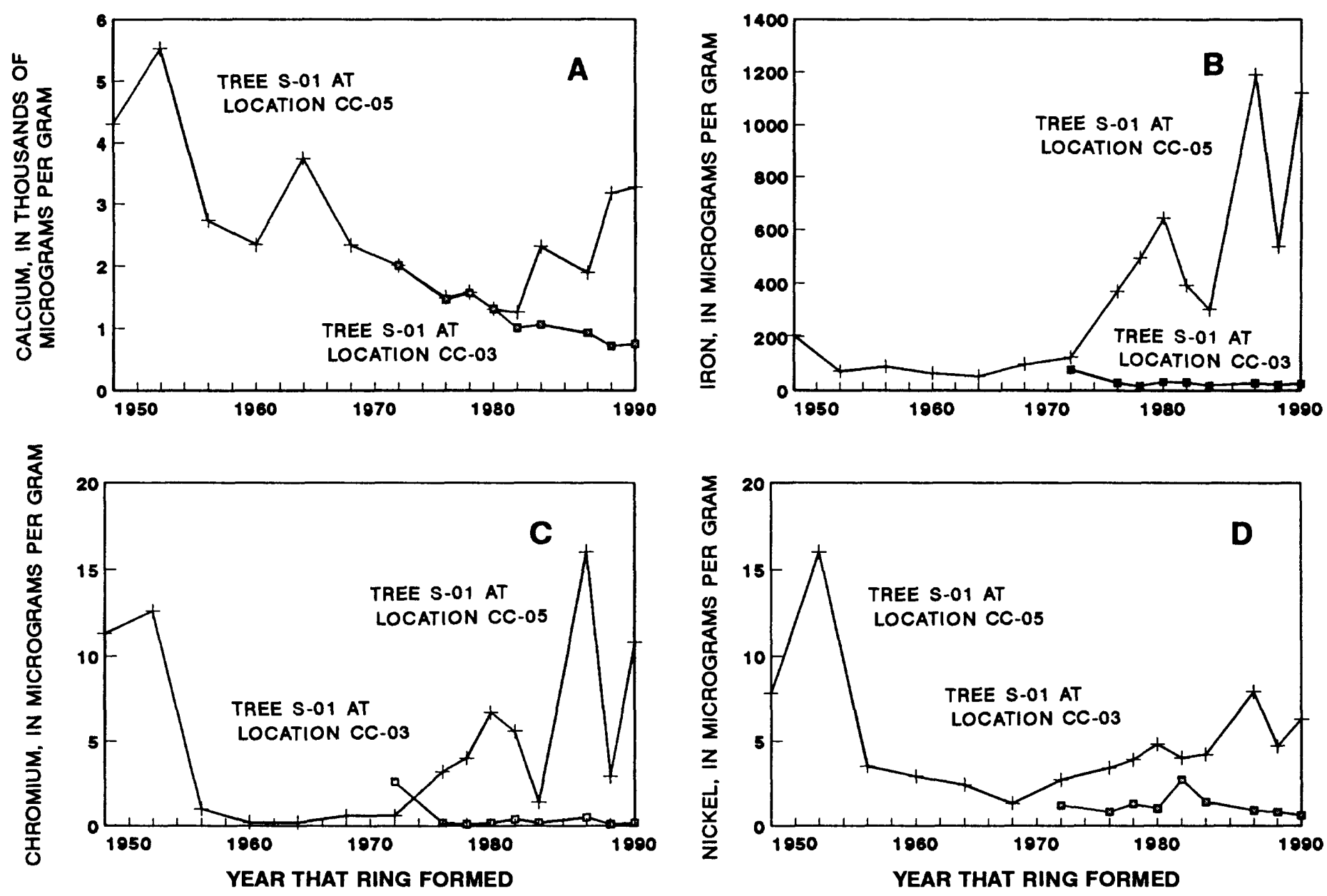

Figure 5. Concentrations of selected elements in rings of sycamores at sampling locations CC-03 and CC-05 just west of Central Creek. (A) calcium; (B) iron; (C) chromium; (D) nickel.

trees are approximately $40 \mathrm{~m}$ from the large lagoon at the southwestern corner of the site. Based on flow direction and an estimated velocity for local alluvial materials at about $13.4 \mathrm{~m} / \mathrm{yr}$ ( $S \& M E$, Inc., 1988), ground water moving away from the lagoon would be expected to reach these trees within about 3 years. Movement of a contaminant plume would likely be somewhat different, depending on the type of contaminants and the physiochemical interactions along the flow path. The maximum concentration of metals is in the 1988 ring of tree W-O1 and decreases thereafter, possibly indicating the period of maximum environmental availability of the elements at sampling location RR-06. However, the tree grows adjacent to the unnamed tributary draining an industrial area east of the site that may serve as the contaminant source; ground water sampled from an alluvial well in the industrial area contained large concentrations of chromium, iron, and nickel.

A second silver maple (SM-02) at location RR-06 is $150 \mathrm{~m}$ to the west of tree SM-01 and about $75 \mathrm{~m}$ from the South Fork Forked Deer River. The tree grows just north of the railroad tracks on an elevated slope above the ditch carrying lagoon overflow to the river. Tree SM-02 did not contain 

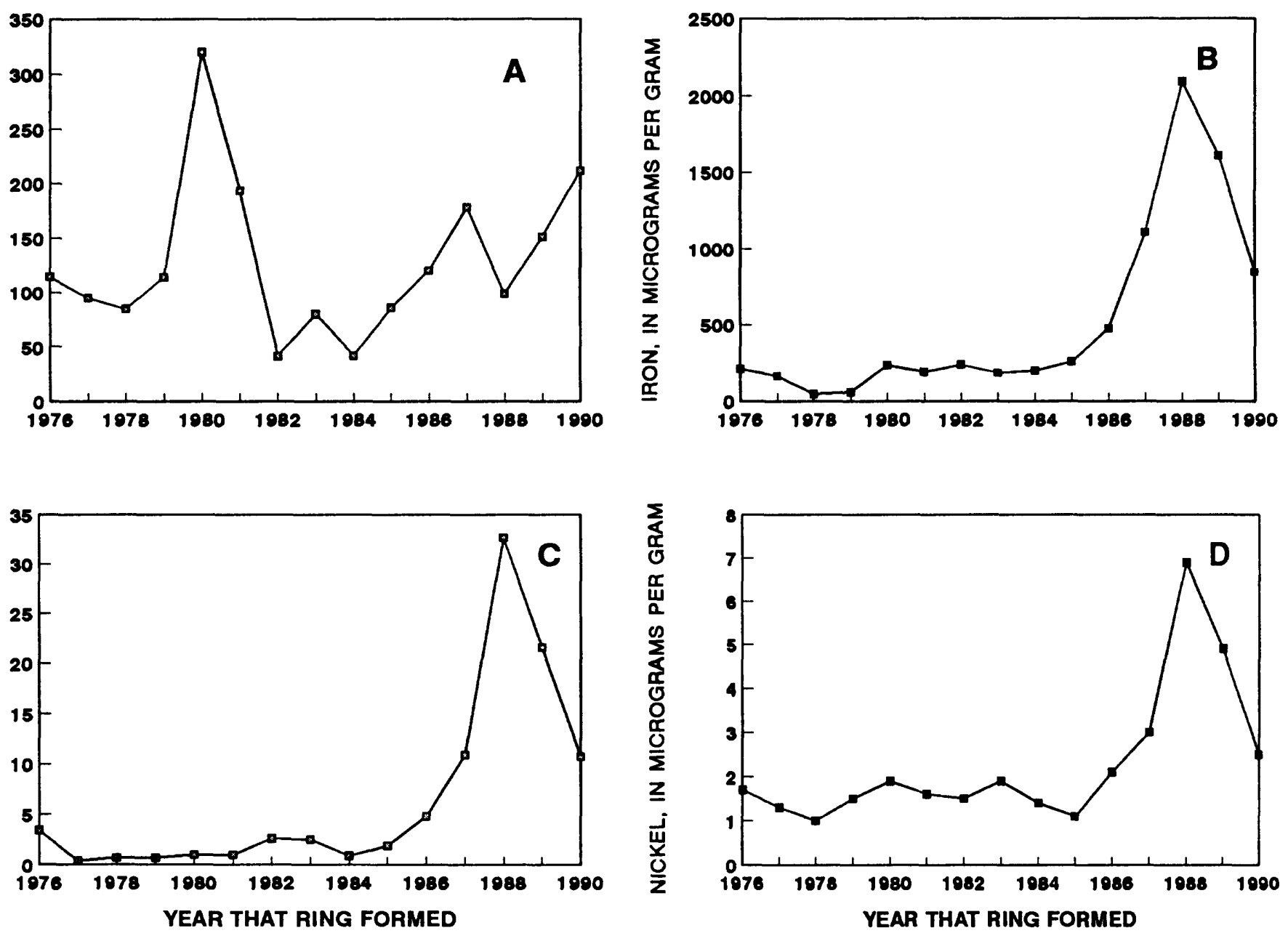

Figure 6. Concentrations of selected elements in rings of a willow growing just north of the railroad tracks at sampling location RR-06. (A) chloride; (B) iron; (C) chromium; (D) nickel.

concentrations of chromium, iron, and nickel comparable to those detected in trees W-01 and SM-01, suggesting that it grows in a region of element availability differing from that of the other two trees at location RR-06. Similarly, the tree also contained smaller concentrations of most elements, particularly of calcium, chloride, phosphorus, and barium, than did the silver maple (SM-01) sampled at location CC-04, from which it is separated by about $40 \mathrm{~m}$ across the open area. Thus, despite its proximity to location CC-04, the sloped region immediately north of the railroad tracks may be above the periphery of the flowpath, and the construction of the drainage ditch may further divert contaminated flow away from the tree.

of nine trees sampled south of the railroad tracks, five trees (A-01, S-01, S-02, SM-01, and WO-01) grow within about $50 \mathrm{~m}$ from the tracks and four trees (A-02, A-03, S-03, and SM-02) grow within about $100 \mathrm{~m}$ farther to the south. Trees A-03 and S-02 have extremely narrow rings beginning in the middle 1970's and late-1980's, respectively, and thus even the narrowest irradiation beam encompassed three to five rings simultaneously. 
Among ash trees at sampling location RR-07, tree A-02 contained the greatest relative concentrations of silicon, sulfur, and zinc. The concentrations of silicon in the 1987 and $1990 \mathrm{rings}$ were 1,152 and $605 \mathrm{ug} / \mathrm{g}$, respectively, the former concentration being the highest detected in this study. Ring-concentrations of copper in trees A-01 (up to $122 \mathrm{ug} / \mathrm{g}$ ) and A-02 (up to $114 \mathrm{ug} / \mathrm{g}$ ) greatly exceeded those of tree A-03 (up to $17 \mathrm{ug} / \mathrm{g}$ ). Extremely large concentrations of potassium were detected in the 1964 and 1968 rings $(6,945$ and $6,302 \mathrm{ug} / \mathrm{g}$, respectively) and in the $1987 \mathrm{ring}(9,641 \mathrm{ug} / \mathrm{g})$ of tree A-02 ( $f i g .7 a)$; in the other ashes at location RR-07, no ring contained a concentration of potassium that exceeded $3,000 \mathrm{ug} / \mathrm{g}$.

Among sycamores at sampling location RR-07, trees S-01 and S-02 contained the largest concentration of phosphorus detected in this study (up to 2,450 and $1,470 \mathrm{ug} / \mathrm{g}$, respectively). In nearly all trees studied to date by the USGS, concentrations of phosphorus increased from inner to outer rings, and were particularly small within heartwood rings. Ring-potassium concentrations in trees S-01 and S-02 also were higher than those in tree S-03 (up to 1,087 $\mathrm{ug} / \mathrm{g})$. Concentrations of chromium, iron, and nicke1 in rings of tree S-02 were greater than in rings of trees S-01 and S-03, particularly in the 1976 ring and in rings formed in 1980 and thereafter. The concentration of chromium in the $1976 \mathrm{ring}(26.4 \mathrm{ug} / \mathrm{g})$ of tree $\mathrm{S}-02$ was the second greatest detected in this study.

The silver maple farther from the railroad tracks (SM-02) contained extremely large concentrations of potassium in heartwood rings relative to other silver maples in this study; concentrations ranged from 4,000 to 9,443 $\mathrm{ug} / \mathrm{g}$ (fig. 7b). Only two heartwood rings (1964 and 1968) were irradiated in tree SM-01, and concentrations of potassium were 671 and $440 \mathrm{ug} / \mathrm{g}$, respectively (fig. $7 \mathrm{~b}$ ). In both background silver maples, concentrations of potassium were smaller in heartwood rings than in sapwood rings near the heartwood/sapwood boundary, suggesting that potassium is actively translocated from inner to outer rings. The nine sapwood rings analyzed in tree SM-01 contained potassium concentrations ranging only from 1,016 to $1,847 \mathrm{ug} / \mathrm{g}$ (fig. 7b), but potassium concentrations in the seven sapwood rings of tree SM-02 ranged from 1,855 to $4,233 \mathrm{ug} / \mathrm{g}$ (fig. $7 \mathrm{~b}$ ). The greatest concentration of potassium detected in any silver maple sampled outside location RR-07 was $3,058 \mathrm{ug} / \mathrm{g}$ (tree SM-01 at location BL-09), although most were less than 2,000 ug/g. Additionally, sapwood rings that formed after 1980 in tree SM-02 contained higher concentrations of phosphorus than those in tree SM-01. Ring concentrations of barium along the entire core radius also were greater in tree SM-02, ranging from 32.5 to $116.7 \mathrm{ug} / \mathrm{g}$, compared to a range of only 6.4 to $32.0 \mathrm{ug} / \mathrm{g}$ in tree SM-01.

Microscopic examination of the heartwood rings irradiated in tree SM-02 detected a mottled appearance of rings formed in 1968 and 1972; the three rings closest to the pith appeared unaffected, but this could not be confirmed. If mottling resulted from degradation by wood pathogens, potassium concentrations in the five heartwood rings may have resulted from infection rather than from environmental availability. Although the concentrations of potassium were greatest in the two innermost heartwood rings, this could have resulted from translocation if both rings were part of the sapwood when pathogens seemingly first attacked the tree in the middle 1970 's. Sapwood rings of tree SM-02 do not appear to have been subjected to wood pathogens on the basis of microscopic examination. 

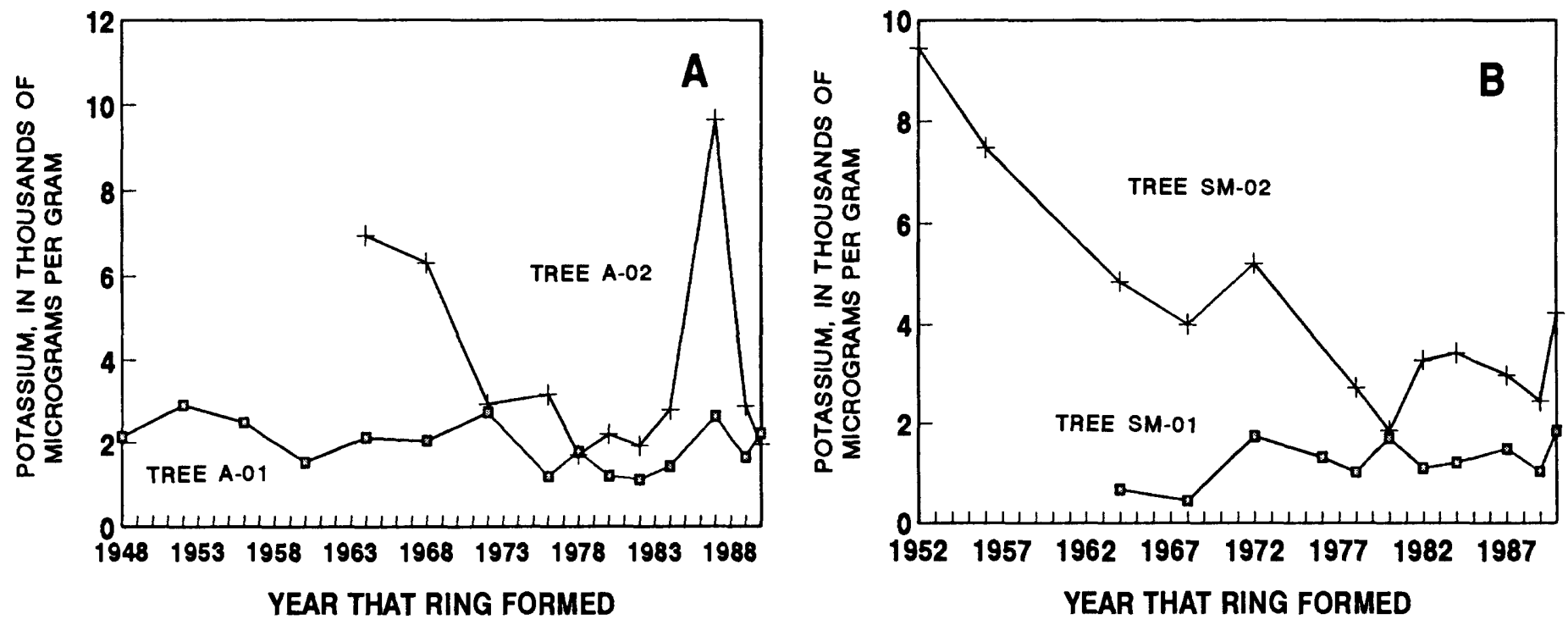

Figure 7. Concentrations of potassium in selected trees sampled south of the railroad tracks at location RR-07. (A) ash (trees A-01 and A-02); (B) silver maple (trees SM-01 and SM-02).

It also is possible that the large concentrations of potassium in the heartwood of tree SM-02 are not due to infection but rather to environmental availability. If the tree indeed grows where potassium availability is great, as is suggested by large concentrations of potassium in some adjacent trees, the large concentrations of potassium in heartwood probably resulted at least in part from translocation from outer to inner rings. Because the heartwood/sapwood boundary is a barrier through which active translocation through rays cannot occur, translocation of potassium into the 1952 ring (the oldest ring irradiated) must have occurred while the 1952 ring was within the sapwood. The 1952 ring probably was converted from sapwood to heartwood in the middle 1970's, based on an inspection of the number of sapwood rings in the various silver maples sampled in the study area. Increased availability of potassium in the middle 1970's would account for the high concentrations of potassium detected in all heartwood rings. Thus, the middle to late 1970's seems a reasonable earliest estimate of the onset of increased potassium availability. This hypothesis is consistent with the high concentrations of potassium detected in the 1964 and 1968 rings of tree A-02, which still remain within the sapwood (fig. 7a).

Although only one willow oak was sampled at location RR-07, multielement concentrations were comparable to those of willow oaks at both background sampling locations.

When all trees at location RR-07 were considered collectively, the concentration ranges of potassium were lowest in trees A-01, SM-01, and W0-01. These are the trees closest to the railroad tracks. Concentrations of phosphorus also were low in these trees. With increasing distance from the railroad tracks, however, greater concentrations of potassium and phosphorus were detected in trees S-01, S-02, A-02, and SM-02. Phosphorus concentrations were greatest in trees S-01 and S-02, which grow at about the same distance from the railroad tracks but about $50 \mathrm{~m}$ apart; potassium concentrations were 
greatest in trees A-02 and SM-02, which grow about $125 \mathrm{~m}$ from the railroad tracks and about $25 \mathrm{~m}$ apart. Similarly, the greatest concentrations of some trace metals at location RR-07 were detected in trees A-02 and S-02. Trees S-03 and A-03 grow about 15 and $25 \mathrm{~m}$, respectively, from tree A-02 and contained minimally elevated concentrations of phosphorus; concentrations of potassium in trees $\mathrm{S}-03$ and $\mathrm{A}-03$ were comparable to those contained in trees nearest the tracks. When trees at location RR-07 were compared to all other trees in this study, the concentrations of potassium and phosphorus in some sycamore, ash, and silver maple trees at this location were greater than those contained in trees from background locations, from the former main processing part of the site, and from locations along Central Creek.

\section{Correlations of Element Concentrations in Tree Rings}

Trees of the same species, size, and age would be expected to contain similar ring-element concentrations if they grow in similar environments. An environmental change that alters the availability of an element at one site, but not at others, might result in changes in the concentrations of that element in rings formed thereafter, or even in previously formed rings if the element is translocated from outer to inner sapwood. Over time, this would result in differences in concentration trends among trees.

However, it is unknown to what degree the increased availability of one element also affects the concentrations of other elements taken up by trees. Large-scale biogeochemical alterations, such as those possibly occurring within the study area, may result in the increased availability of entire suites of elements rather than of one element; likewise, little is known concerning the expected interactions among these elements. An environmental alteration might increase the correlations between elements that were uncorrelated previously, or might decrease what was formerly a strong correlation. Accordingly, in addition to analyses of ring-element concentrations, element correlations were compared among trees at the various sampling locations.

Significant correlations among elements within individual trees are listed in table 6 . In most sampled trees, barium, calcium, and strontium were intercorrelated in various combinations, as would be expected considering their similar chemical properties. Calcium was correlated with potassium, manganese, and $z$ inc in some trees (table 6). Various combinations of correlations were detected among iron, chromium, copper, nickel, and manganese, particularly when trees contained elevated and sustained concentrations of these metals.

Element correlations among members of each species and among trees at each location strengthen the hypothesis that element availability differs among sampling locations. For example, the ash at location CC-03 contained element concentrations that seem comparable to those of the ash at location CC-05. However, correlations among elements differed greatly between the two trees, particularly those among nutrients and trace metals (table 6). Tree A-01 at location RR-07 had element correlations identical to those of the ash at location CC-03, but these element correlations differ from those of trees A-02 and A-03 also at location RR-07. Tree A-02 was more similar to the ash 
Table 6. Elements correlated (in brackets) within individual trees in which seven or more irradiations were performed

Correlations determined by Pearson Correlation Matrix; Bonferroni $p$ values $<0.05$;

-- no significant correlations; see table 2 for an explanation of abbreviations of

sampling locations and table 3 for tree nomenclature.]

\begin{tabular}{|c|c|c|c|}
\hline $\begin{array}{l}\text { Sampling } \\
\text { location }\end{array}$ & $\begin{array}{l}\text { Tree } \\
\text { sampled }\end{array}$ & $\begin{array}{c}\text { Number of } \\
\text { irradiations }\end{array}$ & Elements correlated \\
\hline CC -02 & $\mathrm{CO}-01$ & 9 & {$[\mathrm{Cr}, \mathrm{Si}]$} \\
\hline $\mathrm{CC}-03$ & $\begin{array}{l}\text { A-01 } \\
\text { S-01 }\end{array}$ & $\begin{array}{l}9 \\
9\end{array}$ & $\begin{array}{l}{[\mathrm{Ba}, \mathrm{Ca}],[\mathrm{Ca}, \mathrm{Sr}]} \\
{[\mathrm{Ba}, \mathrm{Ca}],[\mathrm{Ba}, \mathrm{Sr}],[\mathrm{Ca}, \mathrm{S}]}\end{array}$ \\
\hline CC- 04 & $\begin{array}{r}\mathrm{CO}-01 \\
\mathrm{SM}-01 \\
\mathrm{~W}-01\end{array}$ & $\begin{array}{r}14 \\
13 \\
7\end{array}$ & 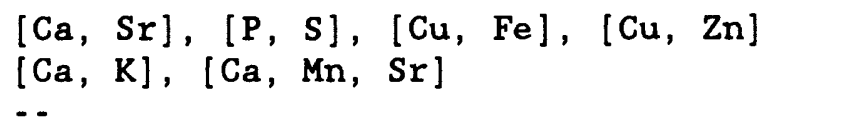 \\
\hline CC -05 & $\begin{array}{l}A-01 \\
S-01\end{array}$ & 15 & $\begin{array}{l}{[\mathrm{Ba}, \mathrm{S}],[\mathrm{Ba}, \mathrm{Sr}],[\mathrm{Cl}, \mathrm{S}],[\mathrm{Cu}, \mathrm{S}],} \\
\quad[\mathrm{Cu}, \mathrm{Sr}],[\mathrm{K}, \mathrm{S}],[\mathrm{P}, \mathrm{Mn}],[\mathrm{Si}, \mathrm{Zn}] \\
{[\mathrm{Ba}, \mathrm{Ca}, \mathrm{Sr}],[\mathrm{Cr}, \mathrm{Ni}, \mathrm{Mn}],[\mathrm{Cu}, \mathrm{Mn}, \mathrm{Sr}]}\end{array}$ \\
\hline RR-06 & $\begin{array}{r}\text { SM-01 } \\
\text { SM-02 } \\
\text { W-01 }\end{array}$ & $\begin{array}{r}7 \\
13 \\
15\end{array}$ & $\begin{array}{l}{[\mathrm{Fe}, \mathrm{Ni}]} \\
{[\mathrm{Ba}, \mathrm{Mn}],[\mathrm{K}, \mathrm{P}]} \\
{[\mathrm{Ca}, \mathrm{K}, \mathrm{Sr}],[\mathrm{Cr}, \mathrm{Fe}, \mathrm{Ni}]}\end{array}$ \\
\hline RR -07 & $\begin{array}{r}\text { A-01 } \\
\text { A-02 } \\
\text { A-03 } \\
\text { S-02 } \\
\text { S }-03 \\
\text { SM }-01 \\
\text { SM-02 }\end{array}$ & $\begin{array}{r}15 \\
11 \\
10 \\
7 \\
10 \\
11 \\
12\end{array}$ & $\begin{array}{l}{[\mathrm{Ba}, \mathrm{Ca}],[\mathrm{Ca}, \mathrm{Sr}]} \\
{[\mathrm{Ba}, \mathrm{Ca}, \mathrm{Sr}],[\mathrm{Ba}, \mathrm{Sr}, \mathrm{Zn}],[\mathrm{Fe}, \mathrm{Mn}]} \\
\quad[\mathrm{Fe}, \mathrm{Ti}],[\mathrm{K}, \mathrm{S}],[\mathrm{P}, \mathrm{Si}] \\
{[\mathrm{Ca}, \mathrm{P}, \mathrm{Ni}],[\mathrm{Si}, \mathrm{Zn}]} \\
{[\mathrm{Ca}, \mathrm{Sr}],[\mathrm{Cr}, \mathrm{Fe}]} \\
{[\mathrm{Ba}, \mathrm{Ca}, \mathrm{Mn}, \mathrm{Zn}],[\mathrm{Cl}, \mathrm{Fe}]} \\
{[\mathrm{Ba}, \mathrm{Ca}],[\mathrm{Ca}, \mathrm{Mn}],[\mathrm{Ca}, \mathrm{Sr}],[\mathrm{K}, \mathrm{P}]} \\
{[\mathrm{Ba}, \mathrm{Ca}, \mathrm{Mn}, \mathrm{Sr}],[\mathrm{P}, \mathrm{S}]}\end{array}$ \\
\hline BL-08 & $\begin{array}{r}\text { A-01 } \\
\text { S-01 } \\
\text { SM-01 } \\
\text { WO-01 }\end{array}$ & $\begin{array}{l}15 \\
15 \\
10 \\
12\end{array}$ & $\begin{array}{l}{[\mathrm{Ba}, \mathrm{Ca}, \mathrm{Sr}],[\mathrm{Cl}, \mathrm{Fe}],[\mathrm{Cu}, \mathrm{S}]} \\
{[\mathrm{Ba}, \mathrm{Sr}],[\mathrm{Cu}, \mathrm{Mn}],[\mathrm{K}, \mathrm{S}, \mathrm{Si}]} \\
{[\mathrm{Ba}, \mathrm{Ca}],[\mathrm{Cr}, \mathrm{Cu}, \mathrm{Ni}],[\mathrm{Cr}, \mathrm{Fe}, \mathrm{Ni}]} \\
{[\mathrm{Ca}, \mathrm{Sr}],[\mathrm{Cr}, \mathrm{Fe}],[\mathrm{Fe}, \mathrm{S}]}\end{array}$ \\
\hline BL-09 & $\begin{array}{l}\text { SM-01 } \\
\text { WO-01 }\end{array}$ & $\begin{array}{r}11 \\
7\end{array}$ & $\begin{array}{l}{[\mathrm{Ba}, \mathrm{Ca}],[\mathrm{Ca}, \mathrm{Sr}, \mathrm{Zn}],[\mathrm{P}, \mathrm{S}]} \\
{[\mathrm{Cu}, \mathrm{Fe}, \mathrm{Zn}],[\mathrm{Cu}, \mathrm{S}, \mathrm{Zn}],[\mathrm{Mn}, \mathrm{Ti}]}\end{array}$ \\
\hline
\end{tabular}

at locations CC-05 than to other ashes; both had correlations among some nutrients and tracae metals, and between potassium and sulfur. Silicon and zinc were correlated in tree A-03 at location RR-07 and in the ash at location CC-05 (table 6).

The sampling-location differences inferred from element correlations among ash trees also were suggested when element correlations were compared among sycamores. The sycamore at location CC-05 had numerous trace-metal 
correlations not detected in the sycamore at location CC-03 (table 6). Tree S-02 at location RR-07 had only two sets of correlations, one being between chromium and iron (table 6); tree S-02 contained greater concentrations of most metals and markedly greater concentrations of potassium than were detected in tree S-03 also at location RR-07. Element correlations in trees S-02 and S-03 seem more similar to those of the sycamore at location CC-05 than to those of the sycamore at location CC-03 (table 6).

Although the distribution of silver maple differs from that of ash and sycamore, element correlations among silver maples also suggest some differences among sampling locations. Element correlations seem most comparable among the silver maple at location CC-04, tree SM-02 at location RR-06, and tree SM-01 at location RR-07 (table 6). Potassium was correlated with calcium or with phosphorus in each of these trees, and concentrations of most elements seemed comparable. All three trees grow relatively close together in the southwestern part of the study area. Element correlations within tree SM-01 at location RR-06 differed from the other three silver maples, however. Tree SM-01 grows near tree W-01 and about $150 \mathrm{~m}$ from tree SM-02. Iron was correlated with nicke1 in tree SM-01, and no significant correlations between nutrients were detected. This tree was similar to tree W-01, in which chromium, iron and nickel were correlated. Tree SM-02 at location RR-07 had element correlations more like the other three silver maples than like tree SM-01 at location RR-06. However, potassium was correlated with phosphorus in tree SM-01 at location RR-07 and in tree SM-02 at location RR-06; this correlation was not detected in tree SM-02 at location RR-07 presumably owing to the translocation of potassium from outer to inner sapwood rings, or possibly to large concentrations of potassium resulting from infection.

Correlations among elements in background trees suggest that location BL-08 (fig. 2) is least similar to location CC-03. In addition to various correlations among calcium, strontium, and barium, trees at location BL-08 had correlations among numerous trace metals, particularly iron, chromium, nicke1, and copper (table 6). Concentrations of some trace metals, but generally not of nutrients, were elevated in some rings of the ash and the silver maple at location BL-08 relative to some trees from the first seven sampling locations. of potassium and phosphorus, however, potassium comprised a correlative association in only one tree from location BL-08 (tree S-01, which did not contain elevated concentrations of trace metals). Correlations involving either potassium and (or) phosphorus were frequent among trees at locations CC-04, CC-05, RR-06, and RR-07 (table 6). Thus, trees at location BL-08 may grow where the availability of some trace metals is similar to that of southwestern parts of the study area, but may grow where the availability of both potassium and phosphorus is different. Only two trees from location BL-09 had a sufficient number of irradiations to permit correlation analysis, and only one tree (SM-01) could be compared to other trees of the same species from the first seven locations. 


\section{SUMRARY AND CONCLUSIONS}

Multielement analysis was performed on individual growth rings of trees growing at and near an abandoned wood-preserving plant site at Jackson, Tennessee, to determine if contaminants detected in soils, surface water, and ground water have reached areas downgradient from the site. These studies were undertaken prior to investigations of ground water in downgradient locations. Cores were collected from trees at one location near the main processing area of the site, at six downgradient locations along the western and southern boundaries of the site, and at two locations presumably unaffected by contamination. Multielement analysis by proton-induced X-ray emission was performed on 5 to 15 individual rings from each of 34 trees representing seven species and ranging in age from about 5 to 50 years.

Trees were compared on the basis of the element concentrations in three outer sapwood rings irradiated in all trees, the overall element-concentration trends of all rings irradiated, and the correlations between and among element concentrations. Element-concentration and (or) correlation differences among trees seem to reflect differences in element availability at sampling locations. The hypothesis was examined that differences in element availability in turn resulted from past activities in different areas of the site, including the construction of a levee and subsequent formation of additional lagoons, and events requiring emergency response or reclamation efforts following the closing of the facility. Broad-scale interactions between organic contaminants and natural constituents would be expected to alter the element concentrations in soils, surface waters, and ground waters, and thus to alter the availability of numerous elements for uptake by trees.

Elevated concentrations (defined as those 1.5 times greater than those in background trees) of some nutrients and trace elements in outer sapwood rings were greater and more frequent in trees sampled from the southwestern corner of the study area (locations CC-04 and CC-05) and along the railroad (locations RR-06 and RR-07) than in trees from two northwestern sampling locations ( $\mathrm{CC}-02$ and $\mathrm{CC}-03$ ) and at the former main processing area of the facility (location AS-01). Elevated concentrations of several elements in rings of trees from the southwestern locations also were elevated in water samples from the lower reaches of Central Creek and (or) from water ponded on top of the clay-capped lagoon.

Rings of trees at locations $\mathrm{CC}-02$ and $\mathrm{CC}-03$ along Central Creek contained lower concentrations of some trace metals and nutrients than those of trees at locations CC-04 and CC-05. Although trees sampled at location CC-02 are downgradient from a levee constructed in 1973 that prevents overland drainage from the most contaminated part of the site from reaching the adjacent streams, concentrations of some trace metals were greater in rings formed before than after levee construction. The greatest concentrations of these trace metals were in the 1942 ring of an oak at location CC-02, suggesting the possibility that tree growth at this location may have been affected by contamination as little as 10 years after facility operations began. There is no direct evidence that facility activities have altered the ring-element concentrations of trees growing at location CC-03.

An oak sampled at location CC-04 along the path of overland-and groundwater flow toward the South Fork Forked Deer River and Central Creek contained 
elevated concentrations of several trace metals in the 1976 ring. Concentrations of some trace metals increased to a lesser extent in the 1978 ring of a willow growing near the oak but more distant from the point of discharge to the river and Central Creek. A corresponding increase in tracemetal concentrations was not observed in the oak at location CC-02. In this regard, it would seem that element availability at locations CC-02 and CC-04 may have been different after the construction of the levee. However, it is unknown if this difference can be attributed to construction of the levee because the sycamore (S-01) sampled at location CC-05 also contained increased concentrations of some trace metals in rings that formed in the middle 1970's. Unlike in trees at CC-04, however, the concentrations of these trace metals in tree S-01 continued to increase in rings formed after 1976, as did those of a silver maple and an ash sampled at background location BL-08. An ash at location CC-05 did not contain the increased concentration trends detected in the sycamore at this location, but element correlations in the ash were strikingly different from those of the ash at location CC-03. Thus, ringelement concentrations in trees at location CC-05 seem different from those at locations $\mathrm{CC}-02$ and $\mathrm{CC}-03$, but share some similarities with trees at locations CC-04 and BL-08. It is thus unclear if tree growth at location CC-05 has been affected by processing or remediation activities at the site.

The oak at location CC-04 contained extremely large concentrations of calcium in the 1978 and 1980 rings. The timing and magnitude of these increased concentrations were detected only in the oak and did not coincide with the elevated concentrations of some trace metals in the $1976 \mathrm{ring}$. Furthermore, the distribution of calcium along the core-sample radius seems to show that translocation from outer to inner rings may have occurred. Elevated concentrations of ring calcium could have resulted from either the levee construction or the reclamation efforts in the early to middle $1980^{\prime} \mathrm{s}$.

Trees sampled along the railroad tracks at locations RR-06 and RR-07 contained ring-element concentrations differing from those sampled along Central Creek (locations CC-02, CC-03, CC-04, and CC-05). A willow at location RR-06 contained extremely large concentrations of chromium, nickel, and iron in rings formed in 1986 and thereafter; the same elements were elevated to a lesser extent but during the same time in a silver maple (SM-01) growing nearby, but not in another silver maple (SM-02) $150 \mathrm{~m}$ to the west. The elevated and sustained concentrations of trace metals in the willow and first silver maple may be due to contaminants mobilized from the storage lagoons and (or) remediation efforts in the early to middle 1980's. The trees grow about $40 \mathrm{~m}$ from the large lagoon at the southwestern corner of the site and the estimated velocity of ground water in the alluvium is about $13.4 \mathrm{~m} / \mathrm{yr}$. It also is possible that the source of contaminants is discharge into the unnamed tributary from an industrial facility to the east of the site.

Large concentrations of potassium and phosphorus were detected in the rings of some trees at location RR-07. The magnitude of potassium and phosphorus concentrations was greater than that in rings of all other sampled trees. Potassium transport into heartwood rings of two trees suggests the possibility that potassium availability increased no later than the mid to late 1970's. Because concentrations of these elements were not elevated in trees within the perimeter of the site, it seems unlikely that their source is contamination from wood-preserving operations. A possible explanation is that large concentrations of potassium and phosphorus are related to flooding. 
Baedecker, M.J., and Lindsay, S., 1986, Chapter B. Distribution of unstable constituents in ground water near a creosote works, Pensacola, Florida: In Movement and fate of creosote waste in ground water. Pensacola, Florida: U.S. Geological Survey toxic waste-ground-water contamination program, H.C. Mattraw, Jr., and B.J. Franks, eds., U.S. Geological Survey Water-Supply Paper 2285, p. 9-17.

Bennet, P., and Siege1, D.I., 1987, Increased solubility of quartz in water due to complexing by organic acids: Nature, v. 326, p. 684 .

Bondietti, E.A., Baes, C.F., III, and McLaughlin, S.B., 1989, Radial trends in cation ratios in tree rings as indicators of the impact of atmospheric deposition on forests: Canadian Journal of Forest Research, v. 19, p. 586-594.

Bradfield, A.D., Flexner, N.M., and Webster, D.A., 1993, Water quality, organic chemistry of sediments, and biological conditions of streams near an abandoned wood-preserving plant site at Jackson, Tennessee: U.S. Geological Survey Water-Resources Investigations Report 93-4148, 50 p.

Brown, W.T., Keathley, G.L., and Conner, C.T., 1978, Soil survey of Madison County, Tennessee: U.S. Department of Agriculture, Soil Conservation Service, $51 \mathrm{p}$.

Fenneman, N.M., 1938, Physiography of Eastern United States: New York, McGraw-Hi11, 714 p.

Hupp, C.R., Woodside, M.D., and Yanosky, T.M., 1993, Sediment and trace element trapping in a forested wetland, Chickahominy River, Virginia: Wetlands, v. 13, p. 95-104.

Legge, A.H., Kaufmann, H.C., and Winchester, J.W., 1984, Tree-ring analysis by PIXE for a historical record of soil chemistry response to acidic air pollution: Nuclear Instruments and Methods in Physical Research, B3, p. $507-510$.

Mattraw, H.C. Jr., and Franks, B.J., 1986, Chapter A. Description of hazardous-waste research at a creosote works, Pensacola, Florida: In Movement and fate of creosote waste in ground water, Pensacola, Florida: H.C. Mattraw, Jr., and B.J. Franks, eds., U.S. Geological Survey Water Supply Paper 2285, p. 1-8.

McClenahen, J.R., Vimmerstedt, J.P., and Scherzer, A.J., 1989, Elemental concentrations in tree rings by PIXE: Statistical variability, mobility, and effects of altered soil chamistry: Canadian Journal of Forest Research, v. 19, p. 880-888.

Milhous, H.C., 1959, Well logs in Tennessee: Tennessee Division of Geology, Bulletin 62, $606 \mathrm{p}$. 
Momoshima, N., and Bondietti, E.A., 1990, Cation binding in wood: applications to understanding historical changes in divalent cation availability in red spruce: Canadian Journal of Forest Research, v. 20, p. 1840-1849.

National Oceanic and Atmospheric Administration, 1991, Climatological data annual summary, Tennessee: v. 96 , no. 13 .

Parks, W.S., 1968, Geologic map of the Jackson South quadrangle, Tennessee: Tennessee Division of Geology GM 438-SE, scale 1:24,000.

Parks, W.S., and Carmichael, J.K., 1989, Geology and ground-water resources of the Fort Pillow Sand in western Tennessee: U.S. Geological Survey Water Resources Investigations Report 89-4120, 20 p.

Parks, W.S., Carmichael, J.K., and Mirecki, J.E., 1993, Evaluation of subsurface exploration, sampling, and water-quality-analysis methods at an abandoned wood-preserving plant site at Jackson, Tennessee: U.S. Geological Survey Water-Resources Investigations Report 93-4108, 22 p.

Phipps, R.L., 1985, Collecting, preparing, crossdating, and measuring tree increment cores: U.S. Geological Survey Water-Resources Investigations Report 85-4148, 48 p.

Russe11, E.E., and Parks, W.S., 1975, Stratigraphy of the outcropping Upper Cretaceous, Paleocene, and lower Eocene in western Tennessee (including descriptions of younger fluvial deposits): Tennessee Division of Geology Bulletin 75, $126 \mathrm{p}$.

S\&ME, Inc., 1988, Final remedial investigation report, American Creosote Works Site, Jackson, Tennessee: Prepared by S\& ME, Inc., Atlanta, Georgia, for the U.S. Army Corps of Engineers, Kansas City, Missouri (under contract no. DACW41-86-C-0104), S \& ME Document no. 8605A-0146.

Sargent, C.S., 1926, Manual of the trees of North America: Houghton Mifflin Company, Boston, $910 \mathrm{p}$.

Schneider, R.R., and Blankenship, R.E., 1950, Subsurface geologic crosssection from Claybrook, Madison County, to Memphis, Shelby County, Tennessee: Tennessee Division of Geology Ground-Water Investigations Preliminary Chart 1.

Vroblesky, D.A., and Yanosky, T.M., 1990, Use of tree-ring chemistry to document historical ground-water contamination events: Ground Water, v. 28 , p. 677-684.

Vroblesky, D.A., Yanosky, T.M., and Siegel, F.R., 1992, Increased concentrations of potassium in the heartwood of trees in response to ground-water contamination: Environmental Geology and Water Science, v. 19, p. 71-74.

Wilkinson, L., 1990, SYSTAT: the system for statistics: SYSTAT, Inc.

Yanosky, T.M., and Vroblesky, D.A., 1992, Relation of nickel concentrations in tree rings to groundwater contamination: Water Resources Research, v. 28 , p. 2077-2083. 


\section{APPENDIX}

Element concentrations in rings of trees sampled from nine locations at and near the American Creosote Works abandoned plant site at Jackson, Tennessee

[Concentrations expressed as micrograms per gram (ug/g): --, element was not detected in the sample; AS, active site; BL, "background" location; CC, Central Creek; RR, railroad tracks; A, ash; CO, cherrybark oak; CW, cottonwood; S, sycamore; SM, silver maple; W, willow; wo, willow oak.] 
A. Location AS-01

Tree CW-01

\begin{tabular}{lrrrrrrrr}
\hline YEAR & S1 & P & S & C1 & K & Ca & T1 & Cr \\
\hline 1986 & 20.0 & 101.6 & 740.8 & 76.2 & 3,210 & 1,540 & $\ldots$ & $\ldots$ \\
1987 & 49.7 & 101.0 & 721.0 & 92.7 & 3,790 & 2,170 & - & - \\
1988 & 27.0 & 85.5 & 556.5 & 55.8 & 3,620 & 2,390 & -- & 0.2 \\
1989 & 50.0 & 218.4 & 200.3 & 74.9 & 2,310 & 874 & 0.3 & 0.2 \\
1990 & 43.3 & 339.3 & 272.7 & 32.9 & 1,760 & 983 & $\ldots$ & 0.6
\end{tabular}

cont.

\begin{tabular}{rrrrrrrrr}
\hline YEAR & Mn & Fe & Ni & Cu & Zn & Sr & Ba & Pb \\
\hline 1986 & 154.9 & 14.5 & 0.4 & 3.2 & 51.5 & 23.6 & $\ldots$ & 0.6 \\
1987 & 351.9 & 12.1 & 0.8 & 2.9 & 71.9 & 22.3 & $\cdots$ & 0.2 \\
1988 & 473.5 & 10.6 & 0.5 & 2.2 & 43.1 & 22.7 & $\cdots$ & 0.6 \\
1989 & 350.5 & 9.0 & 0.3 & 2.5 & 23.4 & 9.7 & $\cdots$ & 0.4 \\
1990 & 411.0 & 10.0 & 0.1 & 1.9 & 17.5 & 7.8 & -- & 0.3 \\
\hline
\end{tabular}

Tree S-01

\begin{tabular}{lrrrrrrrr}
\hline YEAR & Si & $\mathbf{P}$ & $\mathbf{S}$ & $\mathbf{C 1}$ & $\mathbf{K}$ & $\mathbf{C a}$ & Ti & Cr \\
\hline 1987 & 40.8 & 511.9 & 657.3 & 681.5 & 3,690 & 1,150 & 2.1 & 0.1 \\
1988 & 48.8 & 407.8 & 499.2 & 449.4 & 3,490 & 1,000 & 2.3 & - \\
1989 & 40.5 & 556.8 & 407.3 & 302.4 & 3,060 & 851 & 1.3 & - \\
1990 & 60.3 & 879.7 & 349.7 & 251.9 & 2,990 & 694 & 1.4 & -
\end{tabular}

cont.

\begin{tabular}{rrrrrrrrr}
\hline YEAR & Mn & Fe & Ni & Cu & Zn & Sr & Ba & Pb \\
\hline 1987 & 11.5 & 12.0 & 0.7 & 15.0 & 3.6 & 6.7 & 3.0 & 1.1 \\
1988 & 17.4 & 9.1 & 0.3 & 5.4 & 3.6 & 5.9 & 0.8 & 1.8 \\
1989 & 16.3 & 7.9 & 0.2 & 3.6 & 2.4 & 5.5 & 1.7 & 0.9 \\
1990 & 26.7 & 13.9 & 0.5 & 4.8 & 4.3 & 4.7 & 1.3 & 0.6 \\
\hline
\end{tabular}


Tree W-01

\begin{tabular}{rrrrrrrrr}
\hline YEAR & S1 & P & S & C1 & K & Ca & T1 & Cr \\
\hline 1986 & 46.6 & 93.4 & 229.4 & 77.5 & 2,900 & 1,430 & 0.4 & - \\
1987 & -- & 47.9 & 170.0 & 43.8 & 2,270 & 1,440 & - & 0.3 \\
1988 & -- & 178.9 & 254.9 & 162.4 & 3,460 & 1,570 & - & 0.4 \\
1989 & -- & 179.4 & 181.9 & 102.2 & 1,240 & 898 & -- & 0.6 \\
1990 & -- & 404.1 & 243.9 & 58.2 & 1,100 & 868 & -- & --
\end{tabular}

cont.

\begin{tabular}{rrrrrrrrr}
\hline YEAR & Mn & Fe & N1 & Cu & Zn & Sr & Ba & Pb \\
\hline 1986 & 290.9 & 15.6 & 0.5 & 4.3 & 71.4 & 9.3 & 1.0 & 5.4 \\
1987 & 418.0 & 18.0 & 0.6 & 8.7 & 93.9 & 13.5 & - & 7.3 \\
1988 & 417.6 & 164.5 & 1.1 & 11.8 & 89.4 & 12.8 & 3.3 & 5.4 \\
1989 & 612.8 & 41.0 & 1.0 & 7.0 & 95.1 & 9.5 & - & 3.2 \\
1990 & 557.4 & 27.3 & 0.3 & 4.3 & 52.9 & 8.2 &.- & 1.6 \\
\hline
\end{tabular}

Tree W-02

\begin{tabular}{rrrrrrrrr}
\hline YEAR & S1 & $\mathbf{P}$ & S & C1 & K & Ca & TI & Cr \\
\hline 1987 & 32.5 & 180.2 & 233.9 & 33.9 & 2,630 & 745 & $\ldots$ & 0.7 \\
1988 & 59.1 & 311.1 & 250.6 & 38.9 & 1,600 & 682 & $\ldots$ & 0.8 \\
1989 & 32.2 & 280.4 & 276.2 & 122.5 & 1,420 & 654 & - & 0.3 \\
1990 & 48.1 & 433.9 & 226.3 & 234.5 & 1,650 & 603 & 1.1 & 0.7
\end{tabular}

cont.

\begin{tabular}{rrrrrrrrr}
\hline YEAR & Mn & Fe & N1 & Cu & Zn & Sr & Ba & Pb \\
\hline 1987 & 258.8 & 45.1 & 0.3 & 5.0 & 31.1 & 4.9 & 0.4 & 0.2 \\
1988 & 343.6 & 278.0 & 0.2 & 4.2 & 31.8 & 5.1 & $\ldots$ & 0.5 \\
1989 & 374.8 & 89.5 & 0.1 & 2.9 & 33.8 & 4.1 & $-\ldots$ & - \\
1990 & 237.0 & 43.1 & 0.4 & 4.4 & 21.5 & 3.9 & 0.5 & - \\
\hline
\end{tabular}


B. Location CC-02

Tree $\mathrm{CO}-01$

\begin{tabular}{rrrrrrrrr}
\hline YEAR & Si & P & S & C1 & K & Ca & TI & Cr \\
\hline 1942 & 120.8 & 60.2 & 147.5 & 43.3 & 1,370 & 643 & 0.8 & 2.3 \\
1952 & 53.5 & 54.9 & 128.1 & 28.8 & 1,040 & 627 & 1.2 & 0.6 \\
1962 & 46.4 & 46.5 & 129.7 & 17.8 & 1,350 & 681 & 1.9 & 0.5 \\
1972 & 55.0 & 56.9 & 152.2 & 26.2 & 935 & 370 & 1.2 & 0.3 \\
1978 & 19.1 & 146.4 & 128.8 &.- & 3,600 & 1,510 & 0.8 & 0.3 \\
1982 & 96.9 & 188.4 & 142.1 & 27.8 & 4,190 & 2,170 & 1.0 & 2.0 \\
1987 & 86.6 & 151.0 & 131.8 & 43.5 & 2,100 & 1,560 & 1.1 & 1.3 \\
1989 & 31.1 & 299.9 & 184.7 & 43.1 & 2,500 & 1,090 & 0.1 & 0.2 \\
1990 & 46.2 & 399.2 & 225.0 & 148.0 & 2,080 & 1,620 & 0.8 & 0.7
\end{tabular}

cont .

\begin{tabular}{rrrrrrrrr}
\hline YEAR & Mn & Fe & Ni & Cu & Zn & Sr & Ba & Pb \\
\hline 1942 & 133.2 & 287.9 & 5.3 & 4.8 & 9.1 & 6.2 & 4.0 & 1.1 \\
1952 & 125.6 & 86.8 & 2.1 & 2.9 & 6.9 & 6.9 & 4.6 & 0.9 \\
1962 & 68.6 & 59.6 & 2.4 & 2.8 & 6.9 & 7.0 & 4.6 & 0.8 \\
1972 & 28.4 & 19.2 & 0.5 & 1.5 & 4.4 & 2.7 & 2.4 & 0.6 \\
1978 & 65.8 & 15.5 & 0.8 & 1.5 & 2.2 & 5.0 & 4.8 & 0.6 \\
1982 & 146.0 & 29.1 & 2.3 & 3.2 & 5.5 & 10.5 & 9.9 & 1.7 \\
1987 & 118.5 & 27.3 & 2.9 & 4.4 & 5.5 & 9.0 & 2.4 & 1.9 \\
1989 & 103.9 & 10.6 & 1.2 & 1.9 & 2.7 & 4.6 & 3.8 & 0.5 \\
1990 & 119.0 & 26.8 & 1.5 & 3.6 & 5.8 & 7.1 & 3.4 & 0.5 \\
\hline
\end{tabular}


Tree S-01

\begin{tabular}{rrrrrrrrr}
\hline YEAR & Si & $\mathbf{P}$ & $\mathbf{S}$ & $\mathbf{C 1}$ & $\mathbf{K}$ & $\mathbf{C a}$ & $\mathbf{T} \mathbf{1}$ & $\mathbf{C r}$ \\
\hline 1985 & 147.7 & 624.0 & 388.2 & 90.3 & 3,760 & 1,400 & 16.8 & 0.8 \\
1987 & 109.4 & 659.0 & 390.5 & 112.6 & 2,330 & 1,560 & 18.9 & 0.1 \\
1989 & 112.1 & 754.1 & 262.4 & 184.2 & 1,560 & 1,070 & 8.1 & 0.6 \\
1990 & 75.4 & $1,030.0$ & 240.6 & 16.6 & 2,000 & 1,030 & 3.0 & --
\end{tabular}

cont.

\begin{tabular}{rrrrrrrrr}
\hline YEAR & Mn & Fe & Ni & Cu & Zn & Sr & Ba & Pb \\
\hline 1985 & 19.1 & 38.0 & 1.6 & 5.9 & 10.6 & 13.4 & 8.4 & 0.3 \\
1987 & 34.5 & 54.1 & 0.9 & 4.9 & 13.5 & 13.8 & -- & - \\
1989 & 10.0 & 63.4 & 0.8 & 6.2 & 12.6 & 9.3 & 6.4 & 1.2 \\
1990 & 10.9 & 31.5 & 0.6 & 6.6 & 13.2 & 10.3 & 8.8 & 1.1 \\
\hline
\end{tabular}

Tree $\mathrm{W}-01$

\begin{tabular}{rrrrrrrrr}
\hline YEAR & Si & $\mathbf{P}$ & $\mathbf{S}$ & $\mathbf{C 1}$ & $\mathbf{K}$ & $\mathbf{C a}$ & Ti & Cr \\
\hline 1983 & -- & 27.1 & 210.2 & 22.0 & 3,920 & 2,610 & -- & 0.2 \\
1984 & -- & 57.7 & 175.6 & 46.7 & 2,750 & 1,820 & 5.7 & - \\
1987 & 45.8 & 205.4 & 208.5 & 35.3 & 2,070 & 1,610 & 3.6 & -- \\
1989 & -- & 154.3 & 180.3 & 54.5 & 1,090 & 1,210 & 1.0 & 0.2 \\
1990 & 42.9 & 274.8 & 176.1 & 114.4 & 1,140 & 1,020 & -- & 0.1
\end{tabular}

cont.

\begin{tabular}{rrrrrrrrr}
\hline YEAR & Mn & Fe & Ni & Cu & Zn & Sr & Ba & Pb \\
\hline 1983 & 502.7 & 17.2 & 0.5 & 14.0 & 147.5 & 20.5 & 30.9 & 8.4 \\
1984 & 304.3 & 14.7 & 0.7 & 8.0 & 109.6 & 15.7 & -- & 8.3 \\
1987 & 184.4 & 76.6 & 0.6 & 5.9 & 115.8 & 12.6 & 20.3 & 5.0 \\
1989 & 336.0 & 14.7 & 0.7 & 4.6 & 73.1 & 13.0 & 18.1 & 0.6 \\
1990 & 319.0 & 18.2 & 1.2 & 5.1 & 50.3 & 12.9 & 16.4 & -- \\
\hline
\end{tabular}




\section{Location CC-03}

Tree A-01

\begin{tabular}{lrrrrrrrr}
\hline Year & Si & $\mathbf{P}$ & $\mathbf{S}$ & $\mathbf{C 1}$ & $\mathbf{K}$ & $\mathbf{C a}$ & $\mathbf{T 1}$ & $\mathbf{C r}$ \\
\hline 1972 & $\mathbf{8 1 . 3}$ & 120.8 & 289.1 & 30.4 & 4,721 & 1,261 & 3.8 & -- \\
1976 & 109.9 & 217.2 & 264.9 & 22.3 & 4,120 & 1,473 & 2.8 & - \\
1978 & 120.6 & 252.7 & 248.3 & 7.3 & 5,255 & 2,596 & 8.5 & - \\
1980 & 133.3 & 236.9 & 225.5 & 13.8 & 4,165 & 2,612 & 5.3 & - \\
1982 & 118.9 & 81.1 & 156.5 & 36.4 & 1,366 & 1,078 & 5.8 & - \\
1984 & 150.5 & 163.8 & 164.0 & 47.7 & 2,153 & 1,155 & 7.1 & -- \\
1987 & 132.7 & 100.9 & 114.5 & 36.9 & 1,163 & 1,037 & 7.1 & - \\
1989 & 224.0 & 642.4 & 364.7 & 173.7 & 4,270 & 1,699 & 3.0 & - \\
1990 & 118.2 & 396.4 & 196.4 & 129.5 & 1,322 & 1,243 & 5.4 & -
\end{tabular}

cont.

\begin{tabular}{lrrrrrrrr}
\hline Year & Mn & Fe & Ni & Cu & Zn & Sr & Ba & Pb \\
\hline 1972 & 2.6 & 4.8 & 1.1 & 58.5 & 17.1 & 15.5 & 25.9 & 0.1 \\
1976 & 7.0 & 8.0 & 1.2 & 57.3 & 19.8 & 18.8 & 31.8 & 0.1 \\
1978 & 7.6 & 15.2 & 3.2 & 94.2 & 33.8 & 37.6 & 59.8 & 1.9 \\
1980 & 4.2 & 16.4 & 2.2 & 67.0 & 23.8 & 38.6 & 52.5 & 2.5 \\
1982 & 1.7 & 8.7 & 1.2 & 18.9 & 16.6 & 15.8 & 21.9 & 1.1 \\
1984 & 2.3 & 15.9 & 1.2 & 17.5 & 24.8 & 14.3 & 23.6 & 0.9 \\
1987 & 4.4 & 18.7 & 1.7 & 12.0 & 21.8 & 12.3 & 26.0 & 0.5 \\
1989 & 6.8 & 13.4 & 1.2 & 13.0 & 9.2 & 17.7 & 46.3 & 0.6 \\
1990 & 6.9 & 21.3 & 1.8 & 9.2 & 23.2 & 14.5 & 30.5 & 0.6 \\
\hline
\end{tabular}


Tree S-01

\begin{tabular}{lrrrrrrrr}
\hline YEAR & Si & $\mathbf{P}$ & $\mathbf{S}$ & $\mathbf{C 1}$ & $\mathbf{K}$ & $\mathbf{C a}$ & $\mathrm{T} 1$ & $\mathbf{C r}$ \\
\hline 1972 & 149.2 & 83.8 & 409.9 & 76.0 & 1,951 & 1,993 & 5.4 & 2.6 \\
1976 & 118.0 & 83.2 & 367.6 & 86.5 & 1,721 & 1,457 & 5.0 & -- \\
1978 & 119.8 & 110.7 & 400.6 & 94.6 & 2,072 & 1,557 & 3.8 & - \\
1980 & 135.7 & 106.2 & 313.2 & 107.0 & 2,045 & 1,306 & 4.8 & -- \\
1982 & 145.1 & 67.1 & 235.4 & 234.6 & 1,468 & 999 & 6.0 & 0.4 \\
1984 & 132.5 & 312.4 & 267.7 & 127.3 & 2,354 & 1,053 & 4.1 & - \\
1987 & 86.8 & 555.3 & 217.2 & 83.2 & 2,414 & 917 & 3.5 & 0.5 \\
1989 & 118.4 & 304.2 & 225.9 & 318.5 & 1,458 & 715 & 3.5 & 0.1 \\
1990 & 102.0 & 468.3 & 250.8 & 167.1 & 2,086 & 748 & 3.7 & 0.2
\end{tabular}

cont.

\begin{tabular}{lrrrrrrrr}
\hline YEAR & Mn & Fe & Ni & Cu & Zn & Sr & Ba & Pb \\
\hline 1972 & 29.3 & 78.8 & 1.2 & 4.5 & 15.5 & 21.9 & 24.2 & 0.8 \\
1976 & 32.6 & 29.9 & 0.8 & 4.4 & 5.6 & 13.8 & 17.6 & 0.5 \\
1978 & 24.3 & 18.0 & 1.3 & 6.6 & 6.1 & 14.1 & 15.1 & 0.7 \\
1980 & 39.8 & 33.0 & 1.0 & 4.5 & 6.2 & 12.6 & 16.0 & 0.5 \\
1982 & 39.2 & 31.6 & 2.7 & 11.7 & 11.5 & 11.8 & 10.1 & 0.4 \\
1984 & 44.1 & 19.7 & 1.4 & 5.2 & 5.9 & 12.4 & 10.7 & 0.2 \\
1987 & 62.3 & 29.3 & 0.9 & 3.4 & 7.3 & 11.7 & 10.2 & 0.3 \\
1989 & 48.1 & 22.3 & 0.8 & 3.0 & 6.5 & 11.0 & 8.2 & 1.1 \\
1990 & 55.3 & 25.5 & 0.6 & 3.0 & 5.7 & 9.8 & 6.5 & 0.6 \\
\hline
\end{tabular}


D. Location CC-04

Tree C0-01

\begin{tabular}{|c|c|c|c|c|c|c|c|c|}
\hline YEAR & Si & $\mathbf{P}$ & $\mathbf{S}$ & C1 & $\mathbf{K}$ & $\mathbf{C a}$ & $T 1$ & $\mathrm{Cr}$ \\
\hline 1965 & 68.0 & 53.4 & 152.5 & 48.6 & 999 & 2,130 & 2.2 & 0.5 \\
\hline 1966 & 17.4 & 29.4 & 146.2 & 37.4 & 729 & 2,810 & 4.2 & -. \\
\hline 1971 & 75.9 & 67.0 & 171.1 & 60.6 & 877 & 1,850 & 2.3 & 0.1 \\
\hline 1972 & 27.5 & 46.1 & 124.1 & 19.8 & 710 & 1,770 & 3.1 & - \\
\hline 1976 & - & 141.8 & 155.1 & 36.0 & 4,460 & 2,640 & 0.6 & 0.8 \\
\hline 1978 & - & 107.5 & 118.1 & 24.9 & 2,660 & 10,440 & $\ldots$ & - \\
\hline 1980 & $\ldots$ & 158.9 & 143.0 & 37.5 & 5,170 & 9,970 & -. & - \\
\hline 1981 & 84.6 & 83.2 & 128.9 & 70.8 & 3,670 & 2,920 & 3.8 & \\
\hline 1983 & 67.4 & 71.8 & 122.8 & 89.4 & 3,480 & 1,620 & 3.0 & \\
\hline 1984 & 83.9 & 88.5 & 139.5 & 69.8 & 3,590 & 3,140 & 2.4 & - \\
\hline 1985 & $\ldots$ & 64.1 & 106.5 & 55.7 & 2,820 & 2,670 & 3.6 & \\
\hline 1987 & $\ldots$ & 302.6 & 176.6 & 29.6 & 4,110 & 2,100 & 0.5 & - \\
\hline 1989 & - & 254.1 & 180.2 & 30.0 & 2,720 & 2,420 & 0.9 & 0.9 \\
\hline 1990 & 57.8 & 416.9 & 354.2 & 56.3 & 2,210 & 2,420 & 1.2 & 0. \\
\hline
\end{tabular}

cont.

\begin{tabular}{rrrrrrrrr}
\hline YEAR & Mn & Fe & Ni & Cu & Zn & Sr & Ba & Pb \\
\hline 1965 & 132.9 & 106.1 & 4.2 & 13.7 & 21.8 & 14.5 & 8.3 & 3.5 \\
1966 & 141.4 & 18.5 & 2.8 & 5.5 & 10.2 & 15.0 &.- & 2.4 \\
1971 & 157.4 & 17.2 & 4.0 & 5.1 & 9.0 & 13.3 & 5.7 & 3.3 \\
1972 & 87.0 & 12.4 & 1.9 & 3.2 & 5.5 & 11.3 &.- & 1.9 \\
1976 & 212.0 & 119.7 & 4.7 & 10.2 & 14.9 & 13.7 & 6.5 & 3.9 \\
1978 & 143.3 & 69.0 & 3.0 & 7.2 & 9.9 & 48.9 & 5.9 & 3.0 \\
1980 & 152.3 & 23.7 & 3.5 & 3.9 & 6.5 & 36.5 & 7.7 & 3.1 \\
1981 & 168.7 & 19.7 & 3.0 & 3.4 & 6.7 & 9.5 &.- & 1.6 \\
1983 & 234.8 & 19.3 & 3.2 & 4.2 & 7.4 & 6.5 &.- & 1.9 \\
1984 & 208.4 & 21.2 & 2.9 & 3.4 & 6.7 & 10.7 &.- & 0.3 \\
1985 & 159.2 & 19.9 & 2.3 & 3.5 & 6.1 & 9.8 &.- & 0.7 \\
1987 & 204.7 & 37.7 & 3.5 & 4.2 & 7.6 & 10.5 & 0.7 & 1.5 \\
1989 & 224.3 & 77.2 & 3.1 & 4.2 & 8.2 & 12.1 &.- & 1.1 \\
1990 & 271.0 & 64.1 & 1.9 & 7.6 & 8.0 & 11.7 & 3.2 & 2.1 \\
\hline
\end{tabular}


Tree SM-01

\begin{tabular}{|c|c|c|c|c|c|c|c|c|}
\hline YEAR & Si & $\mathbf{P}$ & $\mathbf{s}$ & C1 & $\mathbf{K}$ & $\mathrm{Ca}$ & $T I$ & Cr \\
\hline 952 & 64.0 & 67.8 & 121.4 & 120.7 & 771 & 862 & 4.2 & $\ldots$ \\
\hline 1956 & 77.2 & 147.4 & 172.9 & 86.4 & 1,171 & 1,167 & 4.5 & 7.6 \\
\hline 1960 & 31.0 & 129.4 & 159.0 & 83.7 & 1,300 & 1,040 & 3.2 & 0.3 \\
\hline 1964 & 65.9 & 120.9 & 114.9 & 107.9 & 906 & 824 & 4.0 & 0.2 \\
\hline 1968 & 78.2 & 177.5 & 143.8 & 127.9 & 1,363 & 1,236 & 5.3 & - \\
\hline 1972 & 71.0 & 156.7 & 99.7 & 103.8 & 1,575 & 1,422 & 6.3 & - \\
\hline 1976 & 50.0 & 225.9 & 93.8 & 181.8 & 1,620 & 1,296 & 5.2 & - \\
\hline 1980 & 62.7 & 317.8 & 117.2 & 95.3 & 2,246 & 1,435 & 6.0 & - \\
\hline 1982 & 54.1 & 264.1 & 104.0 & 110.8 & 1,908 & 1,431 & 4.3 & - \\
\hline 1984 & 41.4 & 274.4 & 90.2 & 76.0 & 1,445 & 1,204 & 5.0 & \\
\hline 1987 & 64.8 & 278.2 & 141.5 & 141.1 & 1,380 & 1,254 & 4.8 & - \\
\hline 1989 & 62.0 & 245.6 & 136.7 & 146.4 & 1,281 & 1,395 & 8.4 & 2.1 \\
\hline 1990 & 67.9 & 311.1 & 119.8 & 85.7 & 1,434 & 1,161 & 5.8 & \\
\hline
\end{tabular}

cont.

\begin{tabular}{lrrrrrrrr}
\hline YEAR & Mn & Fe & Ni & Cu & Zn & Sr & Ba & Pb \\
\hline 1952 & 37.1 & 11.7 & 0.7 & 1.8 & 13.3 & 9.2 & 21.8 &.- \\
1956 & 46.7 & 53.4 & 3.4 & 2.6 & 17.7 & 12.2 & 39.1 & 0.5 \\
1960 & 40.8 & 19.9 & 0.4 & 2.7 & 13.8 & 10.8 & 33.2 & 0.2 \\
1964 & 34.2 & 23.2 & 0.4 & 1.5 & 11.0 & 9.2 & 21.1 & $\ldots$ \\
1968 & 68.4 & 26.8 & 0.3 & 2.5 & 13.7 & 15.5 & 34.3 & $\ldots$ \\
1972 & 79.3 & 41.3 & 0.4 & 2.5 & 18.8 & 18.5 & 41.5 & $\ldots$ \\
1976 & 64.5 & 14.0 & 0.3 & 2.8 & 17.1 & 16.7 & 33.1 & $\ldots$ \\
1980 & 61.6 & 29.5 & 0.5 & 3.0 & 23.4 & 16.7 & 38.4 & - \\
1982 & 65.6 & 16.3 & 0.6 & 2.9 & 19.7 & 16.2 & 38.0 & 0.1 \\
1984 & 53.5 & 21.9 & 0.4 & 2.3 & 12.2 & 14.0 & 30.5 & 0.1 \\
1987 & 67.4 & 76.8 & 1.2 & 3.6 & 13.3 & 15.9 & 29.9 & - \\
1989 & 68.4 & 62.5 & 2.0 & 4.0 & 18.0 & 16.6 & 30.0 & 0.4 \\
1990 & 53.6 & 44.0 & 0.6 & 4.2 & 12.1 & 13.1 & 32.2 & 0.3 \\
\hline
\end{tabular}


Tree W-01

\begin{tabular}{lrrrrrrrr}
\hline YEAR & SI & $\mathbf{P}$ & $\mathbf{S}$ & $\mathbf{C 1}$ & $\mathbf{K}$ & $\mathbf{C a}$ & TI & Cr \\
\hline 1972 & 34.5 & 141.1 & 223.7 & 144.0 & 1,840 & 2,630 & 1.4 & - \\
1976 & 38.3 & 139.8 & 227.2 & 60.6 & 1,220 & 1,640 & 1.4 & 1.6 \\
1978 & 65.0 & 157.7 & 239.2 & 92.0 & 1,040 & 1,590 & 3.8 & 5.6 \\
1982 & 50.3 & 269.0 & 241.4 & 110.1 & 2,320 & 1,120 & 3.3 & 0.7 \\
1987 & 62.7 & 358.9 & 275.8 & 61.0 & 1,570 & 1,280 & 1.3 & 5.2 \\
1989 & 38.7 & 294.3 & 282.4 & 68.2 & 1,780 & 1,070 & 0.8 & 3.2 \\
1990 & 32.1 & 303.2 & 246.1 & 85.2 & 1,780 & 1,040 & 2.9 & 4.8
\end{tabular}

cont.

\begin{tabular}{rrrrrrrrr}
\hline YEAR & Mn & Fe & Ni & Cu & Zn & Sr & Ba & Pb \\
\hline 1972 & 286.5 & 319.9 & 1.4 & 4.5 & 61.3 & 12.5 & 16.7 & 35.4 \\
1976 & 193.0 & 318.8 & 0.9 & 6.3 & 44.8 & 10.1 & 13.7 & 0.3 \\
1978 & 187.9 & 439.7 & 2.7 & 7.9 & 50.7 & 10.1 & 18.6 & 0.3 \\
1982 & 97.2 & 336.6 & 1.2 & 4.6 & 44.4 & 7.7 & 15.8 & 2.4 \\
1987 & 189.8 & 790.4 & 2.4 & 14.2 & 93.6 & 12.4 & 18.9 & 0.2 \\
1989 & 120.2 & 203.7 & 1.7 & 11.0 & 62.8 & 9.6 & 18.3 &.- \\
1990 & 151.2 & 115.8 & 2.3 & 9.7 & 54.7 & 9.4 & 15.8 & 0.3 \\
\hline
\end{tabular}


E. Location CC-05

Tree A-01

\begin{tabular}{lrrrrrrrr}
\hline YEAR & $\mathbf{S} \mathbf{I}$ & $\mathbf{P}$ & $\mathbf{S}$ & $\mathbf{C 1}$ & $\mathbf{K}$ & $\mathbf{C a}$ & $\mathbf{T} \mathbf{C}$ & $\mathbf{C r}$ \\
\hline 1948 & 101.2 & 61.7 & 238.1 & 24.8 & 2,826 & 1,191 & 4.0 & $\ldots$ \\
1952 & 95.8 & 108.9 & 301.6 & 64.2 & 4,032 & 1,402 & 8.1 & $\ldots$ \\
1956 & 135.5 & 166.7 & 303.4 & 71.7 & 3,828 & 1,301 & 4.2 & $\ldots$ \\
1960 & 90.6 & 73.3 & 210.0 & 44.5 & 2,238 & 1,129 & 5.9 & $\ldots$ \\
1964 & 237.4 & 122.0 & 307.8 & 102.3 & 3,776 & 1,381 & 6.8 & $\ldots$ \\
1968 & 190.6 & 117.6 & 236.9 & 65.3 & 3,129 & 1,029 & 5.5 & 0.2 \\
1972 & 75.0 & 54.3 & 147.3 & 26.6 & 1,830 & 962 & 3.5 & 0.2 \\
1976 & 96.1 & 156.8 & 276.9 & 79.2 & 3,108 & 1,493 & 4.1 & $\ldots$ \\
1978 & 141.2 & 139.8 & 217.2 & 66.9 & 2,541 & 1,296 & 13.1 & $\ldots$ \\
1980 & 103.6 & 127.0 & 173.6 & 48.4 & 2,119 & 1,163 & 2.9 & $\ldots$ \\
1982 & 101.6 & 158.1 & 159.7 & 42.5 & 2,285 & 1,331 & 5.5 & $\ldots$ \\
1984 & 73.8 & 204.7 & 138.2 & 10.5 & 2,828 & 994 & 3.3 & $\ldots$ \\
1987 & 62.4 & 388.8 & 172.3 & 32.2 & 2,675 & 1,242 & 5.2 & $\ldots$ \\
1989 & 81.7 & 410.4 & 173.1 & 48.1 & 1,418 & 1,205 & 4.6 & $\ldots$ \\
1990 & 66.0 & 629.7 & 187.9 & 36.4 & 1,830 & 1,030 & 3.9 & $\ldots$ \\
& & & & & & & &
\end{tabular}

cont .

\begin{tabular}{rrrrrrrrr}
\hline YEAR & Mn & Fe & NI & Cu & Zn & Sr & Ba & Pb \\
\hline 1948 & 1.3 & 17.9 & 1.2 & 48.2 & 12.0 & 28.7 & 100.4 & $\ldots$ \\
1952 & 1.3 & 32.1 & 1.0 & 50.8 & 12.6 & 29.0 & 113.1 & $\ldots$ \\
1956 & 1.4 & 19.4 & 1.0 & 46.0 & 15.6 & 27.4 & 112.8 & 0.4 \\
1960 & 1.1 & 26.3 & 1.2 & 42.2 & 13.7 & 28.8 & 105.4 & $\ldots$ \\
1964 & 1.7 & 31.2 & 1.2 & 51.3 & 19.4 & 28.4 & 98.2 & 0.4 \\
1968 & 1.0 & 27.4 & 1.2 & 39.9 & 28.4 & 19.6 & 67.0 & $\ldots$ \\
1972 & 1.3 & 15.7 & 0.5 & 36.4 & 10.0 & 20.2 & 65.5 & $\ldots$ \\
1976 & 2.5 & 39.8 & 1.6 & 62.7 & 12.3 & 30.5 & 85.0 & $\ldots$ \\
1978 & 1.6 & 31.9 & 1.1 & 42.1 & 17.7 & 24.8 & 53.4 & $\ldots$ \\
1980 & 1.8 & 27.5 & 1.7 & 27.4 & 5.6 & 17.6 & 46.9 & 0.2 \\
1982 & 2.3 & 24.3 & 0.4 & 24.4 & 12.2 & 22.1 & 59.7 & 0.1 \\
1984 & 2.8 & 9.5 & 0.6 & 15.1 & 7.8 & 17.5 & 53.0 & 0.1 \\
1987 & 5.3 & 12.1 & 1.3 & 12.6 & 5.7 & 19.9 & 53.1 &.- \\
1989 & 4.6 & 16.4 & 1.2 & 12.3 & 6.1 & 24.4 & 60.7 & 0.5 \\
1990 & 3.3 & 21.2 & 1.3 & 8.3 & 8.0 & 17.6 & 48.9 & 0.5 \\
\hline
\end{tabular}




\begin{tabular}{rrrrrrrrr}
\hline YEAR & $\mathbf{S 1}$ & $\mathbf{P}$ & $\mathbf{S}$ & $\mathbf{C 1}$ & $\mathbf{K}$ & $\mathbf{C a}$ & $\mathbf{T} \mathbf{C}$ & $\mathbf{C r}$ \\
\hline 1948 & 199.8 & 35.3 & 432.4 & 341.5 & 4,438 & 4,301 & 4.3 & 11.3 \\
1952 & 174.3 & -- & 274.2 & 106.3 & 3,270 & 5,526 & 6.6 & 12.6 \\
1956 & 177.6 & 46.7 & 280.7 & 186.5 & 3,135 & 2,724 & 4.9 & 1.0 \\
1960 & 123.3 & 21.2 & 226.2 & 167.3 & 1,600 & 2,330 & 8.5 & 0.2 \\
1964 & 156.4 & 73.6 & 320.6 & 122.1 & 2,017 & 3,732 & 3.1 & -1 \\
1968 & 292.0 & 94.1 & 554.9 & 169.5 & 2,141 & 2,320 & 11.6 & 0.6 \\
1972 & 116.8 & 130.8 & 633.0 & 69.7 & 2,823 & 1,994 & 3.2 & 0.6 \\
1976 & 122.0 & 95.8 & 299.6 & 103.3 & 1,342 & 1,487 & 6.2 & 3.2 \\
1978 & 187.2 & 101.0 & 264.8 & 69.2 & 1,206 & 1,569 & 10.1 & 4.0 \\
1980 & 168.8 & 100.6 & 246.6 & 176.7 & 1,388 & 1,304 & 9.6 & 6.7 \\
1982 & 137.5 & 102.3 & 222.6 & 71.0 & 1,681 & 1,249 & 6.5 & 5.6 \\
1984 & 125.2 & 213.5 & 274.1 & 29.1 & 2,102 & 2,300 & 6.3 & 1.4 \\
1987 & 152.6 & 197.2 & 218.3 & 151.7 & 1,270 & 1,880 & 4.4 & 16.0 \\
1989 & 95.3 & 350.2 & 209.8 & 71.1 & 1,223 & 3,171 & 7.0 & 2.9 \\
1990 & 133.4 & 419.2 & 220.9 & 97.7 & 1,385 & 3,269 & 7.4 & 10.8
\end{tabular}

cont.

\begin{tabular}{rrrrrrrrr}
\hline YEAR & Mn & Fe & N1 & Cu & Zn & Sr & Ba & Pb \\
\hline 1948 & 31.0 & 205.3 & 7.8 & 10.7 & 19.5 & 66.9 & 46.7 & 1.0 \\
1952 & 112.0 & 71.9 & 16.0 & 19.4 & 11.0 & 94.2 & 65.2 & 3.3 \\
1956 & 18.2 & 89.9 & 3.5 & 9.3 & 11.1 & 30.0 & 14.8 & 0.4 \\
1960 & 17.9 & 64.5 & 2.9 & 11.8 & 19.6 & 33.0 & 4.2 & -- \\
1964 & 21.4 & 53.1 & 2.4 & 7.2 & 11.6 & 43.4 & 55.7 & 0.3 \\
1968 & 21.9 & 97.7 & 1.3 & 3.3 & 8.9 & 24.2 & 20.4 & 0.9 \\
1972 & 32.7 & 124.7 & 2.7 & 3.4 & 7.9 & 25.7 & 30.1 & 0.5 \\
1976 & 25.5 & 370.7 & 3.4 & 6.5 & 20.2 & 23.1 & 13.2 & - \\
1978 & 27.2 & 495.1 & 3.9 & 5.1 & 37.5 & 25.0 & 6.6 & 0.6 \\
1980 & 21.7 & 644.0 & 4.8 & 6.9 & 41.3 & 20.4 & 3.3 & 0.7 \\
1982 & 18.2 & 393.7 & 4.0 & 5.1 & 29.7 & 17.4 & 8.0 & 0.9 \\
1984 & 25.1 & 302.9 & 4.2 & 5.4 & 15.8 & 29.8 & -- & - \\
1987 & 19.5 & 1190.0 & 7.9 & 6.3 & 18.9 & 18.9 &.- & 10.6 \\
1989 & 15.1 & 538.2 & 4.7 & 5.1 & 9.6 & 36.7 & -- & -- \\
1990 & 18.0 & 1121.0 & 6.3 & 7.6 & 10.6 & 35.0 & -- & 5.0 \\
\hline
\end{tabular}


F. Location RR-06

Tree SM-01

\begin{tabular}{lrrrrrrrr}
\hline YEAR & Si & P & S & C1 & K & Ca & TI & Cr \\
\hline 1978 & 70.0 & 179.2 & 143.6 & 116.1 & 2,108 & 1,250 & 3.9 & - \\
1980 & 47.3 & 125.1 & 111.2 & 114.2 & 1,430 & 1,240 & 3.3 & - \\
1982 & 77.6 & 96.9 & 81.8 & 106.7 & 923 & 774 & 3.3 & - \\
1984 & 58.4 & 183.8 & 111.6 & 89.2 & 1,442 & 1,004 & 3.4 & - \\
1987 & 210.8 & 151.5 & 99.7 & 160.2 & 1,310 & 1,059 & 6.9 & 2.4 \\
1989 & 61.8 & 218.8 & 126.4 & 94.2 & 1,273 & 622 & 1.8 & 0.6 \\
1990 & 70.2 & 299.3 & 124.0 & 65.1 & 1,343 & 513 & 4.3 & 0.6
\end{tabular}

cont.

\begin{tabular}{rrrrrrrrr}
\hline YEAR & Mn & Fe & N1 & Cu & Zn & Sr & Ba & Pb \\
\hline 1978 & 112.8 & 11.0 & 0.1 & 2.5 & 17.4 & 12.7 & 3.8 & 0.7 \\
1980 & 157.9 & 7.4 & 0.2 & 2.2 & 15.6 & 12.7 & 7.9 & 0.3 \\
1982 & 126.4 & 13.1 & 0.5 & 2.1 & 15.4 & 9.5 & -- &.- \\
1984 & 106.4 & 12.5 & 0.3 & 2.7 & 18.8 & 10.9 & 2.9 & -- \\
1987 & 96.3 & 149.1 & 3.2 & 5.1 & 26.8 & 14.8 & -- & 0.2 \\
1989 & 69.2 & 71.0 & 1.5 & 2.8 & 10.4 & 8.4 & -- & - \\
1990 & 40.6 & 12.9 & 1.1 & 2.7 & 10.4 & 7.6 & -- & -- \\
\hline
\end{tabular}




\begin{tabular}{lrrrrrrrr}
\hline YEAR & $\mathbf{S 1}$ & $\mathbf{P}$ & $\mathbf{S}$ & $\mathbf{C 1}$ & $\mathbf{K}$ & $\mathbf{C a}$ & $\mathbf{T} 1$ & $\mathbf{C r}$ \\
\hline 1956 & 90.8 & 84.0 & 99.0 & 30.4 & 1,293 & 1,066 & 3.6 & 0.6 \\
1960 & 43.1 & 92.3 & 96.6 & 50.7 & 689 & 662 & 2.6 & 0.6 \\
1964 & 38.1 & 84.0 & 98.1 & 84.4 & 832 & 826 & 3.6 & 0.3 \\
1968 & 46.3 & 98.2 & 109.0 & 84.4 & 930 & 822 & 2.2 & 0.2 \\
1972 & 63.6 & 89.6 & 98.4 & 83.1 & 775 & 859 & 3.0 & 1.2 \\
1976 & 99.7 & 123.2 & 140.4 & 140.3 & 1,217 & 938 & 3.4 & 1.0 \\
1978 & 77.7 & 66.4 & 94.2 & 96.5 & 805 & 679 & 3.4 & 0.9 \\
1980 & 83.8 & 110.7 & 123.7 & 81.3 & 1,099 & 1,008 & 2.5 & 0.5 \\
1982 & 162.8 & 166.7 & 102.3 & 59.9 & 1,585 & 959 & 3.5 & 1.0 \\
1984 & 48.0 & 98.2 & 99.8 & 67.7 & 1,064 & 710 & 3.9 & 0.2 \\
1987 & 86.7 & 103.0 & 87.1 & 61.4 & 841 & 587 & 4.6 &.- \\
1989 & 64.8 & 222.7 & 111.1 & 39.1 & 1,867 & 1,002 & 3.6 & 0.2 \\
1990 & 47.2 & 155.0 & 93.0 & 59.8 & 1,289 & 785 & 4.5 & 0.4
\end{tabular}

cont.

\begin{tabular}{rrrrrrrrr}
\hline YEAR & Mn & Fe & N1 & Cu & Zn & Sr & Ba & Pb \\
\hline 1956 & 69.1 & 28.1 & 0.3 & 1.5 & 13.4 & 9.9 & 22.2 & 0.5 \\
1960 & 64.1 & 13.7 & 0.3 & 1.2 & 14.8 & 9.9 & 17.8 & $\ldots$ \\
1964 & 64.9 & 11.9 & 0.3 & 1.4 & 16.3 & 9.2 & 17.3 & 0.3 \\
1968 & 54.6 & 16.5 & 0.1 & 7.0 & 14.4 & 7.8 & 17.9 &.- \\
1972 & 57.2 & 18.8 & 0.6 & 1.6 & 17.7 & 10.2 & 15.5 & 0.1 \\
1976 & 36.5 & 24.9 & 1.0 & 1.9 & 17.0 & 8.6 & 13.9 & $\ldots$ \\
1978 & 27.1 & 52.7 & 0.6 & 2.0 & 10.2 & 7.7 & 5.8 & 0.5 \\
1980 & 33.4 & 25.7 & 0.8 & 1.6 & 13.1 & 8.7 & 6.8 & $\ldots$ \\
1982 & 19.4 & 41.7 & 0.7 & 2.9 & 20.4 & 8.2 & 7.8 & 0.1 \\
1984 & 17.3 & 10.4 & 0.1 & 1.5 & 7.5 & 8.0 & 1.4 & 0.2 \\
1987 & 18.1 & 36.9 & 0.5 & 1.8 & 15.0 & 6.5 &.- & $\ldots$ \\
1989 & 26.5 & 23.2 & 0.3 & 2.3 & 11.1 & 8.5 & 5.5 &.- \\
1990 & 26.1 & 26.1 & 0.5 & 2.6 & 8.4 & 9.0 & 3.7 & $\ldots$ \\
\hline
\end{tabular}


Tree W-01

\begin{tabular}{rrrrrrrrr}
\hline IRAR & $\mathbf{S 1}$ & $\mathbf{P}$ & $\mathbf{S}$ & $\mathbf{C 1}$ & $\mathbf{K}$ & $\mathbf{C a}$ & $\mathbf{T} 1$ & $\mathbf{C r}$ \\
\hline 1976 & 46.8 & 57.7 & 231.4 & 114.2 & 3,380 & 1,960 & -- & 3.4 \\
1977 & 71.4 & 27.6 & 195.4 & 94.7 & 3,330 & 2,150 & 3.4 & 0.4 \\
1978 & -- & 86.4 & 277.5 & 84.6 & 3,320 & 1,860 & -- & 0.7 \\
1979 & 73.0 & 29.3 & 201.4 & 113.8 & 2,500 & 1,620 & 1.8 & 0.7 \\
1980 & -- &.- & 199.7 & 319.8 & 3,270 & 1,860 & 3.7 & 1.0 \\
1981 & 93.4 & 44.6 & 255.3 & 193.7 & 2,880 & 1,140 & 6.0 & 1.0 \\
1982 &.- & 171.0 & 274.6 & 41.5 & 2,850 & 1,070 & 0.5 & 2.6 \\
1983 & 82.5 & 94.6 & 246.5 & 80.1 & 1,730 & 1,170 & 3.0 & 2.5 \\
1984 & 71.4 & 98.3 & 227.9 & 41.8 & 1,580 & 1,120 &.- & 0.9 \\
1985 & 84.7 & 103.8 & 226.2 & 85.9 & 1,400 & 1,020 & 0.9 & 1.9 \\
1986 & 91.0 & 110.7 & 277.0 & 120.0 & 1,430 & 1,050 & 6.3 & 4.8 \\
1987 & 134.7 & 133.4 & 276.2 & 178.4 & 1,450 & 1,020 & 8.7 & 10.9 \\
1988 & 100.3 & 175.3 & 244.3 & 98.6 & 1,420 & 894 & 0.8 & 32.7 \\
1989 & 96.1 & 275.7 & 313.1 & 151.3 & 1,840 & 1,010 &.- & 21.6 \\
1990 & 41.7 & 291.3 & 220.7 & 211.6 & 1,560 & 974 & 4.1 & 10.7
\end{tabular}

cont.

\begin{tabular}{|c|c|c|c|c|c|c|c|c|}
\hline YEAR & Mn & Fe & NI & $\mathbf{C u}$ & $\mathrm{Zn}$ & Sr & $\mathrm{Ba}$ & $\mathbf{P b}$ \\
\hline 1976 & 323.9 & 212.6 & 1.7 & 11.2 & 61.1 & 19.1 & 5.6 & 1.0 \\
\hline 1977 & 402.1 & 166.3 & 1.3 & 12.9 & 40.8 & 17.5 & $\ldots$ & 0.5 \\
\hline 1978 & 286.5 & 48.6 & 1.0 & 10.5 & 81.9 & 18.5 & 7.9 & 0.5 \\
\hline 1979 & 271.1 & 61.6 & 1.5 & 13.5 & 370 & 15.3 & - & 0.8 \\
\hline 1980 & 314.3 & 236.0 & 1.9 & 5.4 & 70.3 & 17.0 & - & 0.2 \\
\hline 1981 & 171.7 & 191.7 & 1.6 & 5.0 & 62.8 & 11.6 & $\ldots$ & -. \\
\hline 1982 & 146.7 & 238.5 & 1.5 & 6.1 & 49.0 & 13.7 & $\ldots$ & 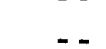 \\
\hline 1983 & 194.2 & 186.0 & 1.9 & 3.5 & 51.5 & 12.6 & $\ldots$ & $\ldots$ \\
\hline 1984 & 246.1 & 200.1 & 1.4 & 4.1 & 38.3 & 13.6 & - & - \\
\hline 1985 & 277.1 & 258.4 & 1.1 & 3.1 & 35.8 & 12.7 & - & 0.9 \\
\hline 1986 & 298.9 & 475.6 & 2.1 & 6.4 & 49.8 & 12.8 & $\ldots$ & - \\
\hline 1987 & 273.6 & $1,110.0$ & 3.0 & 4.5 & 52.7 & 13.6 & -. & 10.3 \\
\hline 1988 & 197.0 & $2,090.0$ & 6.9 & 5.8 & 39.0 & 12.5 & $\ldots$ & 0.3 \\
\hline 1989 & 236.5 & $1,610.0$ & 4.9 & 6.9 & 52.5 & 14.1 & $\ldots$ & 0.7 \\
\hline 1990 & 181.6 & 847.0 & 2.5 & 6.0 & 31.0 & 11.2 & $\ldots$ & 0.2 \\
\hline
\end{tabular}


G. Location RR-07

Tree A-01

\begin{tabular}{rrrrrrrrr}
\hline YEAR & $\mathbf{S 1}$ & $\mathbf{P}$ & $\mathbf{S}$ & $\mathbf{C 1}$ & $\mathbf{K}$ & $\mathbf{C a}$ & $\mathbf{T} \mathbf{C}$ & $\mathbf{C r}$ \\
\hline 1948 & 136.5 & 49.1 & 241.4 & 55.0 & 2,155 & 954 & 6.7 & 0.9 \\
1952 & 58.8 & 69.2 & 257.2 & 19.7 & 2,909 & 921 & 2.1 & 0.4 \\
1956 & 90.1 & 75.2 & 219.0 & 31.9 & 2,491 & 737 & 3.4 & $\ldots$ \\
1960 & 59.2 & 50.7 & 149.3 & 16.7 & 1,534 & 1,342 & 4.5 & $\ldots$ \\
1964 & 64.1 & 55.2 & 137.9 & 17.8 & 2,126 & 1,282 & 4.0 & $\ldots$ \\
1968 & 62.7 & 69.2 & 133.3 & 10.9 & 2,043 & 1,302 & 5.2 & $\ldots$ \\
1972 & 120.8 & 177.4 & 298.4 & 84.2 & 2,728 & 1,342 & 8.5 & - \\
1976 & 64.8 & 68.4 & 165.3 & 49.2 & 1,185 & 1,206 & 4.3 & $\ldots$ \\
1978 & 80.6 & 114.3 & 183.9 & 28.1 & 1,779 & 1,436 & 4.9 & $\ldots$ \\
1980 & 59.9 & 83.7 & 190.6 & 44.1 & 1,195 & 888 & 4.2 & $\ldots$ \\
1982 & 98.5 & 118.0 & 175.2 & 17.4 & 1,109 & 849 & 3.7 & - \\
1984 & 66.8 & 132.0 & 187.8 & 21.7 & 1,424 & 805 & 2.4 & 0.1 \\
1987 & 35.0 & 204.4 & 180.1 & 6.0 & 2,630 & 1,440 & 4.1 & $\ldots$ \\
1989 & 82.2 & 144.7 & 196.3 & 87.0 & 1,646 & 659 & 4.5 & $\ldots$ \\
1990 & 119.0 & 240.0 & 214.0 & 151.3 & 2,220 & 622 & 5.1 & 0.7
\end{tabular}

cont.

\begin{tabular}{|c|c|c|c|c|c|c|c|c|}
\hline YEAR & Mn & $\mathrm{Fe}$ & $\mathrm{NI}$ & Cu & $\mathrm{Zn}$ & Sr & $\mathrm{Ba}$ & $\mathrm{Pb}$ \\
\hline 1948 & 1.5 & 38.8 & 1.8 & 63.6 & 16.5 & 19.6 & 23.6 & 0.3 \\
\hline 1952 & 1.0 & 9.1 & 0.6 & 49.8 & 5.2 & 15.9 & 29.8 & - \\
\hline 1956 & 1.0 & 11.7 & 0.8 & 42.1 & 10.2 & 15.3 & 20.4 & -. \\
\hline 1960 & 1.5 & 13.3 & 1.2 & 80.9 & 10.4 & 43.6 & 55.5 & $\ldots$ \\
\hline 1964 & 2.0 & 10.1 & 1.1 & 43.7 & 7.9 & 31.9 & 57.1 & - \\
\hline 1968 & 2.0 & 7.9 & 0.8 & 56.5 & 5.9 & 32.8 & 72.6 & - \\
\hline 1972 & 4.8 & 45.5 & 1.8 & 121.7 & 12.0 & 37.0 & 81.2 & $\ldots$ \\
\hline 1976 & 2.2 & 38.2 & 2.1 & 115.0 & 11.1 & 33.0 & 102.0 & -. \\
\hline 1978 & 2.1 & 14.6 & 1.5 & 99.3 & 8.1 & 28.7 & 92.1 & 0.2 \\
\hline 1980 & 1.5 & 8.0 & 0.8 & 49.3 & 10.9 & 13.3 & 39.4 & -. \\
\hline 1982 & 2.4 & 11.1 & 0.6 & 42.5 & 9.2 & 14.7 & 44.5 & 0.2 \\
\hline 1984 & 4.1 & 9.9 & 1.2 & 31.1 & 9.7 & 14.5 & 49.1 & -. \\
\hline 1987 & 6.9 & 16.5 & 2.2 & 53.8 & 8.8 & 36.3 & 109.1 & 0.1 \\
\hline 1989 & 3.4 & 21.8 & 1.1 & 15.2 & 8.8 & 12.6 & 3.9 & -. \\
\hline 1990 & 2.5 & 27.9 & 1.7 & 14.0 & 8.1 & 10.2 & 30.9 & 0.6 \\
\hline
\end{tabular}


Tree A-02

\begin{tabular}{|c|c|c|c|c|c|c|c|c|}
\hline YEAR & $\mathbf{S i}$ & $\mathbf{P}$ & $\mathbf{s}$ & Cl & $\mathbf{K}$ & $\mathbf{C a}$ & $\mathbf{T} \mathbf{i}$ & Cr \\
\hline 1964 & 99.4 & 126.0 & 493.1 & 109.3 & 6,945 & 2,157 & 5.7 & $\cdots$ \\
\hline 1968 & 177.3 & 121.2 & 384.5 & 21.1 & 6,302 & 2,139 & 6.9 & $\cdots$ \\
\hline 1972 & 121.9 & 61.0 & 281.3 & 71.0 & 2,930 & 861 & 3.8 & -- \\
\hline 1976 & 147.1 & 101.4 & 272.6 & 11.8 & 3,153 & 1,057 & 4.9 & $\cdots$ \\
\hline 1978 & 116.0 & 64.3 & 200.7 & 37.4 & 1,709 & 772 & 4.0 & $\cdots$ \\
\hline 1980 & 104.9 & 90.9 & 221.7 & 38.8 & 2,208 & 877 & 4.6 & $\cdots$ \\
\hline 1982 & 277.3 & 113.6 & 198.1 & 35.8 & 1,926 & 874 & 7.2 & -- \\
\hline 1984 & 97.2 & 157.4 & 228.0 & 28.2 & 2,800 & 1,100 & 4.2 & -. \\
\hline 1987 & 1152.0 & 735.9 & 703.3 & 87.0 & 9,641 & 1,562 & 6.8 & 0.2 \\
\hline 1989 & 184.4 & 355.8 & 147.4 & 11.1 & 2,877 & 1,162 & 5.3 & $\cdots$ \\
\hline 1990 & 604.6 & 327.8 & 181.3 & 60.2 & 1,959 & 1,120 & 8.2 & 5 \\
\hline
\end{tabular}

cont.

\begin{tabular}{lrrrrrrrr}
\hline YEAR & Mn & Fe & Ni & Cu & Zn & Sr & Ba & Pb \\
\hline 1964 & 2.5 & 10.3 & 1.0 & 102.4 & 82.2 & 41.7 & 170.8 & $\ldots$ \\
1968 & 3.0 & 15.9 & 1.6 & 114.4 & 85.8 & 42.8 & 167.4 & $\ldots$ \\
1972 & 0.8 & 8.8 & 0.5 & 47.0 & 30.0 & 13.1 & 60.3 &.- \\
1976 & 2.5 & 14.8 & 0.6 & 77.7 & 24.6 & 18.9 & 76.7 & 0.1 \\
1978 & 1.4 & 7.2 & 0.5 & 69.5 & 16.8 & 14.4 & 58.0 & $\ldots$ \\
1980 & 2.2 & 6.0 & 0.6 & 75.5 & 16.8 & 13.8 & 61.3 & 0.3 \\
1982 & 7.4 & 34.5 & 0.5 & 59.9 & 15.1 & 13.9 & 60.5 & $\ldots$ \\
1984 & 1.3 & 4.8 & 0.3 & 62.4 & 6.9 & 15.3 & 64.1 & $\ldots$ \\
1987 & 4.8 & 23.2 & 0.7 & 43.1 & 4.3 & 17.4 & 74.6 &.- \\
1989 & 7.6 & 17.7 & 0.6 & 21.0 & 5.0 & 16.5 & 71.1 & 0.1 \\
1990 & 9.2 & 42.9 & 0.9 & 15.6 & 7.2 & 14.2 & 60.2 & 0.3 \\
\hline
\end{tabular}




\begin{tabular}{lrrrrrrrr}
\hline YEAR & S1 & $\mathbf{P}$ & $\mathbf{S}$ & $\mathbf{C 1}$ & $\mathbf{K}$ & $\mathbf{C a}$ & T1 & Cr \\
\hline 1948 & 112.2 & 70.3 & 196.0 & 55.1 & 1,952 & 1,349 & 3.3 & $\ldots$ \\
1952 & 118.8 & 79.3 & 187.8 & 52.5 & 1,437 & 1,660 & 6.7 & $\ldots$ \\
1956 & 154.8 & 83.5 & 212.4 & 106.9 & 1,527 & 1,328 & 8.2 & $\ldots$ \\
1960 & 127.8 & 88.4 & 166.7 & 44.7 & 1,676 & 1,516 & 3.2 & 1.1 \\
1964 & 104.0 & 95.8 & 196.8 & 40.9 & 1,582 & 1,531 & 4.3 & $\ldots$ \\
1968 & 102.3 & 85.8 & 143.9 & 121.8 & 1,252 & 1,669 & 4.8 & $\ldots$ \\
1972 & 118.6 & 118.1 & 204.6 & 216.7 & 1,601 & 1,844 & 5.8 & $\ldots$ \\
$1977 / 80^{*}$ & 107.5 & 186.1 & 187.2 & 49.1 & 2,377 & 1,699 & 4.2 & $\ldots$ \\
$982 / 84^{*}$ & 152.7 & 135.0 & 176.8 & 90.8 & 1,195 & 1,567 & 17.2 & $\ldots$ \\
$1985 / 89^{*}$ & 117.5 & 702.5 & 311.0 & 63.1 & 2,705 & 2,676 & 3.8 & $\ldots$
\end{tabular}

cont.

\begin{tabular}{rrrrrrrrr}
\hline YEAR & Mn & Fe & Ni & Cu & Zn & Sr & Ba & Pb \\
\hline 1948 & 1.2 & 21.3 & 0.5 & 7.9 & 6.1 & 28.9 & 79.8 & - \\
1952 & 2.7 & 20.3 & 0.9 & 11.6 & 9.1 & 45.9 & 124.4 & 0.3 \\
1956 & 1.5 & 73.6 & 0.6 & 10.6 & 13.8 & 32.3 & 82.6 & - \\
1960 & 2.0 & 15.7 & 0.6 & 8.3 & 7.1 & 30.1 & 89.6 & 0.1 \\
1964 & 1.9 & 12.5 & 0.4 & 6.1 & 4.3 & 24.1 & 85.7 & - \\
1968 & 1.7 & 9.9 & 1.3 & 5.1 & 2.4 & 25.4 & 92.6 & - \\
1972 & 1.9 & 47.4 & 0.8 & 9.7 & 6.0 & 34.4 & 100.2 & 0.2 \\
$977 / 80^{*}$ & 1.8 & 19.8 & 1.3 & 8.6 & 7.5 & 32.5 & 82.6 & 0.2 \\
$982 / 84^{*}$ & 1.9 & 23.6 & 0.8 & 10.0 & 11.8 & 32.4 & 79.2 & 0.1 \\
$985 / 89^{*}$ & 2.9 & 20.0 & 2.5 & 16.5 & 8.7 & 46.1 & 71.8 & - \\
\hline
\end{tabular}

* Narrow rings analyzed simultaneously by single irradiation. 
Tree S-01

\begin{tabular}{rrrrrrrrr}
\hline YEAR & S1 & $\mathbf{P}$ & $\mathbf{S}$ & $\mathbf{C 1}$ & $\mathbf{K}$ & $\mathbf{C a}$ & $\mathbf{T 1}$ & $\mathbf{C r}$ \\
\hline 1976 & 108.1 & 223.6 & 439.3 & 108.0 & 3,860 & 1,780 & 13.7 & 1.0 \\
1982 & 134.6 & 233.3 & 425.2 & 118.7 & 3,540 & 1,500 & 22.2 & 0.4 \\
1987 & 74.1 & 391.4 & 401.9 & 170.9 & 3,050 & 1,120 & 7.9 & 0.6 \\
1989 & 96.0 & $1,410.0$ & 411.1 & 92.7 & 3,300 & 1,490 & 8.7 & 0.2 \\
1990 & 245.0 & $2,450.0$ & 527.2 & 193.0 & 5,930 & 1,400 & 8.9 & 3.4
\end{tabular}

cont.

\begin{tabular}{rrrrrrrrr}
\hline YEAR & Mn & Fe & Ni & Cu & Zn & Sr & Ba & Pb \\
\hline 1976 & 74.4 & 70.8 & 0.9 & 8.6 & 8.6 & 21.2 & 40.9 & 0.7 \\
1982 & 40.2 & 125.0 & 0.9 & 3.9 & 13.1 & 13.9 & 21.1 & 0.6 \\
1987 & 25.4 & 79.1 & 0.7 & 3.4 & 5.4 & 11.3 & 16.2 & 0.1 \\
1989 & 40.0 & 42.6 & 0.7 & 4.6 & 6.6 & 14.2 & 21.9 & 0.6 \\
1990 & 38.5 & 113.4 & 3.1 & 6.1 & 7.9 & 14.7 & 16.2 & 0.6 \\
\hline
\end{tabular}

Tree S-02

\begin{tabular}{rrrrrrrrr}
\hline YEAR & Si & $\mathbf{P}$ & $\mathbf{S}$ & $\mathbf{C l}$ & $\mathbf{K}$ & $\mathbf{C a}$ & $\mathbf{T} \mathbf{C}$ & $\mathbf{C r}$ \\
\hline 1968 & 80.8 & 28.0 & 453.8 & 28.5 & 4,621 & 1,601 & 3.3 & 1.1 \\
1972 & 74.3 & 43.9 & 589.8 & 21.5 & 5,314 & 1,547 & 3.2 & 0.5 \\
1976 & 191.4 & 487.3 & 399.5 & 59.6 & 2,490 & 1,085 & 10.3 & 26.4 \\
1978 & 138.8 & 254.7 & 305.3 & 177.4 & 1,644 & 1,032 & 5.2 & 0.7 \\
1980 & 74.3 & 607.6 & 425.7 & 74.5 & 2,550 & 1,760 & 3.5 & 4.5 \\
1982 & 93.3 & $1,423.0$ & 752.4 & 70.5 & 5,568 & 4,681 & 5.3 & 0.8 \\
$85 / 89^{*}$ & 152.1 & $1,470.0$ & 739.9 & 116.7 & 4,050 & 2,330 & 7.4 & 6.7
\end{tabular}
cont .

\begin{tabular}{rrrrrrrrr}
\hline YEAR & Mn & Fe & Ni & Cu & Zn & Sr & Ba & Pb \\
\hline 1968 & 24.4 & 62.0 & 1.2 & 15.8 & 5.3 & 24.5 & 6.3 & 1.8 \\
1972 & 26.5 & 60.4 & 1.2 & 6.0 & 8.1 & 21.1 & 53.1 & 0.8 \\
1976 & 29.0 & $1,290.0$ & 7.5 & 8.5 & 9.7 & 15.2 & 12.6 & 1.2 \\
1978 & 12.8 & 82.0 & 0.8 & 3.8 & 4.6 & 13.8 & 26.5 & 1.2 \\
1980 & 29.7 & 159.8 & 3.2 & 5.6 & 8.2 & 30.3 & 50.0 & 1.2 \\
1982 & 36.2 & 182.4 & 2.6 & 8.3 & 9.5 & 58.6 & 61.8 & 1.0 \\
$1985 / 89^{*}$ & 21.5 & 505.9 & 3.2 & 6.5 & 30.9 & 24.1 & 29.4 & 0.6
\end{tabular}

* Narrow rings analyzed simultaneously by single irradiation. 


\begin{tabular}{lrrrrrrrr}
\hline YEAR & Si & $\mathbf{P}$ & $\mathbf{S}$ & $\mathbf{C 1}$ & $\mathbf{K}$ & $\mathbf{C a}$ & $\mathbf{T i}$ & $\mathbf{C r}$ \\
\hline 1968 & 95.2 & 96.0 & 321.2 & 23.9 & 2,720 & 4,964 & 3.4 & - \\
1972 & 140.3 & 111.4 & 368.8 & 125.6 & 2,131 & 2,244 & 6.2 & 0.3 \\
1976 & 152.0 & 181.9 & 308.2 & 185.2 & 3,160 & 1,400 & 4.2 & - \\
1978 & 140.1 & 100.0 & 265.1 & 163.1 & 1,786 & 1,683 & 28.2 & - \\
1980 & 180.5 & 157.6 & 290.0 & 191.4 & 2,760 & 1,922 & 5.7 & - \\
1982 & 156.8 & 192.8 & 264.6 & 173.1 & 2,720 & 1,572 & 5.8 & - \\
1984 & 168.3 & 330.0 & 253.7 & 214.3 & 2,976 & 1,834 & 51.1 & 0.7 \\
1987 & 147.2 & 604.7 & 246.1 & 173.5 & 2,650 & 1,620 & 4.0 & - \\
1989 & 162.6 & 986.3 & 262.4 & 518.3 & 2,749 & 1,619 & 6.8 & 1.4 \\
1990 & 172.4 & $1,087.0$ & 247.3 & 197.1 & 2,446 & 1,721 & 5.1 &.-
\end{tabular}

cont.

\begin{tabular}{lrrrrrrrr}
\hline YEAR & Mn & Fe & Ni & Cu & Zn & Sr & Ba & Pb \\
\hline 1968 & 90.6 & 8.9 & 0.5 & 16.9 & 11.2 & 61.0 & 132.3 &.- \\
1972 & 42.6 & 38.4 & 1.4 & 14.5 & 16.0 & 24.9 & 53.0 & - \\
1976 & 29.8 & 27.8 & 1.8 & 16.5 & 11.5 & 15.3 & 40.5 & 0.4 \\
1978 & 38.9 & 21.2 & 1.8 & 9.1 & 6.9 & 20.6 & 49.0 & 0.2 \\
1980 & 45.3 & 27.5 & 1.2 & 8.3 & 16.6 & 22.2 & 50.7 & 0.2 \\
1982 & 29.8 & 38.9 & 1.1 & 7.8 & 16.1 & 19.1 & 44.2 & 0.5 \\
1984 & 54.6 & 25.3 & 1.2 & 5.9 & 7.4 & 20.1 & 49.3 & 0.3 \\
1987 & 29.0 & 26.5 & 0.8 & 4.9 & 7.1 & 18.2 & 34.9 & - \\
1989 & 42.1 & 155.3 & 3.0 & 10.9 & 9.3 & 26.8 & 31.0 & 0.4 \\
1990 & 40.2 & 50.9 & 1.3 & 6.4 & 6.0 & 21.9 & 35.9 & 0.2 \\
\hline
\end{tabular}


Tree SM-01

\begin{tabular}{rrrrrrrrr}
\hline YEAR & Si & $\mathbf{P}$ & $\mathbf{S}$ & $\mathbf{C 1}$ & $\mathbf{K}$ & $\mathbf{C a}$ & $\mathbf{T 1}$ & $\mathbf{C r}$ \\
\hline 1964 & 150.0 & 106.8 & 121.6 & 38.8 & 671 & 2,533 & 9.2 & - \\
1968 & 34.0 & 41.3 & 87.2 & 18.9 & 440 & 1,698 & 3.4 & - \\
1972 & 57.3 & 157.5 & 120.0 & 91.1 & 1,743 & 1,785 & 5.0 & - \\
1976 & 107.1 & 189.7 & 118.5 & 87.4 & 1,314 & 3,077 & 1.4 & - \\
1978 & 114.5 & 124.2 & 95.5 & 98.4 & 1,016 & 1,051 & 8.5 & - \\
1980 & 95.8 & 162.0 & 92.5 & 99.1 & 1,707 & 1,383 & 6.8 & - \\
1982 & 74.9 & 102.0 & 81.3 & 96.9 & 1,096 & 1,017 & 6.1 & 5.1 \\
1984 & 92.6 & 148.9 & 91.8 & 67.2 & 1,207 & 1,159 & 6.1 & - \\
1987 & 116.9 & 189.4 & 121.1 & 59.1 & 1,487 & 1,094 & 4.9 & 3.0 \\
1989 & 89.7 & 126.1 & 101.4 & 55.4 & 1,030 & 834 & 4.9 & 1.1 \\
1990 & 62.2 & 245.7 & 136.2 & 89.2 & 1,847 & 1,005 & 3.4 & -
\end{tabular}

cont.

\begin{tabular}{rrrrrrrrr}
\hline YEAR & Mn & Fe & Ni & Cu & Zn & Sr & Ba & Pb \\
\hline 1964 & 149.3 & 19.0 & 0.3 & 6.5 & 53.7 & 28.1 & 31.8 & 0.7 \\
1968 & 106.3 & 9.5 & 0.3 & 3.4 & 25.0 & 24.0 & 21.7 & 0.1 \\
1972 & 87.3 & 18.4 & 0.7 & 5.8 & 37.1 & 29.2 & 18.2 & 0.3 \\
1976 & 209.7 & 23.6 & 1.0 & 3.5 & 30.1 & 32.1 & 32.0 & -- \\
1978 & 79.2 & 24.9 & 1.4 & 5.4 & 42.2 & 21.2 & 9.6 & - \\
1980 & 121.1 & 28.3 & 0.4 & 3.8 & 38.8 & 20.7 & 18.1 & - \\
1982 & 108.2 & 69.0 & 2.2 & 4.2 & 29.4 & 18.6 & 6.4 & 0.1 \\
1984 & 70.2 & 26.2 & 0.5 & 3.3 & 24.8 & 16.0 & 15.0 & 0.5 \\
1987 & 64.4 & 65.9 & 1.7 & 4.3 & 18.0 & 15.0 & 13.9 & 0.3 \\
1989 & 59.7 & 81.0 & 2.2 & 5.0 & 18.2 & 13.1 & 14.7 & - \\
1990 & 50.8 & 24.9 & 1.6 & 5.4 & 14.3 & 13.4 & 13.0 & 0.2 \\
\hline
\end{tabular}




\begin{tabular}{rrrrrrrrr}
\hline YEAR & Si & $\mathbf{P}$ & $\mathbf{S}$ & $\mathbf{C l}$ & $\mathbf{K}$ & $\mathbf{C a}$ & $\mathbf{T} 1$ & $\mathbf{C r}$ \\
\hline 1952 & 57.6 & 140.7 & 71.8 & 58.7 & 9,443 & 3,208 & 2.8 & $\ldots$ \\
1956 & 52.1 & 100.5 & 91.0 & 44.3 & 7,480 & 1,762 & 2.3 & 0.3 \\
1964 & 56.0 & 91.6 & 98.1 & 49.5 & 4,856 & 1,495 & 2.0 & 0.2 \\
1968 & 74.6 & 106.6 & 105.5 & 85.1 & 4,000 & 2,457 & 2.0 & 1.9 \\
1972 & 38.4 & 127.5 & 118.0 & 57.9 & 5,219 & 3,549 & 3.0 & 0.2 \\
1978 & 90.3 & 167.9 & 138.5 & 116.3 & 2,718 & 1,255 & 4.9 & 0.6 \\
1980 & 39.0 & 87.5 & 107.7 & 166.6 & 1,855 & 931 & 4.2 & $\ldots$ \\
1982 & 44.5 & 159.8 & 128.3 & 112.7 & 3,275 & 1,080 & 4.3 & 0.2 \\
1984 & 45.4 & 255.3 & 185.7 & 75.5 & 3,425 & 1,216 & 3.9 & $\ldots$ \\
1987 & 57.0 & 284.9 & 195.0 & 75.5 & 2,973 & 1,229 & 3.3 & $\ldots$ \\
1989 & -- & 248.6 & 145.1 & 63.4 & 2,453 & 968 & 2.7 & $\ldots$ \\
1990 & 43.4 & 744.4 & 239.1 & 98.9 & 4,233 & 1,015 & 7.8 & $\ldots$
\end{tabular}

cont.

\begin{tabular}{rrrrrrrrr}
\hline YEAR & Mn & Fe & Ni & Cu & Zn & Sr & Ba & Pb \\
\hline 1952 & 215.1 & 22.2 & 0.8 & 4.1 & 27.4 & 33.8 & 78.4 & 0.5 \\
1956 & 134.5 & 46.5 & 0.6 & 3.7 & 20.6 & 20.1 & 41.1 & $\ldots$ \\
1964 & 119.8 & 53.6 & 0.8 & 2.8 & 16.0 & 21.0 & 42.7 & -- \\
1968 & 222.7 & 119.2 & 1.9 & 4.2 & 34.2 & 33.3 & 86.2 & $\ldots$ \\
1972 & 344.9 & 61.2 & 1.1 & 6.6 & 23.1 & 41.7 & 116.7 & $\ldots$ \\
1978 & 87.8 & 60.0 & 0.7 & 3.2 & 19.6 & 17.0 & 41.3 &.- \\
1980 & 81.3 & 22.6 & 0.8 & 3.6 & 21.6 & 15.4 & 32.5 & $\ldots$ \\
1982 & 55.4 & 23.8 & 1.6 & 4.1 & 18.0 & 14.3 & 34.7 & $\ldots$ \\
1984 & 87.4 & 37.6 & 0.5 & 4.5 & 15.0 & 17.3 & 47.6 & $\ldots$ \\
1987 & 92.4 & 20.8 & 0.8 & 3.9 & 11.3 & 18.6 & 73.9 & $\ldots$ \\
1989 & 50.3 & 27.1 & 0.6 & 3.9 & 12.7 & 14.2 & 38.6 & $\ldots$ \\
1990 & 39.7 & 31.8 & 1.2 & 4.9 & 10.0 & 14.9 & 45.2 & $\ldots$ \\
\hline
\end{tabular}


Tree W0-01

\begin{tabular}{rrrrrrrrr}
\hline YEAR & Si & $\mathbf{P}$ & $\mathbf{S}$ & $\mathbf{C 1}$ & $\mathbf{K}$ & $\mathbf{C a}$ & $\mathbf{T} \mathbf{1}$ & $\mathbf{C r}$ \\
\hline 1972 & 82.5 & 40.7 & 155.8 & 52.5 & 2,070 & 905 & 7.9 & 1.4 \\
1978 & 106.0 & 52.4 & 158.5 & 56.6 & 2,360 & 1,120 & 6.6 & 0.3 \\
1982 & 148.1 & 79.3 & 174.1 & 47.0 & 2,310 & 937 & 8.2 & 1.6 \\
1987 & 78.6 & 171.6 & 128.5 & 34.9 & 3,330 & 955 & 5.3 & 2.4 \\
1989 & 54.3 & 261.8 & 213.0 & 29.0 & 2,850 & 768 & 2.9 & 0.7 \\
1990 & 73.2 & 547.2 & 290.0 & 34.6 & 2,390 & 694 & 2.9 & 1.4
\end{tabular}

cont.

\begin{tabular}{rrrrrrrrr}
\hline YEAR & Mn & Fe & N1 & Cu & Zn & Sr & Ba & Pb \\
\hline 1972 & 89.4 & 47.4 & 1.4 & 7.4 & 7.3 & 4.0 & 9.0 & 0.2 \\
1978 & 105.8 & 25.2 & 2.6 & 12.7 & 6.9 & 4.8 & 6.6 & 0.1 \\
1982 & 123.7 & 67.1 & 1.5 & 4.6 & 6.0 & 3.5 & 4.5 & 0.4 \\
1987 & 124.8 & 94.0 & 2.1 & 4.3 & 4.1 & 3.0 & 1.6 & - \\
1989 & 115.1 & 83.3 & 1.2 & 6.1 & 5.1 & 3.5 & 2.3 & 0.2 \\
1990 & 275.8 & 36.0 & 1.4 & 3.4 & 3.8 & 3.8 & 2.2 & 0.2 \\
\hline
\end{tabular}


H. Location BL-08

Tree A-01

\begin{tabular}{lrrrrrrrr}
\hline YEAR & S1 & P & S & C1 & K & Ca & Ti & Cr \\
\hline 1948 & 132.4 & 20.0 & 312.1 & 875.0 & 2,165 & 1,051 & 9.6 & 12.5 \\
1952 & 82.9 & 34.7 & 407.9 & 106.2 & 1,817 & 2,086 & 7.2 &.- \\
1956 & 119.6 & 73.3 & 408.5 & 181.9 & 1,540 & 792 & 6.4 &.- \\
1960 & 80.9 & 89.4 & 229.5 & 110.5 & 1,209 & 831 & 5.4 &.- \\
1964 & 105.8 & 77.4 & 204.6 & 91.0 & 1,054 & 921 & 4.1 & 0.8 \\
1968 & 94.4 & 66.0 & 188.4 & 125.3 & 999 & 1,019 & 7.6 & 0.6 \\
1972 & 86.4 & 120.2 & 272.2 & 143.5 & 1,700 & 1,290 & 5.7 &. \\
1976 & 122.4 & 173.0 & 287.6 & 69.9 & 1,837 & 1,155 & 2.6 & - \\
1978 & 102.2 & 94.5 & 179.9 & 133.5 & 1,051 & 935 & 4.1 & 1.5 \\
1980 & 89.3 & 122.5 & 214.7 & 141.0 & 1,495 & 995 & 4.7 & 1.9 \\
1982 & 66.7 & 95.2 & 148.3 & 94.3 & 1,455 & 804 & 3.9 & 1.4 \\
1984 & 116.0 & 176.9 & 244.9 & 144.9 & 2,698 & 1,693 & 2.6 & 2.0 \\
1987 & 76.4 & 128.4 & 137.7 & 137.5 & 1,275 & 802 & 3.6 & 0.6 \\
1989 & 121.4 & 120.9 & 131.9 & 215.3 & 695 & 631 & 6.0 & 1.5 \\
1990 & 135.7 & 243.4 & 174.8 & 405.9 & 934 & 737 & 5.8 & 2.3
\end{tabular}

cont.

\begin{tabular}{rrrrrrrrr}
\hline YEAR & Mn & Fe & Ni & Cu & Zn & Sr & Ba & Pb \\
\hline 1948 & 8.4 & 979.1 & 3.4 & 164.4 & 46.4 & 18.7 & 47.1 &.- \\
1952 & 2.7 & 60.7 & 2.5 & 288.2 & 52.6 & 55.8 & 212.3 & 0.2 \\
1956 & 0.9 & 27.1 & 1.1 & 220.2 & 26.1 & 16.6 & 75.5 & -- \\
1960 & 1.0 & 43.0 & 1.1 & 32.1 & 36.6 & 18.5 & 73.1 & -- \\
1964 & 2.3 & 140.2 & 1.5 & 31.9 & 28.8 & 17.7 & 70.0 & 0.2 \\
1968 & 2.8 & 94.6 & 1.7 & 37.0 & 25.3 & 22.3 & 72.2 & 0.5 \\
1972 & 2.0 & 19.1 & 1.3 & 38.6 & 14.3 & 19.6 & 60.0 &.- \\
1976 & 2.6 & 41.3 & 1.5 & 40.3 & 12.9 & 19.6 & 54.6 & 0.5 \\
1978 & 3.1 & 204.3 & 2.0 & 37.2 & 11.5 & 21.4 & 41.8 &.- \\
1980 & 6.5 & 379.3 & 2.6 & 47.9 & 19.0 & 22.1 & 46.0 & 0.9 \\
1982 & 6.3 & 141.4 & 1.5 & 20.3 & 7.5 & 15.1 & 40.6 & 0.4 \\
1984 & 12.1 & 147.9 & 2.5 & 28.8 & 11.5 & 35.7 & 99.0 & -- \\
1987 & 7.4 & 238.5 & 1.2 & 10.2 & 7.2 & 13.5 & 34.5 &.- \\
1989 & 5.7 & 216.2 & 1.4 & 9.0 & 8.0 & 12.5 & 31.3 & 0.5 \\
1990 & 7.4 & 400.1 & 1.9 & 9.4 & 8.2 & 11.9 & 27.2 & 0.4 \\
\hline
\end{tabular}




\begin{tabular}{lrrrrrrrr}
\hline YEAR & $\mathbf{S} 1$ & $\mathbf{P}$ & $\mathbf{S}$ & $\mathbf{C 1}$ & $\mathbf{K}$ & $\mathbf{C a}$ & $\mathbf{T} \mathbf{C}$ & $\mathbf{C r}$ \\
\hline 1948 & 124.5 & 96.5 & 442.7 & 89.4 & 2,968 & 2,556 & 2.7 & 0.3 \\
1952 & $\mathbf{8 6 . 6}$ & 42.5 & 272.1 & 44.0 & 1,472 & 1,553 & 3.1 & -- \\
1956 & 146.9 & 111.2 & 392.1 & 79.3 & 2,658 & 1,076 & 6.1 & 0.2 \\
1960 & 106.8 & 51.5 & 271.2 & 62.9 & 1,863 & 1,154 & 4.1 & -- \\
1964 & 125.1 & 172.1 & 447.7 & 68.5 & 4,110 & 1,935 & 2.8 & 0.2 \\
1968 & 135.5 & 194.7 & 432.9 & 85.6 & 3,364 & 1,623 & 3.4 & -- \\
1972 & 77.2 & 84.4 & 268.8 & 103.3 & 1,496 & 1,190 & 2.7 & - \\
1974 & 96.4 & 106.7 & 273.6 & 90.4 & 1,343 & 1,063 & 2.9 & 0.6 \\
1978 & 56.8 & 89.0 & 224.1 & 68.6 & 1,005 & 1,289 & 1.0 & 2.7 \\
1980 & 58.7 & 122.9 & 250.8 & 64.5 & 1,049 & 1,143 & -- & -- \\
1982 & 56.5 & 88.4 & 198.7 & 42.6 & 592 & $\mathbf{8 6 4}$ & 3.0 & - \\
1984 & 70.6 & 208.0 & 279.3 & 43.6 & 1,161 & 1,223 & 3.5 & 4.8 \\
1987 & 119.4 & 540.7 & 382.4 & 56.6 & 1,881 & 1,581 & 2.6 & 0.6 \\
1989 & 89.1 & 454.5 & 239.5 & 114.4 & 840 & 882 & 0.9 & 0.9 \\
1990 & 97.1 & 750.3 & 275.7 & 126.9 & 1,420 & $\mathbf{8 8 3}$ & 7.4 & 0.2
\end{tabular}

cont.

\begin{tabular}{rrrrrrrrr}
\hline YEAR & Mn & Fe & N1 & Cu & Zn & Sr & Ba & Pb \\
\hline 1948 & 111.3 & 20.7 & 0.9 & 12.5 & 5.3 & 29.0 & 58.6 & 0.4 \\
1952 & 49.7 & 18.3 & 0.7 & 6.7 & 3.1 & 28.9 & 81.2 & 0.3 \\
1956 & 36.7 & 23.5 & 2.1 & 6.2 & 5.0 & 18.7 & 52.8 & 1.9 \\
1960 & 36.8 & 21.7 & 1.2 & 6.9 & 4.2 & 21.3 & 42.2 & -- \\
1964 & 35.1 & 32.1 & 1.2 & 6.6 & 5.9 & 21.4 & 44.6 & 0.6 \\
1968 & 35.3 & 13.2 & 0.9 & 6.1 & 5.9 & 17.1 & 32.1 & 0.5 \\
1972 & 30.8 & 15.3 & 1.4 & 4.6 & 6.4 & 15.5 & 29.1 & 0.4 \\
1974 & 31.9 & 101.0 & 1.9 & 7.1 & 6.3 & 20.4 & 36.6 &.- \\
1978 & 43.7 & 31.7 & 1.2 & 6.2 & 6.8 & 26.4 & 40.2 & 0.3 \\
1980 & 48.2 & 33.3 & 0.8 & 5.3 & 4.7 & 22.2 & 40.1 & 0.2 \\
1982 & 41.2 & 13.0 & 0.7 & 4.3 & 4.3 & 17.2 & 34.5 & -- \\
1984 & 37.2 & 59.0 & 0.9 & 4.5 & 6.2 & 21.4 & 32.9 & 0.3 \\
1987 & 39.8 & 68.0 & 1.4 & 6.2 & 5.1 & 19.6 & 28.6 & 0.4 \\
1989 & 28.2 & 109.3 & 1.9 & 7.2 & 5.7 & 14.1 & 15.2 & 0.6 \\
1990 & 19.6 & 117.3 & 1.3 & 5.6 & 5.1 & 13.1 & 9.5 & 0.3 \\
\hline
\end{tabular}


Tree SM-01

\begin{tabular}{lrrrrrrrr}
\hline YEAR & Si & $\mathbf{P}$ & $\mathbf{S}$ & $\mathbf{C 1}$ & $\mathbf{K}$ & $\mathbf{C a}$ & T1 & Cr \\
\hline 1968 & 68.3 & 102.0 & 116.0 & 67.0 & 640 & 896 & 3.5 & - \\
1972 & 59.1 & 97.0 & 117.0 & 203.0 & 714 & 929 & 2.3 & 0.4 \\
1976 & 72.4 & 145.0 & 131.0 & 109.0 & 1,754 & 1,268 & 3.5 & 1.2 \\
1978 & 100.8 & 161.0 & 158.0 & 174.0 & 1,704 & 1,155 & 4.2 & 0.6 \\
1980 & 96.6 & 121.0 & 131.0 & 205.0 & 1,702 & 850 & 4.1 & 0.2 \\
1982 & 72.6 & 141.0 & 133.0 & 295.0 & 2,057 & 1,078 & 4.0 & 1.9 \\
1984 & 84.4 & 134.0 & 123.0 & 295.0 & 1,508 & 734 & 3.3 & 4.5 \\
1987 & 96.4 & 225.0 & 144.0 & 363.0 & 2,546 & 749 & 3.1 & 2.1 \\
1989 & 98.6 & 200.0 & 124.0 & 378.0 & 2,071 & 705 & 4.7 & 6.9 \\
1990 & 96.8 & 230.0 & 150.0 & 501.0 & 2,147 & 713 & 6.2 & 9.4
\end{tabular}

cont

\begin{tabular}{rrrrrrrrr}
\hline YEAR & Mn & Fe & Ni & Cu & Zn & Sr & Ba & Pb \\
\hline 1968 & 78.1 & 18.0 & 1.1 & 15.4 & 21.0 & 12.4 & 27.3 & 0.4 \\
1972 & 84.4 & 31.0 & 1.6 & 3.2 & 19.0 & 13.3 & 26.8 & 0.1 \\
1976 & 87.1 & 87.0 & 0.9 & 3.1 & 21.7 & 17.6 & 45.6 & 0.5 \\
1978 & 94.8 & 139.0 & 1.1 & 6.6 & 40.1 & 19.4 & 46.6 & 0.2 \\
1980 & 41.6 & 86.0 & 0.6 & 2.9 & 17.3 & 9.7 & 26.2 & -- \\
1982 & 51.1 & 151.0 & 1.4 & 5.3 & 22.4 & 15.0 & 29.4 & 0.3 \\
1984 & 43.1 & 426.0 & 2.4 & 9.4 & 18.9 & 13.0 & 16.7 & - \\
1987 & 25.1 & 158.0 & 1.4 & 8.9 & 13.9 & 9.4 & 17.4 & - \\
1989 & 26.0 & 554.0 & 3.2 & 26.5 & 20.3 & 10.1 & 10.0 & 0.4 \\
1990 & 39.0 & 802.0 & 4.4 & 37.8 & 23.8 & 10.4 & 11.5 & -- \\
\hline
\end{tabular}


Tree wo-1

\begin{tabular}{lrrrrrrrr}
\hline YEAR & S1 & $\mathbf{P}$ & $\mathbf{S}$ & $\mathbf{C 1}$ & $\mathbf{K}$ & $\mathbf{C a}$ & $\mathrm{T} 1$ & $\mathbf{C r}$ \\
\hline 1960 & 43.1 & 37.2 & 111.4 & 90.4 & 845 & 530 & 2.6 & 0.1 \\
1964 & 102.6 & 48.0 & 149.9 & 227.4 & 1,618 & 956 & 5.0 & 0.9 \\
1968 & 69.5 & 58.4 & 125.0 & 122.5 & 1,257 & 927 & 0.7 & 0.8 \\
1972 & 56.0 & 28.8 & 105.5 & 103.0 & 1,449 & 1,135 & 1.7 & 0.6 \\
1976 & 55.7 & 38.0 & 125.2 & 152.7 & 1,256 & 992 & 1.2 & 0.3 \\
1978 & 52.2 & 82.9 & 110.1 & 103.2 & 3,154 & 833 & 2.6 & 0.3 \\
1980 & 94.1 & 133.9 & 135.1 & 283.0 & 4,049 & 1,364 & 3.4 & 1.8 \\
1982 & 28.2 & 140.8 & 115.6 & 322.7 & 3,829 & 1,006 & 1.6 & 0.5 \\
1984 & 37.4 & 106.4 & 129.3 & 163.9 & 2,093 & 1,400 & 1.4 & 0.1 \\
1987 & 49.6 & 152.5 & 147.6 & 82.1 & 1,545 & 1,824 & 4.2 & 1.5 \\
1989 & 77.7 & 134.4 & 151.0 & 63.5 & 1,198 & 1,766 & 23.1 & 1.5 \\
1990 & 89.9 & 321.2 & 228.8 & 107.6 & 1,880 & 1,282 & 22.1 & 2.6
\end{tabular}

cont.

\begin{tabular}{rrrrrrrrr}
\hline YEAR & In & Fe & NI & Cu & Zn & Sr & Ba & Pb \\
\hline 1960 & 150.3 & 29.3 & 4.2 & 3.4 & 9.3 & 4.9 & 11.6 &.- \\
1964 & 213.5 & 122.3 & 8.6 & 6.9 & 23.9 & 9.2 & 21.7 & 0.5 \\
1968 & 214.4 & 124.0 & 3.8 & 4.0 & 15.0 & 8.2 & 12.5 &.- \\
1972 & 186.4 & 72.0 & 3.8 & 3.3 & 7.7 & 7.1 & 11.8 & 0.1 \\
1976 & 161.6 & 55.8 & 2.8 & 3.3 & 9.5 & 6.7 & 16.3 & 0.1 \\
1978 & 180.6 & 72.3 & 3.1 & 3.0 & 6.5 & 6.5 & 8.4 & 0.2 \\
1980 & 217.3 & 150.1 & 6.0 & 7.2 & 12.1 & 9.1 & 14.5 & 0.7 \\
1982 & 179.5 & 70.8 & 6.0 & 4.5 & 11.7 & 6.8 & 11.2 & 0.6 \\
1984 & 209.3 & 82.9 & 5.0 & 3.1 & 9.1 & 10.2 & 7.6 &.- \\
1987 & 169.1 & 216.5 & 5.7 & 6.1 & 12.4 & 12.4 & 5.2 &.- \\
1989 & 166.6 & 204.3 & 5.3 & 5.9 & 10.7 & 10.6 & 3.5 & 0.2 \\
1990 & 168.3 & 278.3 & 6.5 & 6.1 & 14.3 & 8.5 & 5.6 & 0.3 \\
\hline
\end{tabular}


I. Location BL-09

Tree S-01

\begin{tabular}{lrrrrrrrr}
\hline YEAR & Si & $\mathbf{P}$ & $\mathbf{S}$ & $\mathbf{C 1}$ & $\mathbf{K}$ & $\mathbf{C a}$ & Ti & Cr \\
\hline 1976 & 69.1 & 258.8 & 635.4 & 43.5 & 3,170 & 2,040 & 6.9 & 2.5 \\
1982 & 58.7 & 301.7 & 665.2 & 48.7 & 3,610 & 2,380 & 5.8 & 0.8 \\
1987 & 75.2 & 836.5 & 545.2 & 32.9 & 2,850 & 1,980 & 3.7 & 0.8 \\
1989 & 26.9 & 363.0 & 345.4 & 132.3 & 1,620 & 1,820 & 2.0 & 1.3 \\
1990 & 69.7 & 645.6 & 318.5 & 222.5 & 1,990 & 1,360 & 1.4 & $\mathbf{8 . 5}$
\end{tabular}

cont.

\begin{tabular}{rrrrrrrrr}
\hline YEAR & Mn & Fe & Ni & Cu & Zn & Sr & Ba & Pb \\
\hline 1976 & 11.6 & 178.8 & 1.0 & 6.5 & 6.3 & 16.9 & 15.7 & 4.3 \\
1982 & 12.2 & 58.8 & 0.8 & 5.5 & 4.1 & 20.5 & 18.7 & 0.3 \\
1987 & 25.3 & 76.3 & 0.8 & 5.2 & 4.9 & 16.7 & 10.9 & 0.7 \\
1989 & 10.6 & 138.1 & 0.8 & 7.2 & 11.0 & 17.6 & 3.9 & 0.5 \\
1990 & 15.5 & 541.1 & 2.3 & 8.8 & 6.7 & 11.4 & -- & 0.3 \\
\hline
\end{tabular}


Tree SM-01

\begin{tabular}{rrrrrrrrr}
\hline YEAR & Si & $\mathbf{P}$ & $\mathbf{S}$ & $\mathbf{C 1}$ & $\mathbf{K}$ & $\mathbf{C a}$ & $\mathbf{T} \mathbf{C}$ & $\mathbf{C r}$ \\
\hline 1964 & 57.4 & 86.4 & 101.1 & 71.5 & 610 & 845 & 2.1 &.- \\
1968 & 25.5 & 63.7 & 84.9 & 48.9 & 771 & 887 & 0.7 & 0.2 \\
1972 & 93.3 & 176.8 & 174.9 & 58.6 & 2,249 & 1,959 & 4.7 & 0.6 \\
1976 & 54.6 & 139.5 & 118.6 & 37.4 & 2,190 & 1,193 & 1.4 &.- \\
1978 & 51.3 & 159.1 & 108.8 & 31.6 & 2,176 & 1,063 & 2.4 & - \\
1980 & 64.5 & 167.4 & 149.9 & 69.8 & 2,378 & 1,428 & 5.2 & 0.2 \\
1982 & 70.9 & 163.8 & 120.3 & 47.0 & 2,055 & 938 & 1.4 & - \\
1984 & 86.7 & 216.8 & 149.8 & 76.0 & 3,058 & 1,298 & 7.0 &.- \\
1987 & 34.8 & 158.1 & 111.0 & 71.2 & 1,664 & 655 & 2.4 & 1.2 \\
1989 & 52.0 & 316.0 & 218.0 & 47.4 & 1,921 & 691 & 1.6 & 0.8 \\
1990 & 64.1 & 245.7 & 219.7 & 66.5 & 1,333 & 515 & 2.7 & 1.5
\end{tabular}

cont.

\begin{tabular}{rrrrrrrrr}
\hline YEAR & Mn & Fe & N1 & Cu & Zn & Sr & Ba & Pb \\
\hline 1964 & 222.8 & 33.8 & 0.7 & 1.8 & 12.2 & 13.7 & 6.4 & 0.5 \\
1968 & 168.9 & 59.8 & 0.6 & 2.4 & 11.2 & 12.5 & 16.5 & 0.7 \\
1972 & 195.0 & 121.7 & 0.8 & 4.0 & 25.3 & 22.0 & 49.3 & 2.3 \\
1976 & 113.2 & 32.8 & 0.4 & 2.4 & 14.2 & 11.8 & 30.9 & 0.8 \\
1978 & 102.7 & 34.6 & 0.5 & 2.3 & 13.1 & 11.7 & 27.1 & 0.7 \\
1980 & 138.5 & 84.1 & 0.9 & 3.1 & 27.6 & 16.3 & 29.2 & 1.0 \\
1982 & 81.5 & 31.3 & 0.5 & 1.8 & 9.7 & 9.8 & 20.9 & 0.4 \\
1984 & 137.0 & 65.0 & 1.5 & 3.1 & 21.8 & 15.1 & 24.4 & 0.2 \\
1987 & 64.4 & 85.5 & 1.1 & 1.6 & 8.0 & 7.4 & 10.4 &.- \\
1989 & 67.1 & 44.3 & 0.8 & 2.3 & 9.5 & 7.5 & 12.5 & 0.2 \\
1990 & 61.4 & 72.9 & 1.3 & 2.6 & 9.2 & 6.5 & 9.0 &.- \\
\hline
\end{tabular}


Tree W-01

\begin{tabular}{lrrrrrrrr}
\hline YEAR & Si & $\mathbf{P}$ & $\mathbf{S}$ & $\mathbf{C 1}$ & $\mathbf{K}$ & $\mathbf{C a}$ & $\mathbf{T} \mathbf{H}$ & $\mathbf{C r}$ \\
\hline 1976 & -- & -- & 109.4 & 173.6 & 3,800 & 1,930 & 1.0 & 0.3 \\
1978 & 78.8 & 72.8 & 178.4 & 179.1 & 3,040 & 1,430 & 9.5 & 1.2 \\
1982 & 55.5 & 167.7 & 178.9 & 67.3 & 2,030 & 924 & 6.4 & 0.6 \\
1987 & 24.6 & 303.8 & 307.4 & 94.4 & 1,360 & 992 & 1.5 & 0.6 \\
1989 & 27.3 & 596.8 & 394.0 & 139.4 & 2,250 & 1,270 & 2.2 & 1.2 \\
1990 & -- & 735.5 & 334.8 & 125.3 & 2,780 & 1,310 & 5.1 & 2.6
\end{tabular}

cont.

\begin{tabular}{rrrrrrrrr}
\hline YEAR & Mn & Fe & N1 & Cu & Zn & Sr & Ba & Pb \\
\hline 1976 & 270.0 & 35.0 & 0.6 & 5.3 & 41.1 & 15.0 & -- & 0.4 \\
1978 & 213.2 & 69.4 & 0.8 & 3.9 & 51.4 & 12.7 & 1.9 & -- \\
1982 & 142.5 & 33.8 & 0.4 & 2.9 & 31.0 & 9.7 & 5.2 & 0.2 \\
1987 & 231.9 & 55.6 & 0.7 & 6.7 & 58.1 & 11.7 & 10.6 & 0.3 \\
1989 & 223.6 & 102.2 & 1.4 & 12.6 & 66.6 & 16.2 & 14.8 & -- \\
1990 & 179.2 & 168.0 & 1.4 & 15.0 & 48.4 & 13.9 & 8.7 & - \\
\hline
\end{tabular}

Tree W0-01

\begin{tabular}{lrrrrrrrr}
\hline YEAR & Si & $\mathbf{P}$ & $\mathbf{S}$ & $\mathbf{C 1}$ & $\mathbf{K}$ & $\mathbf{C a}$ & $\mathbf{T} \mathbf{C}$ & $\mathbf{C r}$ \\
\hline 1972 & -- & 61.3 & 136.3 & 57.8 & 3,670 & 844 & 2.3 & 6.1 \\
1976 & 35.4 & 134.1 & 155.6 & 54.9 & 4,590 & 1,340 & 0.7 & 0.8 \\
1978 & 34.2 & 132.4 & 127.3 & 36.9 & 3,820 & 1,040 & 1.4 & 0.8 \\
1982 & -- & 117.2 & 162.6 & 93.9 & 3,840 & 858 & 2.1 & 3.4 \\
1987 & 61.7 & 165.1 & 131.8 & 63.7 & 3,170 & 1,400 & 5.2 & 2.6 \\
1989 & 64.1 & 196.1 & 241.6 & 113.9 & 3,910 & 998 & 3.7 & 4.6 \\
1990 & 85.8 & 345.2 & 331.0 & 258.0 & 2,530 & 971 & 2.4 & 8.9
\end{tabular}

cont.

\begin{tabular}{rrrrrrrrr}
\hline YEAR & Mn & Fe & Ni & Cu & Zn & Sr & Ba & Pb \\
\hline 1972 & 93.5 & 237.7 & 3.1 & 4.1 & 6.6 & 6.4 & 9.0 & 0.3 \\
1976 & 119.2 & 77.3 & 2.2 & 3.1 & 4.9 & 9.5 & 16.0 & -- \\
1978 & 90.0 & 70.1 & 1.7 & 3.0 & 3.9 & 8.3 & 11.9 &.- \\
1982 & 79.2 & 284.1 & 2.1 & 4.6 & 6.4 & 6.9 & 13.7 & 0.2 \\
1987 & 31.0 & 318.5 & 1.8 & 4.7 & 5.4 & 10.8 & 7.9 & 0.9 \\
1989 & 41.9 & 534.9 & 1.8 & 10.1 & 9.9 & 7.5 & 5.9 & 0.8 \\
1990 & 75.4 & 862.3 & 2.3 & 13.5 & 13.4 & 8.5 & 13.8 & 2.1 \\
\hline
\end{tabular}

